\title{
Spent Nuclear Fuel Alternative Technology Risk Assessment
}

\author{
by \\ V. F. Perella \\ Westinghouse Savannah River Company \\ Savannah River Site \\ Aiken, South Carolina 29808 \\ E. W. Zimmerman
}

This paper was prepared in connection with work done under the above contract number with the U. S. Department of Energy. By acceptance of this paper, the publisher and/or recipient acknowledges the U.S. Government's right to retain a nonexclusive, royalty-free license in and to any copyright covering this paper, along with the right to reproduce and to authorize others to reproduce all or part of the copyrighted paper. 


\section{DISCLAIMER}

This report was prepared as an account of work sponsored by an agency of the United States Government. Neither the United States Government nor any agency thereof, nor any of their employees, makes any warranty, express or implied, or assumes any legal liability or responsibility for the accuracy, completeness, or usefulness of any information, apparatus, product or process disclosed, or represents that its use would not infringe privately owned rights. Reference herein to any specific commercial product, process or service by trade name, trademark, manufacturer, or otherwise does not necessarily constitute or imply its endorsement, recommendation, or favoring by the United States Government or any agency thereof. The views and opinions of authors expressed herein do not necessarily state or reflect those of the United States Government or any agency thereof.

This report has been reproduced directly from the best available copy.

Available for sale to the public, in paper, from: U.S. Department of Commerce, National Technical Information Service, 5285 Port Royal Road, Springfield, VA 22161

phone: (800) 553-6847

fax: (703) 605-6900

email: orders@ntis.fedworld.gov

online ordering: http://www.ntis.gov/ordering.htm

Available electronically at http://www.doe.gov/bridge

Available for a processing fee to U.S. Department of Energy and its contractors, in paper, from: U.S. Department of Energy, Office of Scientific and Technical Information, P.O. Box 62, Oak Ridge, TN 37831-0062

phone: (865)576-8401

fax: (865)576-5728

email: reports@adonis.osti.gov 


\section{DISCLAIMER}

Portions of this document may be illegible in electronic image products. Images are produced from the best available original document. 
RECOADS ADMINISTRATION

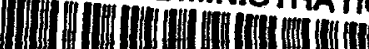

R0082039

\section{Spent Nuclear Fuel Alternative Technology}

\section{Risk Assessment (U)}
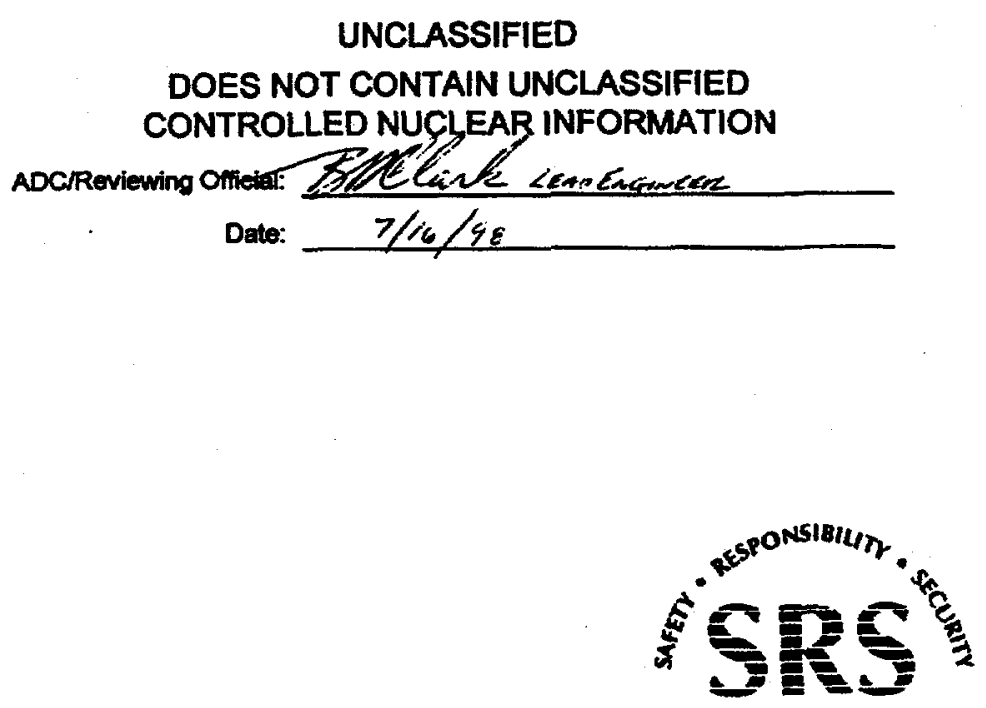
Spent Nuclear Fuel Alternative Technology

\section{Risk Assessment (U)}

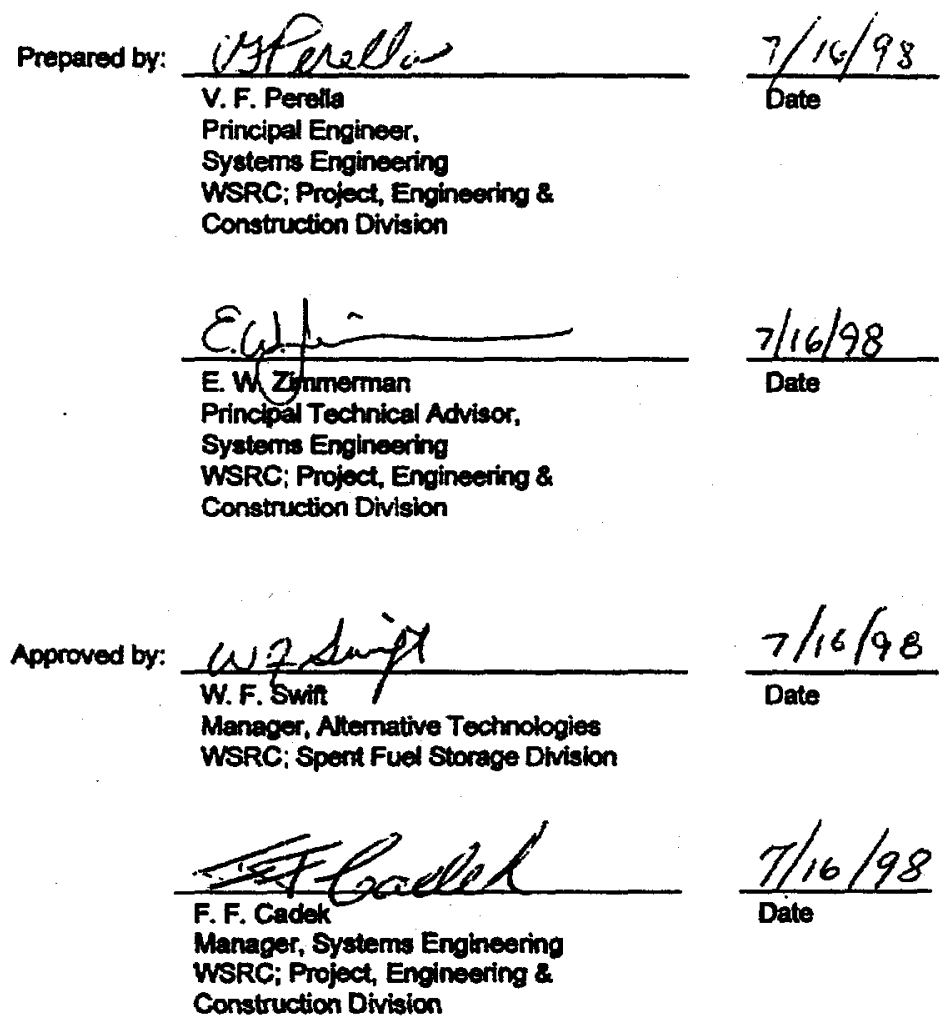




\section{TABLE OF CONTENTS}

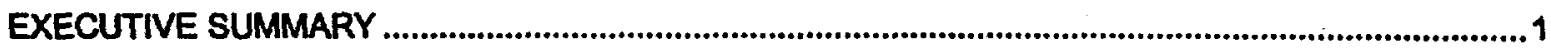

INTRODUCTION

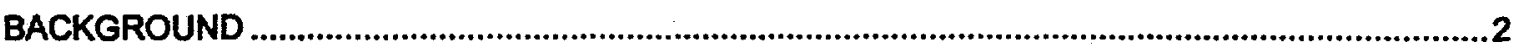

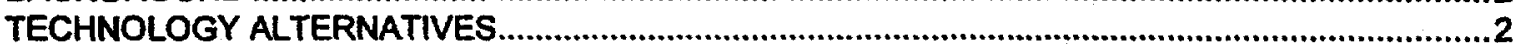

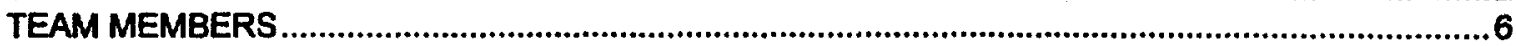

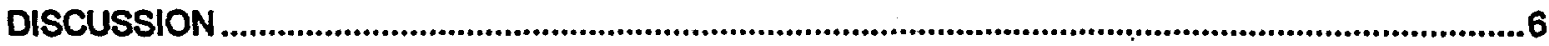

INITIATION OF TASK

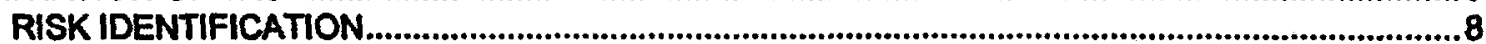

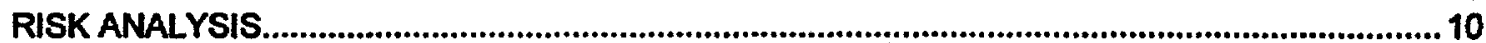

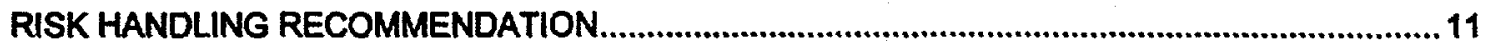

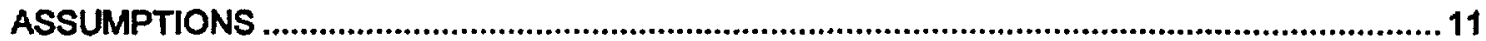

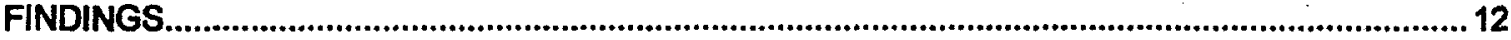

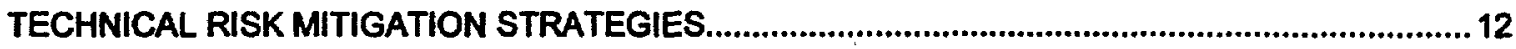

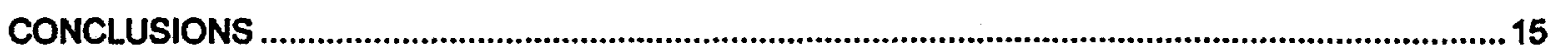

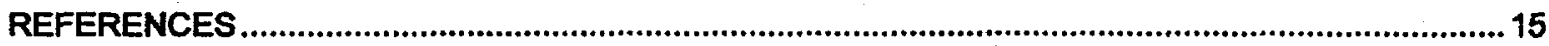

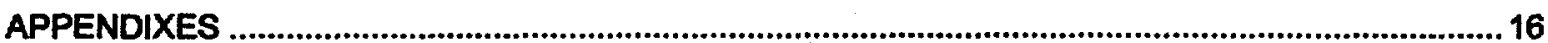




\section{LIST OF FIGURES}

Figure 1. Facility Process Flow Diagram, Direct Co-Disposal ....................................................................3

Figure 2. Facility Process Flow Diagram, Melt \& Dilute ..............................................................................5

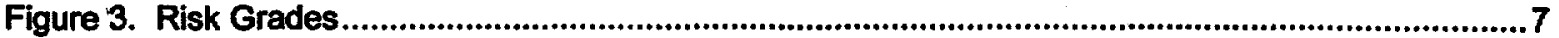

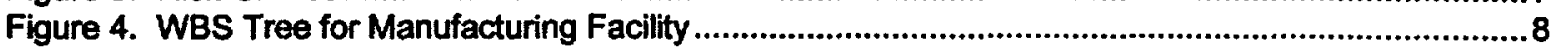

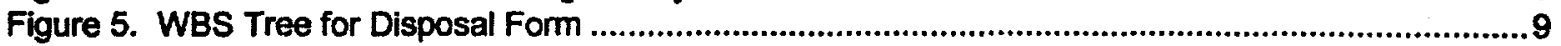

\section{LIST OF TABLES}

Table 1. Risk Assessment Summary. 


\section{LIST OF ACRONYMS}

$\begin{array}{ll}\text { ANL } & \text { Argonne National Laboratory } \\ \text { CFR } & \text { Code of Federal Regulations } \\ \text { DE } & \text { Design Engineering } \\ \text { DOE } & \text { Department of Energy } \\ \text { DOE-RW } & \text { Department of Energy, Office of Civilian Radioactive Waste Management } \\ \text { DWPF } & \text { Defense Waste Processing Facility } \\ \text { EBR } & \text { Experimental Breeder Reactor } \\ \text { HA } & \text { Handling Action } \\ \text { HEU } & \text { High Enriched Uranium } \\ \text { HLW } & \text { High Level Waste } \\ \text { LEU } & \text { Low Enriched Uranium } \\ \text { LLW } & \text { Low Level Waste } \\ \text { MGDS } & \text { Mined Geologic Disposal System } \\ \text { MTR } & \text { Materials \& Test Reactor } \\ \text { NWPA } & \text { Nuclear Waste Policy Act } \\ \text { PE\&CD } & \text { Projects, Engineering \& Construction Division } \\ \text { R\&D } & \text { Research \& Development } \\ \text { RAPP } & \text { Risk Assessment Program Plan } \\ \text { ROD } & \text { Record of Decision } \\ \text { RRTT } & \text { Research Reactor (Spent Nuclear Fuel) Task Team } \\ \text { SE } & \text { Systems Engineering } \\ \text { SFSD } & \text { Spent Fuel Storage Division } \\ \text { SNF } & \text { Spent Nuclear Fuel } \\ \text { SRS } & \text { Savannah River Site } \\ \text { SRTC } & \text { Savannah River Technology Center } \\ \text { TBD } & \text { To Be Determined } \\ \text { TSS } & \text { Transfer and Storage Services } \\ \text { U-AN } & \text { Uranium-Aluminum } \\ \text { WAC } & \text { (Mined Geologic Disposal System) Waste Acceptance Criteria } \\ \text { WBS } & \text { Work Breakdown Structure } \\ \text { WSRC } & \text { Westinghouse Savannah River Company } \\ & \end{array}$


This page intentionally left blank 


\section{EXECUTIVE SUMMARY}

A Research Reactor Spent Nuclear Fuel Task Team (RRTT) was chartered by the Department of Energy (DOE) Office of Spent Fuel Management with the responsibility to recommend a course of action leading to a final technology selection for the interim management and ultimate disposition of the foreign and domestic aluminum-based research reactor spent nuclear fuel (SNF) under DOE's jurisdiction. The RRTT evaluated eleven potential SNF management technologies and recommended that two technologies, Direct Co-Disposal and an isotopic dilution alternative, either Press \& Dilute or Melt \& Dilute, be developed in parallel'.

Based upon that recommendation, the Westinghouse Savannah River Company (WSRC), Spent Fuel Storage Division (SFSD), organized the SNF Alternative Technology Program to further develop the Direct Co-Disposal and Melt \& Dilute technologies and ultimately provide a WSRC recommendation to DOE for a preferred SNF alternative management technology. A technology risk assessment was conducted as a first step in this recommendation process to determine if either, or both, of the technologies posed significant risks that would make them unsultable for further development. This report provides the results of that technology risk assessment.

The risk assessment process involved the completion of the following three activities in accordance with the requirements of the Risk Assessment Program Plan, Transfer and Storage Services for AluminumBased Spent Nuclear Fuel ${ }^{2}$ :

1. Risk Identification - Identifying the risks for each SNF technology, for each Work Breakdown Structure (WBS) element;

2. Risk Analysis - Evaluating the identified risks (probability and consequences) and assessing them as High, Moderate, or Low, and,

3. Risk Handling Recommendation - Selecting a handling action for each risk (Mitigate, Avoid, Transfer, or Accept), and for a handling action of Mitigate, determining a mitigation strategy for each identified High and Moderate risk.

The SNF Alternative Technology Risk Assessment identified 24 active risks", of which only 5 were assessed as Moderate and 7 were assessed as High. All of the Moderate and two of the High risks were reduced to Low risks with success probabilities of $75 \%$ or greater, and 3 High risks were reduced to Moderate risks with success probabilities of $100 \%$ using mitigation strategies recommended by the assessment team. The remaining 2 High risks (one for each technology) address the possibility of existing repository-level performance requirements being redefined and imposed at the SNF disposalform-level by the Department of Energy, Office of Civilian Radioactive Waste Management (DOE-RW). While these risks were judged by the assessment team to be Very Unlikely, the potential impact of changes in repository requirements will be mitigated by SFSD's continuing dialog with DOE-RW and its Yucca Mountain repository managing and operating contractor.

Based upon the results of this assessment, it is the conclusion of the risk assessment team that the Melt \& Dilute and Direct Co-Disposal alternative technologies are both acceptable for further development provided mitigation strategies recommended by the team for Moderate and High risks are followed and tracked through completion by a project team. SFSD has committed to proceed with the risk management process throughout implementation of the Treatment and Storage Facility Project.

- See Table 1 on Pages 13 \& 14. 


\section{INTRODUCTION}

\section{BACKGROUND}

The Record of Decision for the Environmental Impact Statement on the Proposed Nuclear Weapons Nonproliferation Policy Concerning Foreign Research Reactor Spent Nuclear Fuel directed the Department of Energy (DOE) to implement alternative treatment and packaging technologies that could be utilized in place of conventional processing to achieve safe and cost effective interim storage and ultimate disposal of aluminum-based spent nuclear fuel (SNF). As a result, the DOE Office of Spent Fuel Management chartered the Research Reactor Spent Nuclear Fuel Task Team (RRTT) with the responsibility to recommend a course of action leading to a final technology selection for the interim management and ultimate disposition of the foreign and domestic aluminum-based research reactor SNF under DOE's jurisdiction.

The RRTT evaluated eleven potential SNF management fechnologies, ranging from direct disposal and isotopic dilution to advanced treatments such as plasma arc treatment and glass material oxidation and dissolution. Using a modified Kepner-Tregoe ${ }^{3}$ evaluation process, the RRTT recommended that two technologies, Direct Co-Disposal and an isotopic dilution alternative, either Press \& Dilute or Melt \& Dilute, be developed in parallel. The RRTT also recommended that an advanced technology, Electrometallurgy, although not directly developed for aluminum research SNF nor funded by the SNF program, be considered as a secondary and diverse backup.

Based on the recommendations of the RRTT report', WSRC onganized the SNF Altemative Technology Program to further develop the Direct Co-Disposal and Melt \& Dilute technologies ${ }^{b}$ and ultimately provide a WSRC recommendation to DOE for a preferred SNF altemative management technology. As a first step in this recommendation process, a technology risk assessment was conducted to determine if either, or both, of the technologies posed significant risks that would make them unsuitable for further development. This report provides the results of the technology risk assessment conducted in accordance with the requirements of the Risk Assessment Program Plan, Transfer and Storage Services for Aluminum-Based Spent Nuclear Fuel ${ }^{2}$.

\section{TECHNOLOGY ALTERNATIVES}

As noted above, only two technologies, Direct Co-Disposal and Melt \& Dilute, were considered in this risk assessment. A brief description of each of these technologies is provided below. Pre-conceptual design has been completed on both technologies4.

\section{Direct Co-Disposal (see Figure 1 on page $3^{\mathrm{C}}$ )}

In this technology, the SNF will be packaged intact in a canister that has a diameter of approximately seventeen inches and a length of approximately 120 inches. The canister of fuel will be vacuum dried and back-filled with helium. The fuel will be separated in the canister with a basket containing neutron absorber materials. Three to four baskets will be stacked within each canister. After the canister is back-filled and sealed, it will be temporarily stored at the Savannah River Site (SRS) in horizontal concrete storage modules.

\footnotetext{
- Press \& Dilute was not considered further because it was as costly as Melt \& Dilute and did not offer the isotopic dilution capabilities of Melt \& Dilute.

c Figure 8.5.2-1 from the Pre-conceptual Design Report reprinted here for information only.
} 

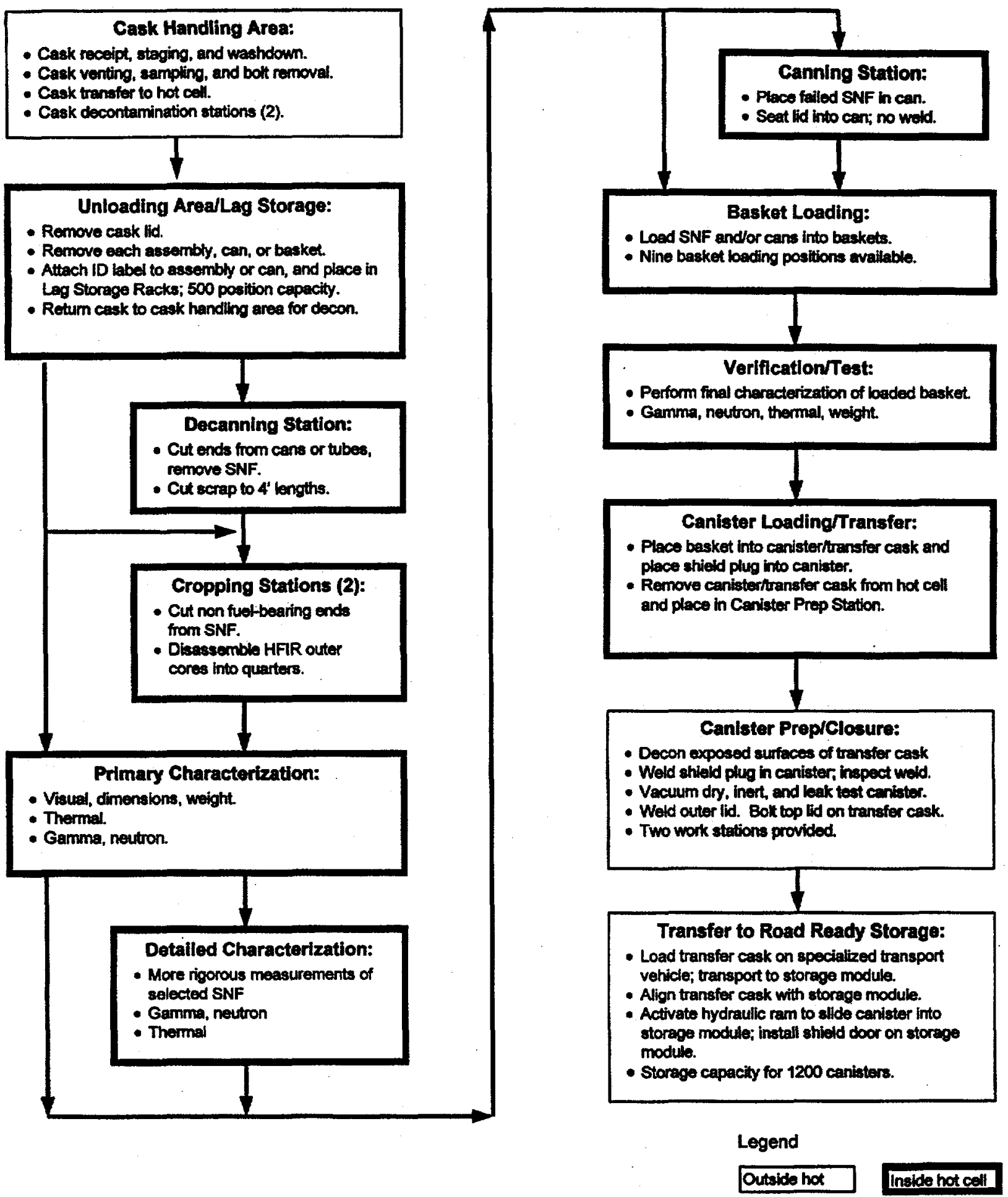

Figure 1. Facility Process Flow Dlagram, Direct Co-Dlsposal 
Ultimately, the canisters will be shipped to a federal Mined Geologic Disposal System (MGDS) repository for final disposal. There each of the SNF canisters will be placed inside a larger waste package containing five Defense Waste Processing Facility (DWPF) high level waste (HLW) canisters before being emplaced in the repository.

The Direct Co-Disposal alternative will require a separate powder metallurgy process to accommodate the disposition of the foreign research reactor target oxide materials listed in Table 5.2-2 of the RRTT report'. These materials could be combined at $30 \mathrm{wt} \%$ with aluminum powder (or higher if necessary to make a good compact), compressed to make $3^{\prime \prime}$ OD $\times 24^{\prime \prime}$ slugs, cold welded, loaded into the standard canister, filled with inert gas, welded, leak checked, and finally, interim-stored prior to shipment to the repository.

\section{Melt \& Dilute (see Figure 2 on page $5^{d}$ )}

In this technology, the SNF will be melted in a furnace, and depleted uranium and aluminum (as needed to control the metallurgy and process temperature) will be added to the melt in order to reduce the ${ }^{235} \mathrm{U}$ enrichment to below $20 \%$, the level required to be treated as low enriched uranium (LEU). If required, neutron absorber materials will also be added to the melt to minimize the potential for longterm criticality in the repository. The melt will be solidified and placed in a steel canister similar to that for the Direct Co-Disposal alternative. Several ingots may be stacked in each canister. The canister will then be back-filled with helium, sealed, and temporarily stored at SRS in horizontal concrete storage modules. Even though additional mass will be added to the disposal form during the melting process (in the form of aluminum and depleted uranium), the total volume required for the disposal forms will only be approximately one quarter of that required for Direct Co-Disposal. Like the Direct Co-Disposal alternative, the canisters will ultimately be shipped to a federal MGDS repository for final disposal with DWPF canisters.

The melting process will cause volatilization of some fission products. Those gases will be collected and processed onsite as either HLW or low level waste (LLW), with the exception of noble gases such as krypton which will be released to the facility stack.

\footnotetext{
- Figure 8.6.2-1 from the Pre-conceptual Design Report' reprinted here for information only.
} 


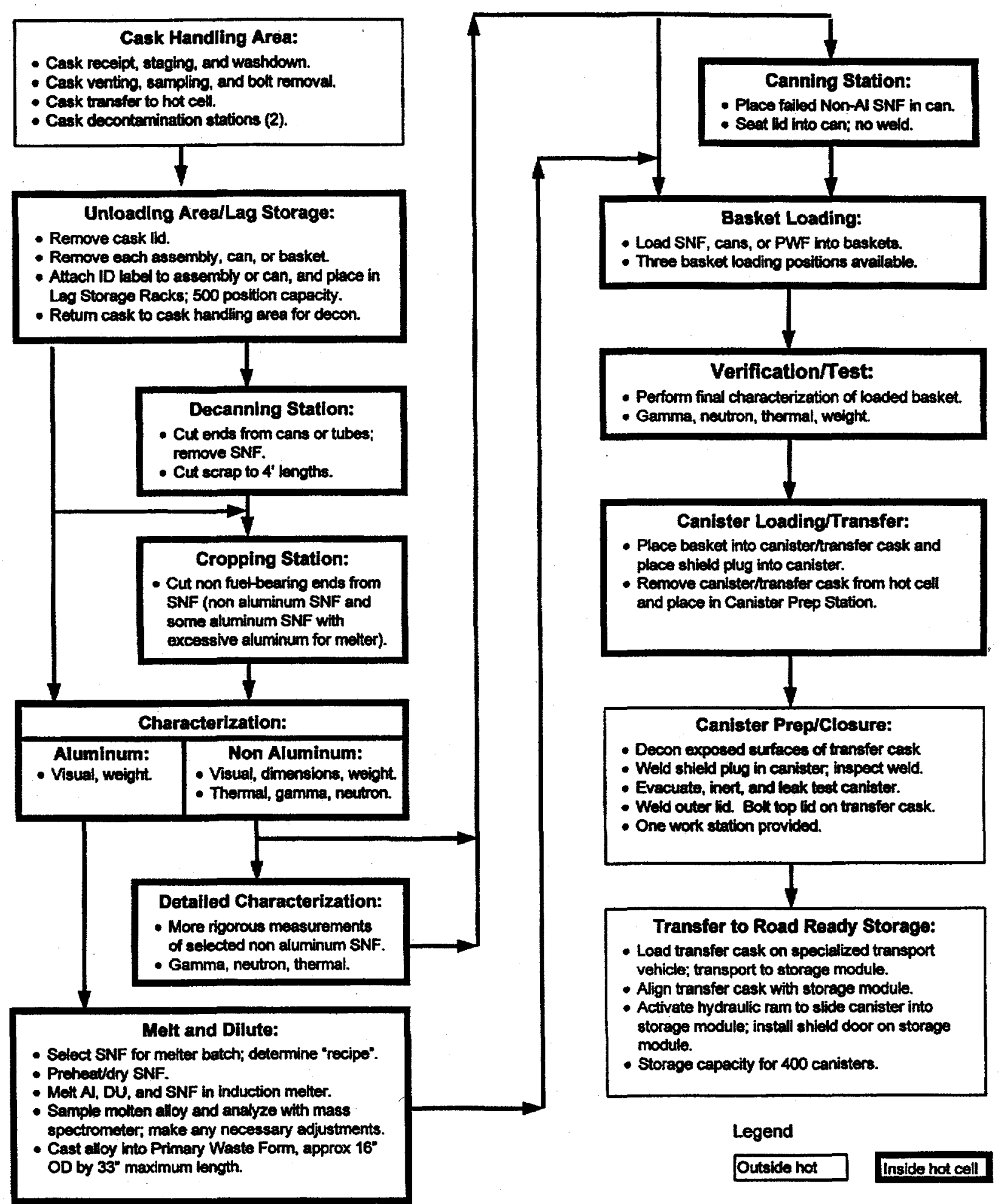

Figure 2. Facility Process Flow Dlagram, Melt \& Dilute 


\section{TEAM MEMBERS}

As directed by the SNF Risk Assessment Program Plan (RAPP)', the following team comprised of individuals from Spent Fuel Storage Division (SFSD), Savannah River Technology Center (SRTC), Project, Engineering \& Construction Division/Design Engineering (PE\&CD/DE), and Project, Engineering \& Construction Division/Systems Engineering (PE\&CD/SE), was convened to conduct the risk assessment.

\section{Name}

T. M. Adams

A. K. Brewer

J. M. Carter

J. Hurd

L. T. Lamm

L. W. Patrick

H. B. Peacock, Jr.

V. F. Perella

F. C. Rhode

W. F. Swift

D. W. Vinson

E. W. Zimmerman

\section{Division}

SRTC

SFSD

PE\&CD

PE\&CD

PE\&CD

PE\&CD

SRTC

PE\&CD

SFSD

SFSD

SRTC

PE\&CD

\section{Organization}

Materials Application \& Corrosion Technology

Spent Fuel Storage Engineering

Systems Engineering

Design Engineering

Design Engineering

Systems Engineering

Materials Application \& Corrosion Technology

Systems Engineering

Spent Fuel Storage Engineering

Spent Fuel Storage Engineering

Materials Technology

Systems Engineering

\section{DISCUSSION}

\section{INITIATION OF TASK}

In a series of five interactive meetings from $11 / 10 / 97$ to $12 / 9 / 97$, the team conducted a risk assessment for each of the two selected SNF technologies (Direct Co-Disposal and Melt \& Dilute) using the process identified in Section 3.0 of the SNF RAPP. Since this assessment was to include all project risks, the following eight facets of risk as listed in the RAPP were addressed in this assessment to the extent possible:

- Safety

- Environmental

- Technical Performance

- Logistics Support

- Disposition

- Programmatic

- Cost

- Schedule

As noted in the RAPP, the assessment process followed the method of E7 Manual Procedure 2.16, Technical Risk Analysis, with one exception. This exception involved the grading of risks as Low, Moderate, or High using a $3 \times 3$ probability versus consequence matrix, shown in Figure 3 . The E7 
Manual Procedure 2.16 prescribes the use of a risk factor equation that can result in many risks considered Low and Moderate by the risk assessment team falling into the High grade. The risk grading process used in this assessment emulates that of the technical community. The use of a matrix in grading risks is also one of the recommended methods in the Project Risk Analysis Guide? which is referenced by E11 Manual Procedure 2.62, Project Risk Analysis ${ }^{8}$.

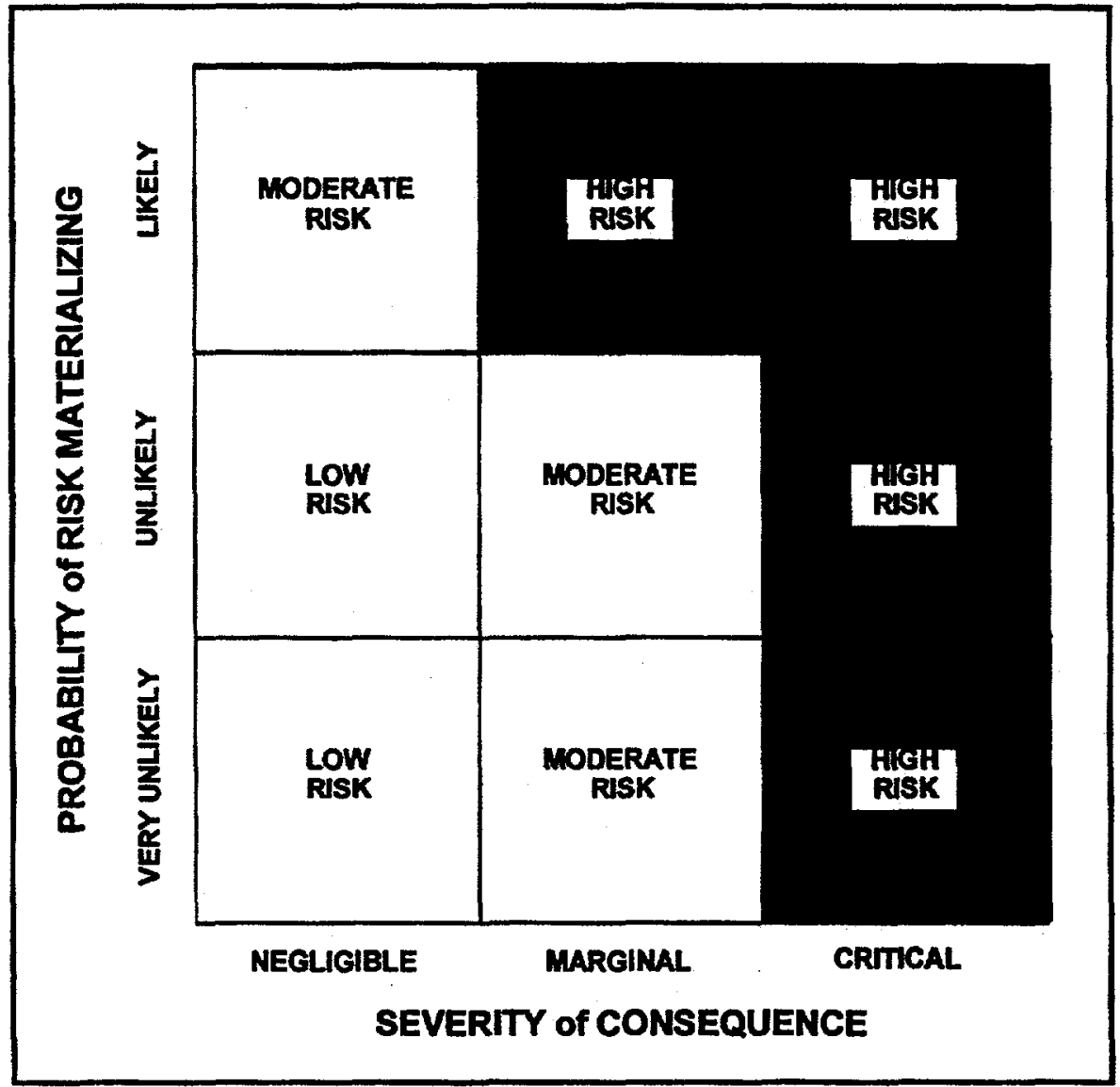

Figure 3. Risk Grades

The process used in this risk assessment involved the completion of the following three activities:

1. Risk Identification - Identifying the risks for each SNF technology, for each Work Breakdown Structure (WBS) element;

2. Risk Analysis - Evaluating the identified risks (probability and consequences) and assessing them as High, Moderate, or Low, and,

3. Risk Handling Recommendation - Selecting a handling action for each risk (Mitigate, Avoid, Transfer, or Accept), and for a handling action of Mitigate, determining a mitigation strategy for each identified High and Moderate risk.

- The $3 \times 3$ matrix is based upon a simplification of risk management categories shown in Figure 6.11 of Systems Engineering by Andrew P. Sage'. 


\section{RISK IDENTIFICATION}

To facilitate the identification of risks, separate WBS trees were created for each of the subject areas: Manufacturing Facility (or process) and Disposal Form (or product). The WBS tree for each subject area was comprised of functional areas that supported the specific subject area. For the Manufacturing Facility WBS tree (Figure 4), the X.1 Common Facilities functional areas were derived from Section 4.2 of the Transfer and Storage Services Pre-conceptual Design report", and the X.2 Process Facilities functional areas were derived from Sections 4.3 and 4.4 of that same report. Functional areas Y.1.1 through Y.1.5 of the Disposal Form WBS tree (Figure 5) concentrated on canister design issues, while the remaining functional areas (Y.1.6 through Y.1.12) focused on disposal form issues deemed important by the team.

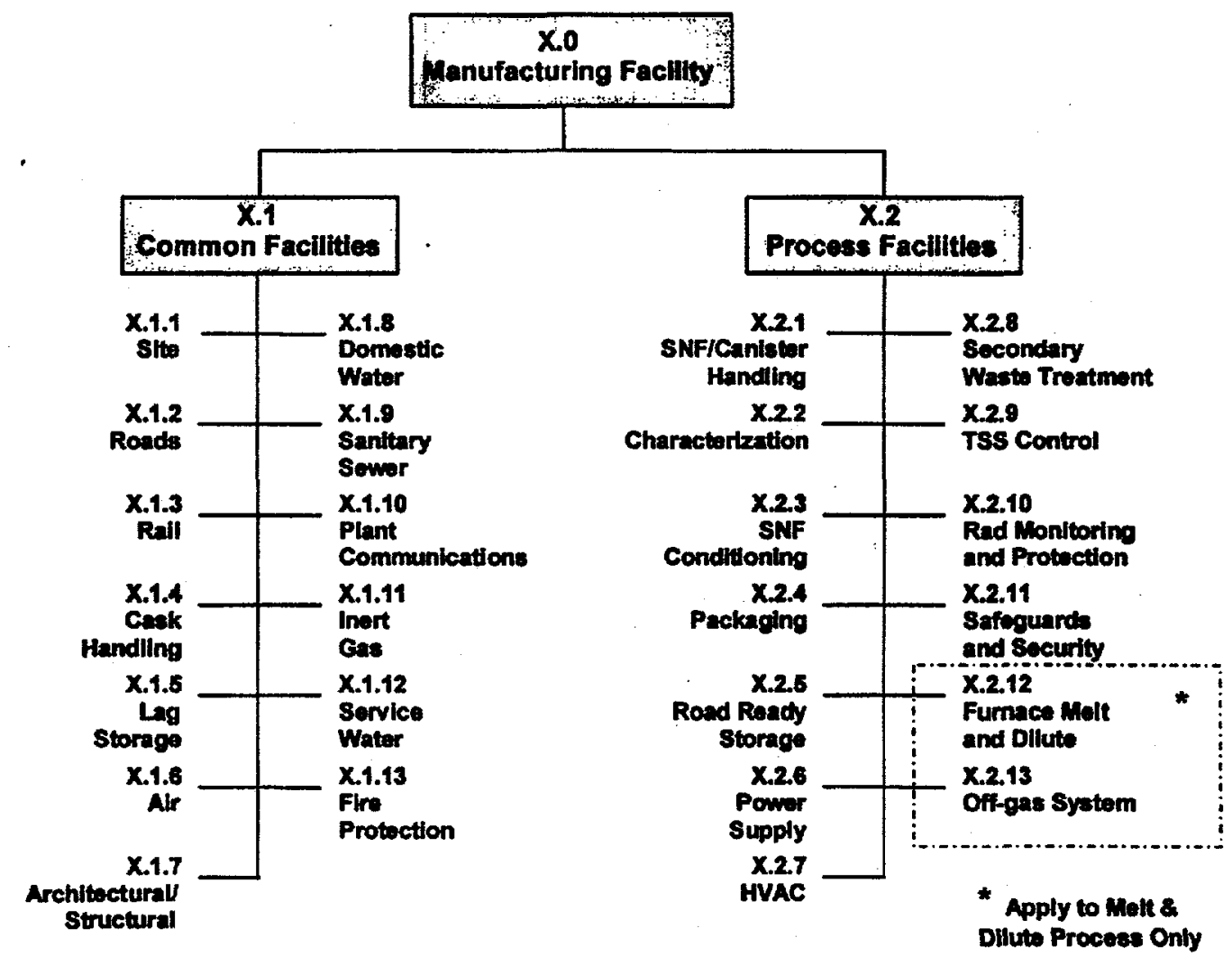

Figure 4. WBS Tree for Manufacturing Facility 
The team used each of the WBS trees to assist in the identification and documentation of risks for each of the functional areas, as appropriate. Candidate risks for each of the subject areas were identified by the team based upon the following:

- Review of technology reports and documents to identify the known risks and inconsistencies;

- Review and analysis of assumptions made for the two SNF technologies during the down-select process;

- Review of assumption, uncertainties, and problems found in technology development and engineering development programs;

- Review of simulations, models, and other studies/analyses for the two SNF technologies; and,

- Review of DOE risk identifiers for applicability to the two SNF technologies.

Documents utilized in the assessment process' are listed in the References beginning on Page 15.

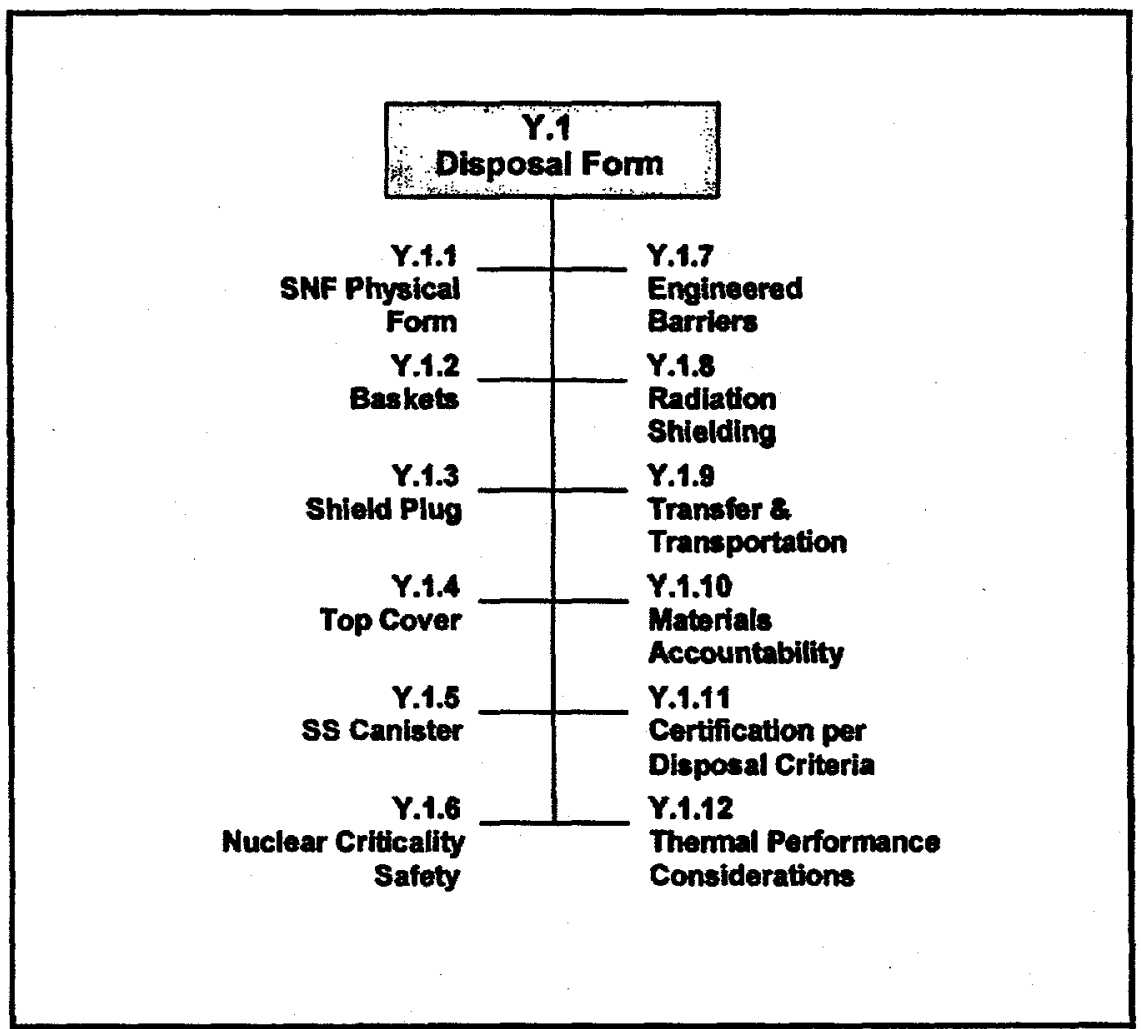

Figure 5. WBS Tree for Disposal Form

' References 1, 4,9, and 11 through 18. 
A SNF Risk Assessment database was created using guidelines provided in the RAPP to document each of the risks identified by the team. For each identified risk, the team provided the following initial information.

1. Statement of Risk - A brief, concise statement of the risk, indicating which WBS element or elements were vulnerable and the nature of the vulnerability.

2. Rational Basis for Risk - A brief rationale that makes clear what the impact will be if the risk materializes. This rationale was based upon either best engineering judgement or the results of technical analysis, if available.

\section{RISK ANALYSIS}

The team assigned a probability of occurrence and a severity of consequence grade for each of the identified risks documented in the database. These estimates of probability and consequence grades were also based upon either best engineering judgement or technical analysis results, if available, and utilized the following definitions.

1. Probability of Risk Materializing - The probability grade was designated to be Very Unlikely, Unlikely, or Likely as defined below.

Very Unlikely - Not expected to occur anytime in the life cycle of the project or its operating facilities. Estimated recurrence interval exceeds 10,000 years.

Unlikely - Not expected to occur in the life cycle of the project, and doubtful occurrence for its operating facilities. Estimated recurrence interval is 100 to 10,000 years.

Likely - Expected to occur sometime during the life cycle of the project or its operating facilities. Estimated recurrence interval is less than 100 years.

2. Severity of Consequence - The consequence grade was designated to be Negligible, Marginal, or Critical as defined below.

Negligible - Minor threat to cost, schedule, technical performance, environment or people. May require facility minor changes in operations or maintenance, with lost time extending to a few weeks but not months. May involve routine cleanup or first aid, but no redesign.

Marginal - Nominal threat to cost, schedule, technical performance, environment or people. May require minor redesign or repair or environmental remediation with an impact of more than $5 \%$ but less than $10 \%$ of project schedule and/or life cycle cost. Has potential for minor occupational injury requiring medical intervention.

Critical - Serious threat to cost, schedule, technical performance, environment or people. May prevent completing portions of the mission or cause failure to perform functions to meet requirements. May require major facility redesign or rebuilding, extensive environmental remediation or intensive medical care for life-threatening injury. Impacts will likely exceed $10 \%$ of project schedule and/or life cycle cost.

With probability and consequence grades defined, the team used the $3 \times 3$ probability versus consequence matrix shown in Figure 3 to assign a risk grade to each of the identified risks.

- See Appendix A. 


\section{RISK HANDLING RECOMMENDATION}

According to the RAPP, each unacceptable risk must have a recommended handling action (HA) to make it acceptable. Consequently, the Moderate and High grade risks were evaluated against each of the following four possible strategies for risk handling before selecting the preferred strategy.

1. Mitigate the Risk - The project can use simulations (virtual prototypes), analytical models or research and development to test-validate assumptions or reduce uncertainties that underpin a risk.

2. Avoid the Risk - The project can simply avoid the risk by choosing another design or another technology or both, whichever is causing the risk.

3. Transfer the Risk - The project can transfer the risk to another of its WBS element or, in some unusual cases, transfer it to an insurance company. Insured risks were not a consideration for the SNF risk assessment.

4. Accept the Risk - The project can accept the risk and do nothing else except to monitor for early triggers or indicators that the risk will strike the project. Upon detecting a trigger, the project will take preplanned evasive action.

Risk handling strategies were selected by the team for each of the Moderate and High grade risks and documented in the database. Each of the handling action recommendations were to include:

- The basis for the recommendation;

- A rough estimate of the cost, schedule, facilities and manpower needed to accomplish the handling action;

- An estimate of the grade of the risk after the recommended handling action is complete (e.g., the reduction in risk resulting from the handling action);

- Closure criteria, making clear what results must be accomplished for success;

- The probability of success for the handling action.

\section{ASSUMPTIONS}

The team used the following general assumptions in conducting the risk assessment.

1. All aluminum-clad SNF types and materials listed in Table 5.2-1 of the Research Reactor SNF Task Team Report' will be processed in the SRS canyons as recommended, and consequently, they were not considered in the technology risk assessment.

2. Target materials in powdered form to be received under FRR EIS (Canada, Belgium, Argentina, and Indonesia) listed in Table 5.2-2 of the Research Reactor SNF Task Team Report' will be processed in the new Transfer and Storage Services (TSS) facility at SRS and were therefore included in the technology risk assessment.

3. Criterion 2.1.1 of the MGDS Waste Acceptance Criteria (WAC) ${ }^{\circ}$ requires compliance with the Nuclear Waste Policy Act (NWPA) "legal" definition of SNF - namely, "fuel that has been withdrawn from a nuclear reactor following irradiation, the constituent elements of which have not been separated by reprocessing. ${ }^{\text {"10 }}$ For the purposes of this risk assessment, it is assumed that the

" Section 2.1 of the RAPP categorizes Moderate and High grade risks as unacceptable. 
Melt \& Dilute disposal form meets the intent of this definition (i.e. - treating the SNF to reduce enrichment and achieve the desired metallurgy is not considered to be reprocessing.)

\section{FINDINGS}

During the initial assessments, the team identified a total of 33 risks', 21 for Melt \& Dilute and 12 for Direct Co-Disposal. Nine of those risks' were later deemed by the team to be non-credible and were consequently eliminated from further consideration. Justifications for the elimination of these risks are found on the individual database records. An assessment summary for the remaining 24 active risks (14 Melt \& Dilute, 10 Direct Co-Disposal) may be found in Table 1 on Pages 13 \& 14.

Of the 24 active risks, there were 12 Low risks (9 Melt \& Dilute / 3 Direct Co-Disposal), 5 Moderate risks (3 Melt \& Dilute / 2 Direct Co-Disposal), and 7 High risks ( 2 Melt \& Dilute / 5 Direct Co-Disposal). The handling action selected by the team for all of the Low risks was Accept, as recommended by the RAPP, and no additional action was required. All of the Moderate risks were assigned a handling action of Mitigate, and based upon strategies identified in the database, all of those risks were reduced to Low with success probabilities that ranged from $95 \%$ to $100 \%$.

For the seven High risks, the team selected handling actions of Mitigate for five of the risks and Transfer for the other twok. Of the five High risks with mitigating handling actions, two were reduced to Low with success probabilities of $75 \%$ and $85 \%$, and the other three were reduced to Moderate with success probabilities of $100 \%$. The remaining 2 High risks (one for each technology) address the possibility of existing repository-level performance requirements being redefined and imposed at the SNF disposal-form-level by DOE-RW. While these risks were judged by the assessment team to be Very Unlikely, the potential impact of changes in repository requirements will be mitigated by SFSD's continuing dialog with DOE-RW and its Yucca Mountain repository managing and operating contractor.

\section{TECHNICAL RISK MITIGATION STRATEGIES}

As noted above, the team recommended mitigation strategies for all Moderate and High risks except for the two High risks that had selected handling actions of Transfer. The strategies recommended by the team may be found on Page 2 of each of the appropriate database records. Estimates for handling action' were not provided in the database as a part of this task but were instead identified as "to be determined" (TBD). The team agreed that completion of these estimates should be deferred as an action item for a future project team with the appropriate resources. In addition, because there were so few High and Moderate risks, the team did not attempt to rank them or select a Top-10 list as allowed by the RAPP"m.

\footnotetext{
1 Refer to the SNF Risk Assessment Database located in Appendix A.

I Risk ID numbers $06,07,08,12,15,19,26,27, \& 28$.

R Risk ID numbers 22 \& 23.

' Including Cost, Start Date, Completion Date, Resources Required, Closure Criteria, \& Fallback Strategy.

m Ref. 2, \$3.6.
} 


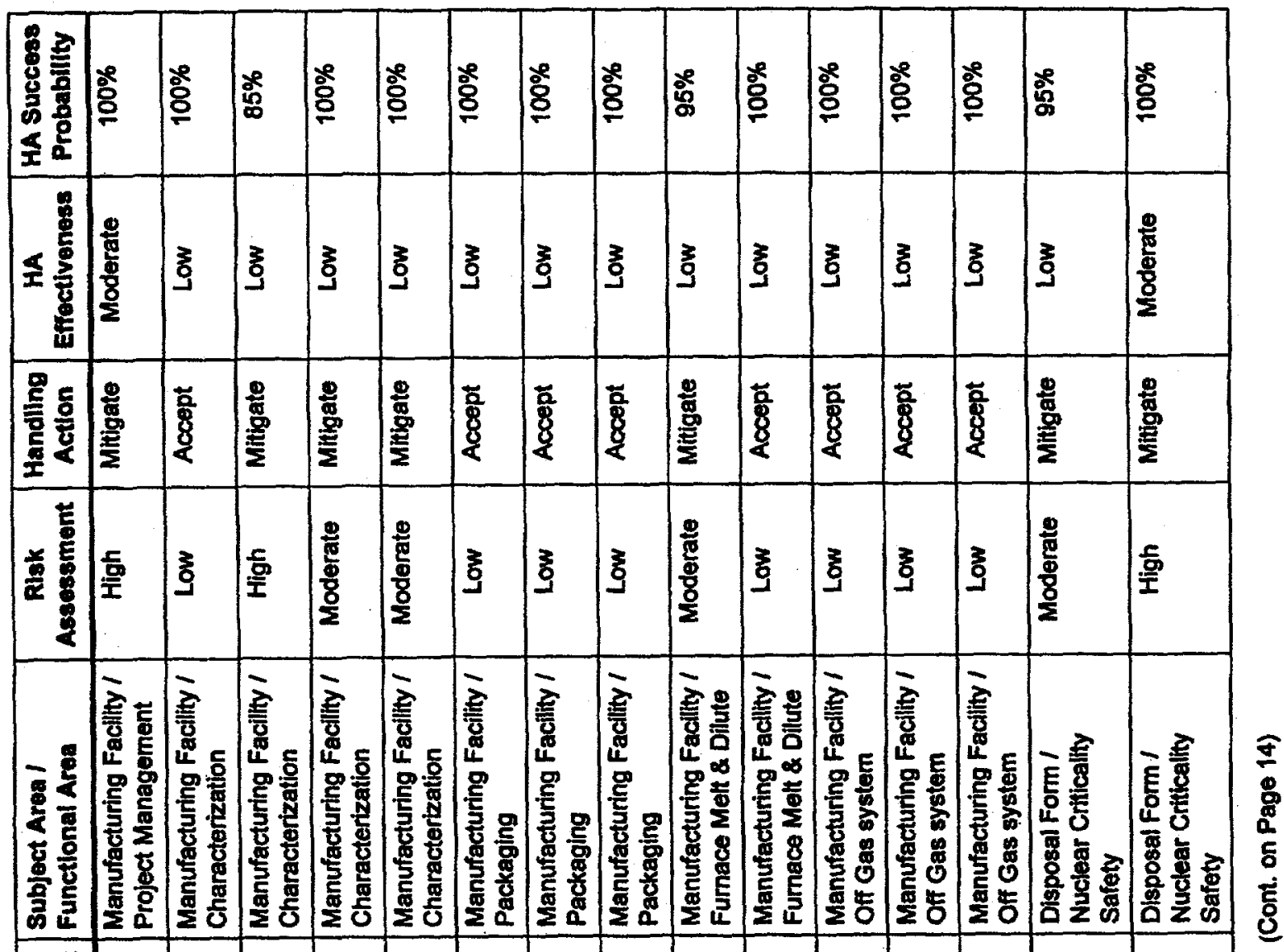

\begin{tabular}{|c|c|c|c|c|c|c|c|c|c|c|c|c|c|c|c|}
\hline 畐 & $\left.\right|_{x}$ & $\mid \underset{\substack{\tilde{X} \\
\boldsymbol{x}}}{\mathbf{N}}$ & 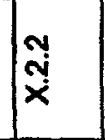 & $\underset{\substack{x \\
x}}{ }$ & ゙ָ & $\mid \begin{array}{l}\Delta \\
\dot{X} \\
\times\end{array}$ & 芯 & 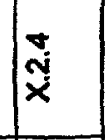 & $\underset{\substack{\mathfrak{N} \\
\underset{x}{x}}}{ }$ & 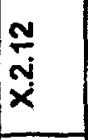 & $\underset{\substack{m \\
\dot{x}}}{\stackrel{m}{x}}$ & $\underset{\substack{m \\
\underset{x}{x}}}{\stackrel{m}{x}}$ & $\frac{\infty}{\mathcal{N}}$ & $\underset{\dot{x}}{\dot{x}}$ & $\underset{\nearrow}{\stackrel{\varphi}{亡}}$ \\
\hline 8 & 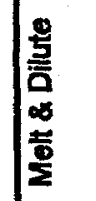 & 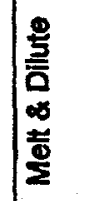 & 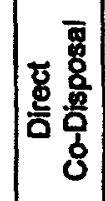 & 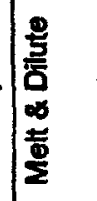 & 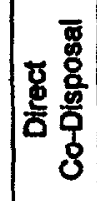 & 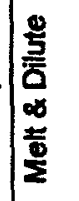 & 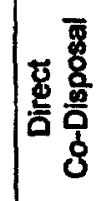 & 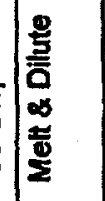 & 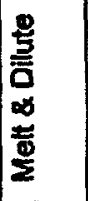 & $\begin{array}{l}\frac{g}{5} \\
\frac{5}{2} \\
\infty \\
\frac{5}{5} \\
\frac{1}{2}\end{array}$ & 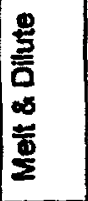 & 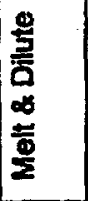 & $\begin{array}{l}\frac{0}{3} \\
\frac{\bar{z}}{0} \\
\infty \\
\frac{0}{2} \\
\frac{0}{2}\end{array}$ & 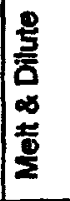 & 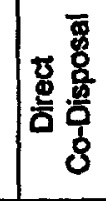 \\
\hline & 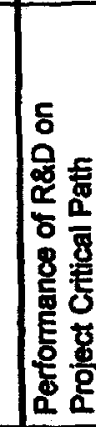 & 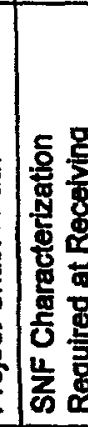 & 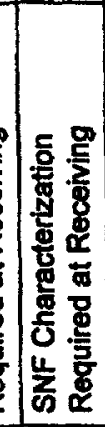 & 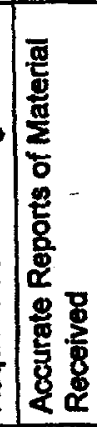 & 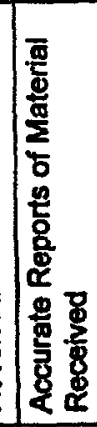 & 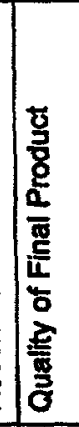 & 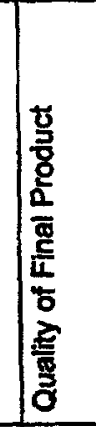 & 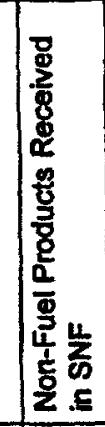 & 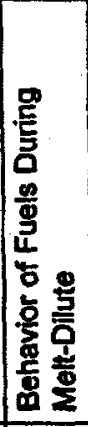 & 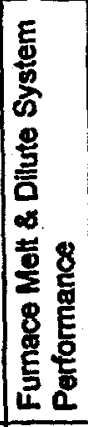 & 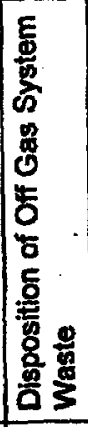 & 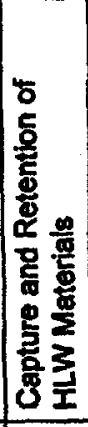 & 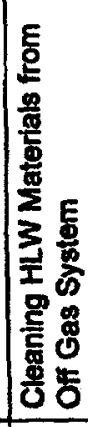 & 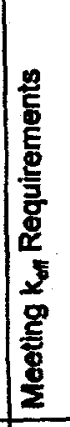 & 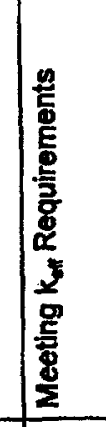 \\
\hline & & 10 & $1^{\circ}$ & 0 & 0 & 0 & - & $=$ & 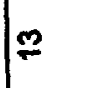 & \pm & 10 & $F$ & $\stackrel{\infty}{\stackrel{\infty}{\prime}}$ & lo & $\bar{N}$ \\
\hline
\end{tabular}




\begin{tabular}{|c|c|c|c|c|c|c|c|c|c|}
\hline 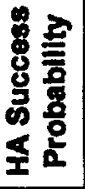 & 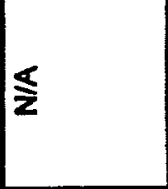 & $\$$ & 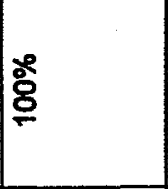 & 양 & శ̊ㅇㅇ & 各 & 总 & 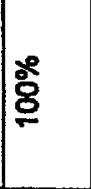 & 웅 \\
\hline 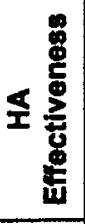 & $\widehat{\mathbf{z}}$ & $\widehat{z}$ & 容 & 3 & 章 & 3 & 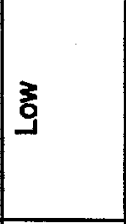 & 言 & 兽 \\
\hline 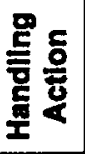 & 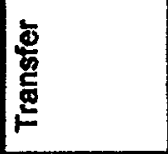 & 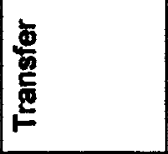 & 茗 & 妾 & 章 & $\frac{\pi}{8}$ & 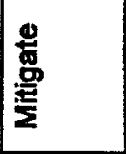 & 畺 & 惫 \\
\hline 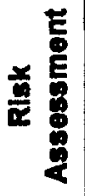 & 总 & 预 & 童 & 歽 & 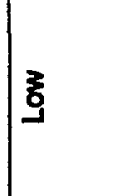 & $\bar{z}$ & 总 & $\begin{array}{l}\frac{9}{80} \\
\frac{50}{8} \\
\frac{8}{2} \\
\end{array}$ & 㽞 \\
\hline 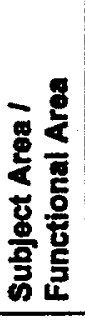 & 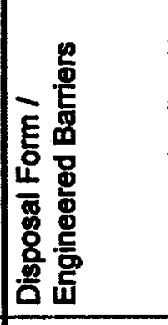 & 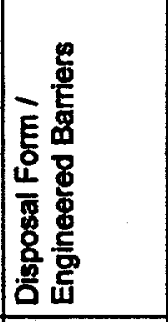 & 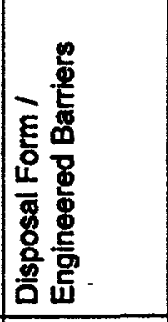 & 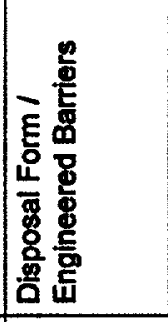 & 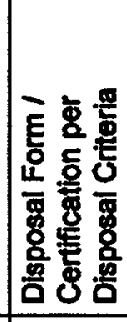 & 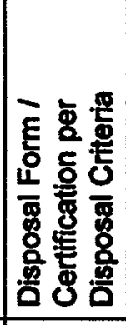 & 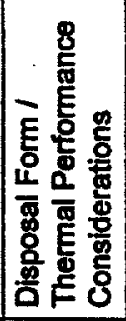 & 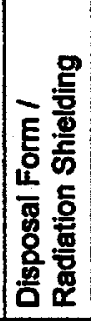 & 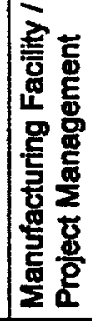 \\
\hline 兽总 & $\stackrel{\sim}{\check{r}}$ & $\stackrel{7}{\check{\gamma}}$ & $\underset{x}{\check{x}}$ & $\frac{7}{\check{\gamma}}$ & $\frac{F}{\dot{\Sigma}}$ & $\frac{F}{\dot{\Sigma}}$ & $\frac{\mathscr{y}}{\check{\gamma}}$ & $\underset{⿱ 亠 乂}{\check{\gamma}}$ & 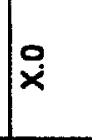 \\
\hline 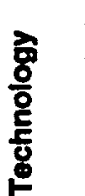 & 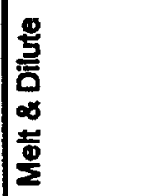 & 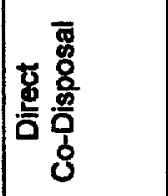 & 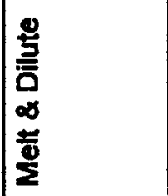 & 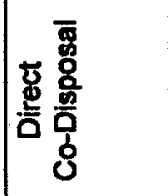 & 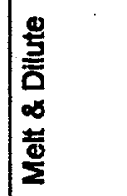 & 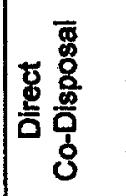 & 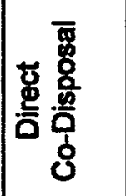 & 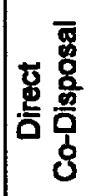 & 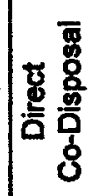 \\
\hline$\stackrel{\circ}{\underline{E}}$ & 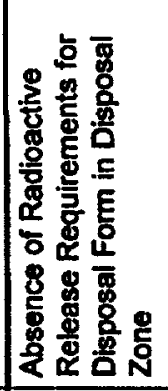 & 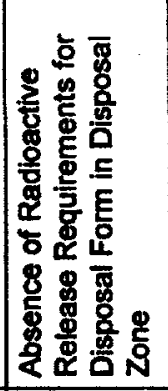 & 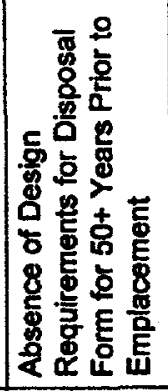 & 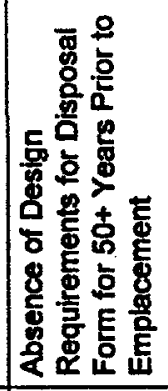 & 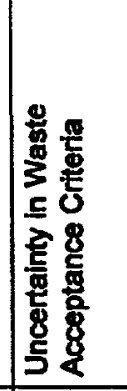 & 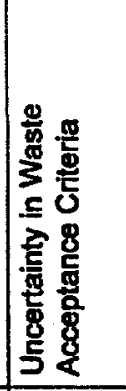 & 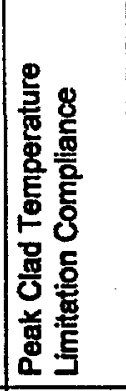 & 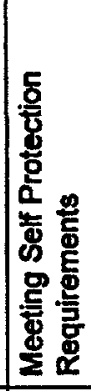 & 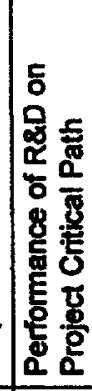 \\
\hline 总으 & $\mathbb{N}$ & జֶ & 泫 & జి & กิ & 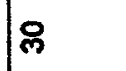 & $\bar{m}$ & న్ & m \\
\hline
\end{tabular}




\section{CONCLUSIONS}

The purpose of the SNF Altemative Technology Risk Assessment was to determine if elther, or both, of the alternative technologies recommended by the RRTT posed significant risks that would make them unsuitable for further development. Based upon the results of this assessment, it is the conclusion of the risk assessment team that the Melt \& Dilute and Direct Co-Disposal alternative technologies are both acceptable for further development provided mitigation strategies recommended by the team for Moderate and High risks are followed and tracked through completion by a project team. SFSD has committed to proceed with the risk management process throughout implementation of the Treatment and Storage Facility Project.

\section{REFERENCES}

1. Charles H. Kepner \& Benjamin B. Tregoe. The Now Rational Manager. McGraw-Hill, Princeton, NJ (1981).

2. John C. Devine, Jr., et. al. Technical Strategy for the Treatment, Packaging, and Disposal of Aluminum-Based Spent Nuclear Fuel - A Report of the Reseanch Reactor Spent Nuclear Fuel Task Team. Prepared for the Department of Energy, Office of Spent Fuel Management (1996).

3. L. W. Patrick. Risk Assessment Program Plan, Transfer and Storage Services for Aluminum-Based Spent Nuclear Fuel. SRS Document G-ESR-G-00027, Rev. 0, Savannah River Site, Aiken, SC 29808 (1997).

4. Grant A. Cook, et. al. Savannah River Site Spent Nuclear Fuel Transfer and Storage Services Preconceptual Design. SRS Document G-CDP-G-00002, Rev. Draft B, Savannah River Site, Aiken, SC 29808 (1997).

5. Conduct of Engineering and Technical Support, Technical Risk Analysis (Procedure 2.16, Rev. 0, 7/1/95). WSRC Manual E7, Savannah River Site, Aiken, SC 29808.

6. Andrew P. Sage. Systems Engineering. ISBN 0-471-53639-3, John Wiley \& Sons, Inc., New York, NY (1992).

7. Project Management and Control Methods, Project Risk Analysis (Guide 1.3, Rev. 0, 2/1/97). WSRC Manual WSRC-IM-95-00020, Savannah River Site, Aiken, SC 29808.

8. Conduct of Project Management and Control, Project Risk Analysis (Procedure 2.62, Rev. 1 , 2/1/97). WSRC Manual E11, Savannah River Site, Aiken, SC 29808.

9. Mark S. Abashian. Mined Geologic Disposal System Waste Acceptance Criteria. USDOE Report B00000000-01717-4600-00095, Rev. 00, TRW Environmental Safety Systems Inc., Las Vegas, NV 89134 (1997).

10. United States Code, Title 42, Chapter 108. Nuclear Waste Policy. (\$10101. Definitions).

11. The Code of Federal Regulations, Title 10, Part 60. Disposal of High-Level Radioactive Wastes in Geologic Repositories.

12. Quality Assurance Requirements and Description for the Civilian Radioactive Waste Management Program. U.S. DOE Document DOE/RW-0333P

13. Joseph F. Krupa. Savannah River Site Aluminum-Clad Spent Nuclear Fuel Altemative Cost Study Rev 1(U). USDOE Report WSRC-TR-97-299, Savannah River Site, Alken, SC 29808 (1997). 
14. Robert L. Sindelar, et. al. Altemative Aluminum Spent Nuclear Fuel Treatment Technology Development Status Report. USDOE Report WSRC-TR-97-00345, Savannah River Site, Aiken, SC 29808 (1997).

15. The Code of Federal Regulations, Title 49, Part 173. Shippers - General Requirements for Shipments and Packagings.

16. ANSI N14.5-1997. Radioactive Materials - Leakage Tests on Packages for Shipment. American National Standards Institute, New York, NY 10036 (1997).

17. The Code of Federal Regulations, Titte 10, Part 73. Physical Protection of Plants and Materials.

18. Waste Acceptance System Requirements Document (WASRD). USDOE Document DOE/RW0351P/E00000000-00811-1708-00001, Rev. 1, U.S. DOE Office of Civilian Radioactive Waste Management, Washington, DC 20585 (1994).

\section{APPENDIXES}

Appendix A: SNF Risk Assessment Database 


\section{Appendix A}

SNF Risk Assessment Database

\section{TABLE OF CONTENTS}

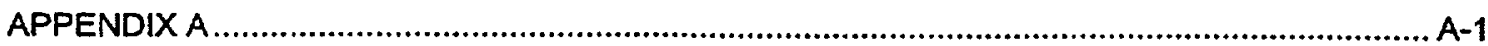

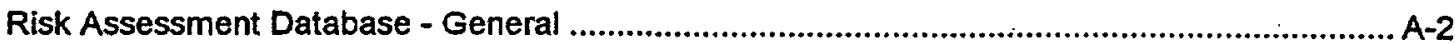

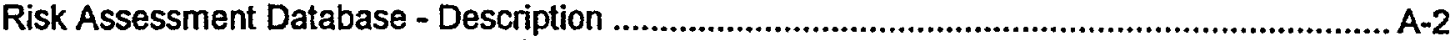

Risk Assessment Database - Active Records.................................................................. A-5

Risk Assessment Database - Deleted Records .......................................................... A-54 


\section{Risk Assessment Database - General}

The risk assessment database that comprises this appendix is a collection of data on all the identified project risks and reflects the current status of each risk. A two-page database record exists for each of the identified risks and contains all of the pertinent information collected during the assessment process for that specific risk. The database was created in compliance with the requirements of Section 4 of the RAPP. Custody of the database will be transferred to SFSD Engineering following the issuance of this report.

\section{Risk Assessment Database - Description}

The following paragraphs identify the database field names and provide a brief description of the field contents in the context of the risk assessment process. The location of the field on each of the records (Page 1 and/or Page 2) is also identified.

\section{RISK ID (Pages 1\& 2)}

A unique serial number which is assigned to the record when each new risk is entered into the database. The new ID number is the last previous risk ID number incremented by 1 .

ORIGIN DATE (Pages 1 \& 2)

The calendar date for initial entry of risk information into the database.

\section{REV NO (Pages 1 \& 2)}

The current revision number for the risk. Starts with 0 and increments by 1 each time the risk undergoes a change in nature or handling strategy.

\section{STATUS DATE (Pages $1 \& 2$ )}

The calendar date of the last formal review of risk status. Also, the calendar date of the last updating of the risk record data.

\section{STATUS (Pages 1 \& 2)}

Current status of record. Status will be either Active, Closed, or Deleted.

\section{WBS ELEMENT (Pages 1 \& 2)}

The particular WBS element(s) which the risk will most likely impact (Ref. Figures 4 \& 5 in the body of the report).

\section{SUBJECT AREA (Pages 1 \& 2)}

The subject area under which the WBS element impacted by the risk may be found (Ref. Figures 4 \& 5 in the body of the report).

\section{FUNCTIONAL AREA (Pages $1 \& 2$ )}

The functional area description for the WBS element impacted by the risk (Ref. Figures $4 \& 5$ in the body of the report).

\section{TECHNOLOGY (Pages $1 \&$ 2)}

The specific technology impacted by the risk. For this assessment, technology will be either Direct Co-Disposal or Mett \& Dilute. 
TITLE (Pages $1 \& 2$ )

A brief descriptive title for the risk.

RISK CATEGORY (Pages 1 \& 2)

The technical risk category from Attachment 8.2 of WSRC Manual E7 Procedure 2.16. T-1 indicates category 1 under Technology, $1-1$ indicates category 1 under Interfaces; etc..

\section{RISK FACET (Pages 1 \& 2)}

The risk type or facet. Facets may be Technical Performance, Logistic Support, Disposition, Safety, Environmental, Programmatic, Cost, or Schedule.

\section{RISK ASSESSMENT (Pages 1 \& 2)}

The initial assessment results for risk grading, either Low, Moderate, or High.

\section{RANK (Pages 1 \& 2)}

The current rank order number for the Active risks. The Risk Assessment Team determines this number. A rank of 1 indicates the most significant Active risk.

\section{DESCRIPTION (Page 1)}

A brief description of the risk and the basis for the risk. The basis includes a brief discussion of impacts if the risk were to occur, e.g., damaged SNF, unacceptable or rejected SNF disposal form, environmental releases, a contamination event, etc.

\section{PROBABILITY OF RISK (Page 1)}

Initial assessment of risk probability. The possible values of the field are Very Unlikely, Unlikely, and Likely.

\section{RISK PROBABILITY SOURCE (Probability of Risk) (Page 1)}

Indicates the source of the estimate. The possible values of the field are Team Engineering Judgement or Technical Analysis.

\section{BASIS (Probability of Risk) (Page 1)}

A brief statement that provides the basis for the assessed risk probability.

\section{CONSEQUENCE OF RISK (Page 1)}

Initial assessment of risk consequence(s). The possible values of the field are Negligible, Marginal, and Critical.

\section{RISK CONSEQUENCE SOURCE (Consequence of Risk) (Page 1)}

Indicates the source of the estimate. The possible values of the field are Team Engineering Judgement or Technical Analysis.

\section{BASIS (Consequence of Risk) (Page 1)}

A brief statement that provides the basis for the assessed risk consequence(s). 


\section{HANDLING ACTION (Page 2)}

Risk handling action recommended by Risk Team. The possible values of the field are Mitigate, Avoid, Transfer, or Accept.

BASIS (Handling Action) (Page 2)

A brief, high-level description of the risk handling action necessary to implement the strategy, with references to other documents for detail. Mitigation lists \& summarizes recommended future development, study, modeling or other handling activities.

\section{EFFECTIVENESS (Estimates for Handling Action) (Page 2)}

The anticipated grade of the risk (High, Moderate, or Low) after a successful handling action is complete.

\section{SUCCESS PROBABILITY (Estimates for Handling Action) (Page 2)}

An estimate of the probability that handling action will be successful. Expressed in terms of percent. CosT (Estimates for Handling Action) (Page 2)

An estimate of the cost for performing the handling action.

START DATE (Estimates for Handling Action) (Page 2)

An estimate of the calendar date at which the handling action should begin

\section{COMPLETION DATE (Estimates for Handling Action) (Page 2)}

An estimate of the calendar date at which the handling action could be complete.

RESOURCE REQUIRED (Estimates for Handling Action) (Page 2)

A brief description of the people, tools, facilities and other resources needed to execute the handling action.

\section{CLOSURE CRITERIA (Page 2)}

The closure criteria that confirm a successful completion of handling action. Criteria must be met to initiate risk closure.

\section{FALlBACK STRATEGY (Page 2)}

A brief. summary of an alternative handling action should the recommended handling action fail to manage the risk. 


\section{Risk Assessment Database - Active Records}

\begin{tabular}{|c|c|c|c|c|c|}
\hline $\begin{array}{c}\text { Risk } \\
\text { to }\end{array}$ & Title & Technology & $\begin{array}{c}\text { WBS } \\
\text { Element }\end{array}$ & $\begin{array}{l}\text { Subject Area / } \\
\text { Functional Area }\end{array}$ & Page \\
\hline 01 & Performance of R\&D on Project Critical Path & Melt \& Dllute & $\mathbf{X . 0}$ & $\begin{array}{l}\text { Manufacturing Facility } / \\
\text { Project Management }\end{array}$ & $\begin{array}{l}A-6 \\
A-7\end{array}$ \\
\hline 02 & SNF Characterization Required at Receiving & Melt \& Dilute & $\times .2 .2$ & $\begin{array}{l}\text { Manufacturing Facillty / } \\
\text { Characterization }\end{array}$ & $\begin{array}{l}A-8 \\
A-9\end{array}$ \\
\hline 03 & SNF Characterization Required at Receiving & Direct Co-Disposal & $\times .2 .2$ & $\begin{array}{l}\text { Manufacturing Facility / } \\
\text { Characterization }\end{array}$ & $\begin{array}{l}A-10 \\
A-11\end{array}$ \\
\hline 04 & Accurate Reports of Material Received & Melt \& Dilute & $\times .2 .2$ & $\begin{array}{l}\text { Manufacturing Facility / } \\
\text { Characterization }\end{array}$ & $\begin{array}{l}A-12 \\
A-13\end{array}$ \\
\hline 05 & Accurate Reports of Material Received & Direct Co-Dlsposal & $\mathrm{X} .2 .2$ & $\begin{array}{l}\text { Manufacturing Facility } / \\
\text { Characterization }\end{array}$ & $\begin{array}{l}A-14 \\
A-15\end{array}$ \\
\hline$\infty$ & Quality of Final Product & Melt \& Dilute & $X .2 .4$ & $\begin{array}{l}\text { Manufacturing facility } / \\
\text { Packaging }\end{array}$ & $\begin{array}{l}A-16 \\
A-17\end{array}$ \\
\hline 10 & Quality of Final Product & Direct Co-Disposal & $\times 2.4$ & $\begin{array}{l}\text { Manufacturing Facility' } \\
\text { Packaging }\end{array}$ & $\begin{array}{l}\text { A-18 } \\
\text { A-19 }\end{array}$ \\
\hline 11 & Non-Fuel Products Received in SNF & Melt \& Dilute & $\times .2 .4$ & $\begin{array}{l}\text { Manufacturing Facllity / } \\
\text { Packaging }\end{array}$ & $\begin{array}{l}A-20 \\
A-21\end{array}$ \\
\hline 13 & Behavior of Fuels During Melt-Dilute & Melt \& Dilute & $X .2 .12$ & $\begin{array}{l}\text { Manufacluring Facility } / \\
\text { Fumace Melt \& Dilute }\end{array}$ & $\begin{array}{l}A-22 \\
A-23\end{array}$ \\
\hline 14 & Furnace Melt \& Dilute System Performance & Melt \& Dilute & $\times .2 .12$ & $\begin{array}{l}\text { Manufacturing Facility I } \\
\text { Fumace Melt \& Dilute }\end{array}$ & $\begin{array}{l}A-24 \\
A-25\end{array}$ \\
\hline 16 & Disposition of Off Gas System Waste & Meft \& Dilute & $\times 2.13$ & $\begin{array}{l}\text { Manufacturing Facility } \\
\text { Off Gas system }\end{array}$ & $\begin{array}{l}A-26 \\
A-27\end{array}$ \\
\hline 17 & Capture and Retention of HLW Materials. & Melt \& Dilute & $\times .2 .13$ & $\begin{array}{l}\text { Manufacturing Facility } \\
\text { Off Gas system }\end{array}$ & $\begin{array}{l}A-28 \\
A-29\end{array}$ \\
\hline 18 & Cleaning HLW Materials from Oft Gas System & Melt \& Dilute & $X .2 .13$ & $\begin{array}{l}\text { Manufacturing Facility / } \\
\text { Off Gas system }\end{array}$ & $\begin{array}{l}\text { A-30 } \\
\text { A-31 }\end{array}$ \\
\hline 20 & Meeting $k_{\text {ord }}$ Requirements & Melt \& Dilute & Y.1.6 & $\begin{array}{l}\text { Disposal Form / Nuclear } \\
\text { Criticality Safety }\end{array}$ & A-32 \\
\hline 21 & Meeting kon Requirements & Direct Co-Disposal & Y.1.6 & $\begin{array}{l}\text { Disposal Form / Nuclear } \\
\text { Critically Safety }\end{array}$ & $\begin{array}{l}\text { A-34 } \\
\text { A-35 }\end{array}$ \\
\hline 22 & $\begin{array}{l}\text { Absence of Radioactive Release Requirements } \\
\text { for Disposal Form in Disposal Zone }\end{array}$ & Melt \& Dilute & Y.1.7 & $\begin{array}{l}\text { Disposal Form / Engineered } \\
\text { Barriers }\end{array}$ & $\begin{array}{l}A-36 \\
A-37\end{array}$ \\
\hline 23 & $\begin{array}{l}\text { Absence of Radioactive Release Requirements } \\
\text { for Disposal Form in Disposal Zone }\end{array}$ & Direct Co-Disposal & Y.1.7 & $\begin{array}{l}\text { Disposal Form / Englneered } \\
\text { Barriers }\end{array}$ & $\begin{array}{l}A-38 \\
A-39\end{array}$ \\
\hline 24 & $\begin{array}{l}\text { Absence of Design Requirements for Disposal } \\
\text { Form for } 59+\text { Years Prior to Emplacement }\end{array}$ & Melt \& Dilute & Y.1.7 & $\begin{array}{l}\text { Disposal Form / Engineered } \\
\text { Barriers }\end{array}$ & $\begin{array}{l}A-40 \\
A-41\end{array}$ \\
\hline 25 & $\begin{array}{l}\text { Absence of Design Requirements for Disposal } \\
\text { Form for } 59+\text { Years Prior to Emplacement }\end{array}$ & Direct Co-Disposal & Y.1.7 & $\begin{array}{l}\text { Disposal Form / Engineered } \\
\text { Barriers }\end{array}$ & $\begin{array}{l}A-42 \\
A-43\end{array}$ \\
\hline 29 & Uncertainty in Waste Acceptance Criteria & Melt \& Dilute & Y.1.11 & $\begin{array}{l}\text { Disposal Form / Certification } \\
\text { per Disposal Criteria }\end{array}$ & $\begin{array}{l}A-44 \\
A-45\end{array}$ \\
\hline 30 & Uncertainty in Waste Acceptance Criteria & Direct Co-Disposal & Y.1.11 & $\begin{array}{l}\text { Disposal Form / Certification } \\
\text { per Disposal Crtteria }\end{array}$ & $\begin{array}{l}A-46 \\
A-47\end{array}$ \\
\hline 31 & Peak Ctad Temperature Limitation Compliance & Direct Co-Disposal & Y.1.12 & $\begin{array}{l}\text { Disposal Form / Thermal } \\
\text { Performance Considerations }\end{array}$ & $\begin{array}{l}A-48 \\
A-49\end{array}$ \\
\hline 32 & Meeting Self Protection Requirements & Direct Co-Disposal & Y.1.8 & $\begin{array}{l}\text { Disposal Form / Radiation } \\
\text { Shielding }\end{array}$ & $\begin{array}{l}A-50 \\
A-51\end{array}$ \\
\hline 33 & Performance of R\&D on Project Critical Path & Direct Co-Disposal & $\mathbf{x . 0}$ & $\begin{array}{l}\text { Manufacturing Facllty/ } \\
\text { Project Management }\end{array}$ & $\begin{array}{l}A-52 \\
A-53\end{array}$ \\
\hline
\end{tabular}




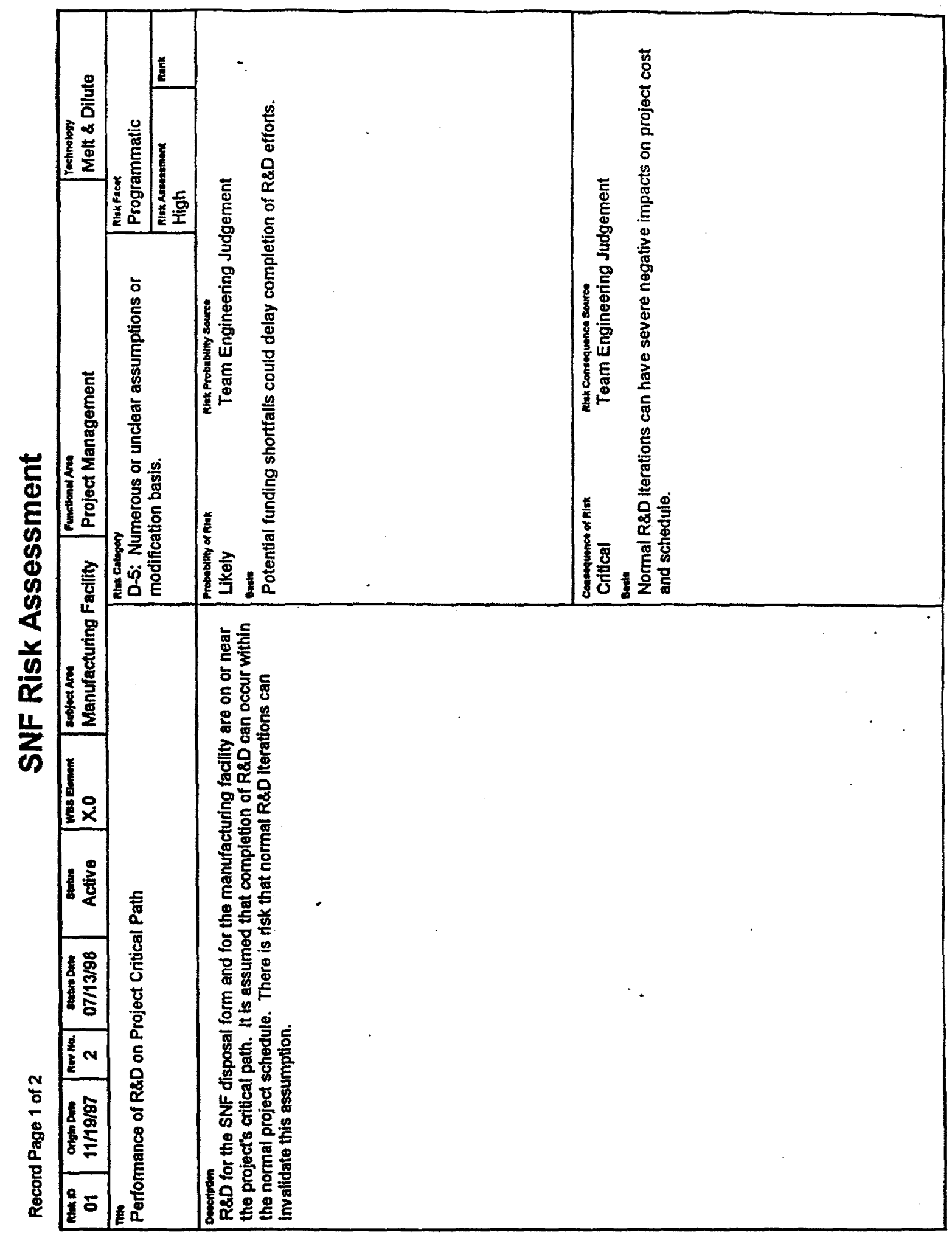




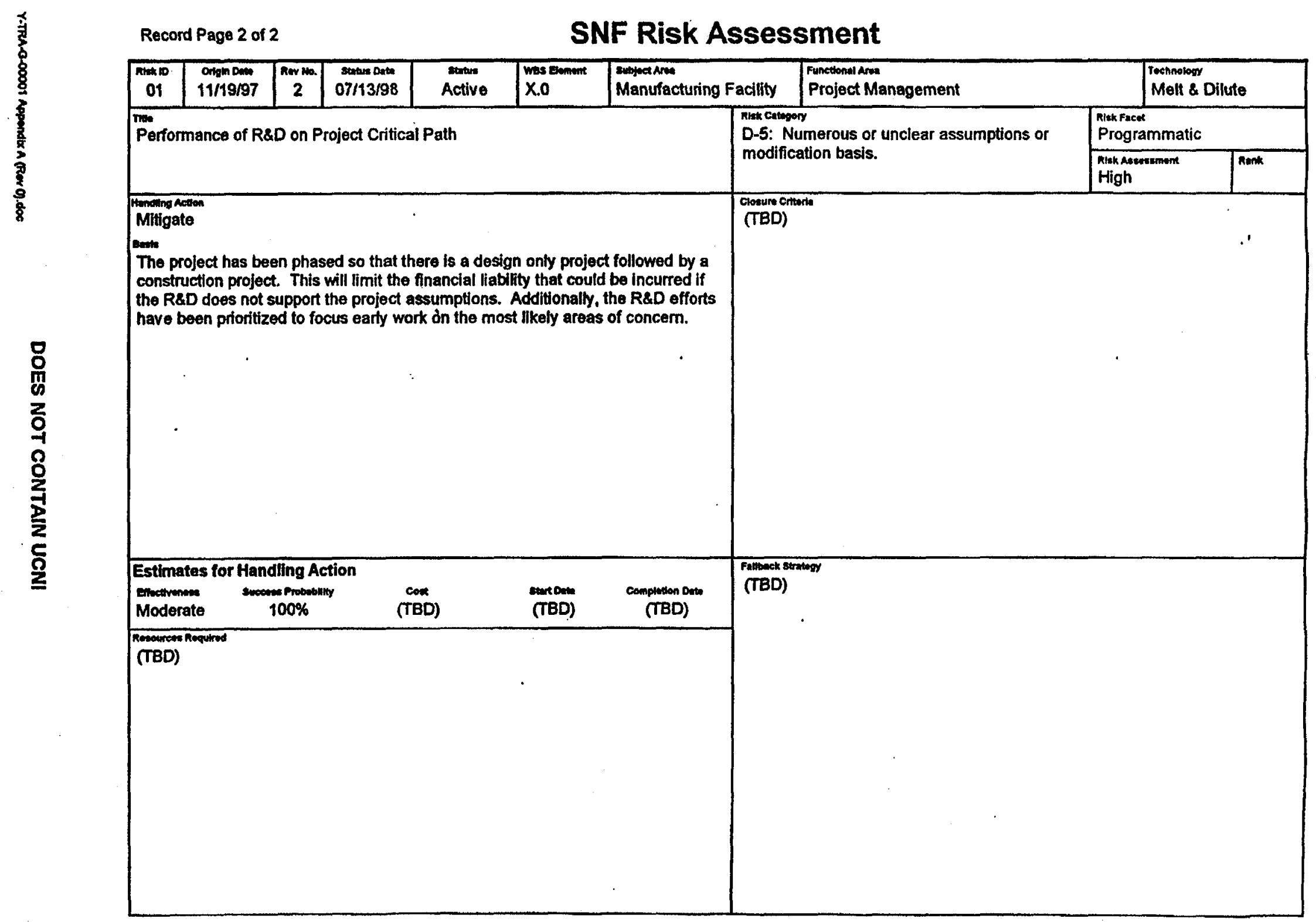




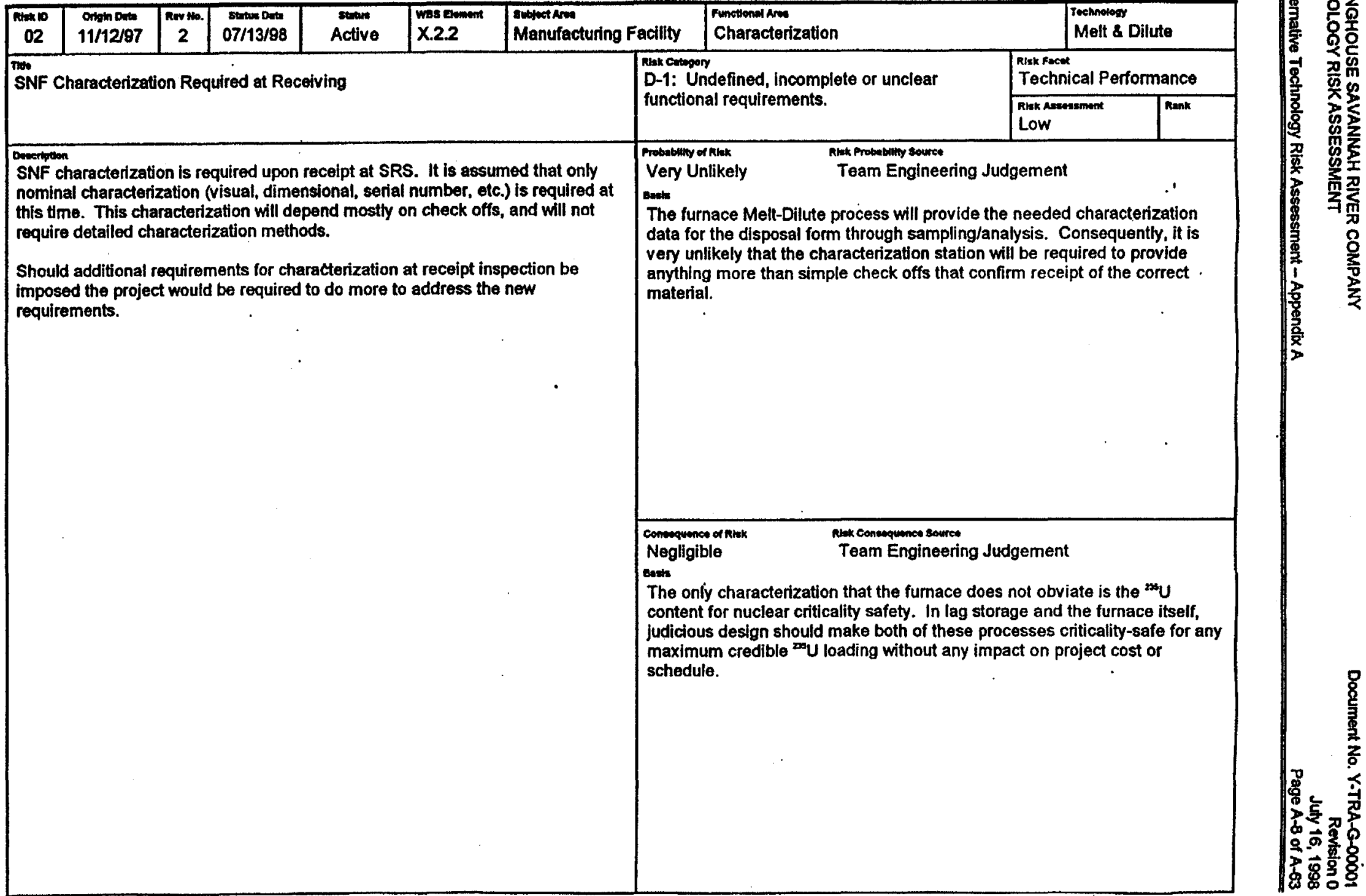




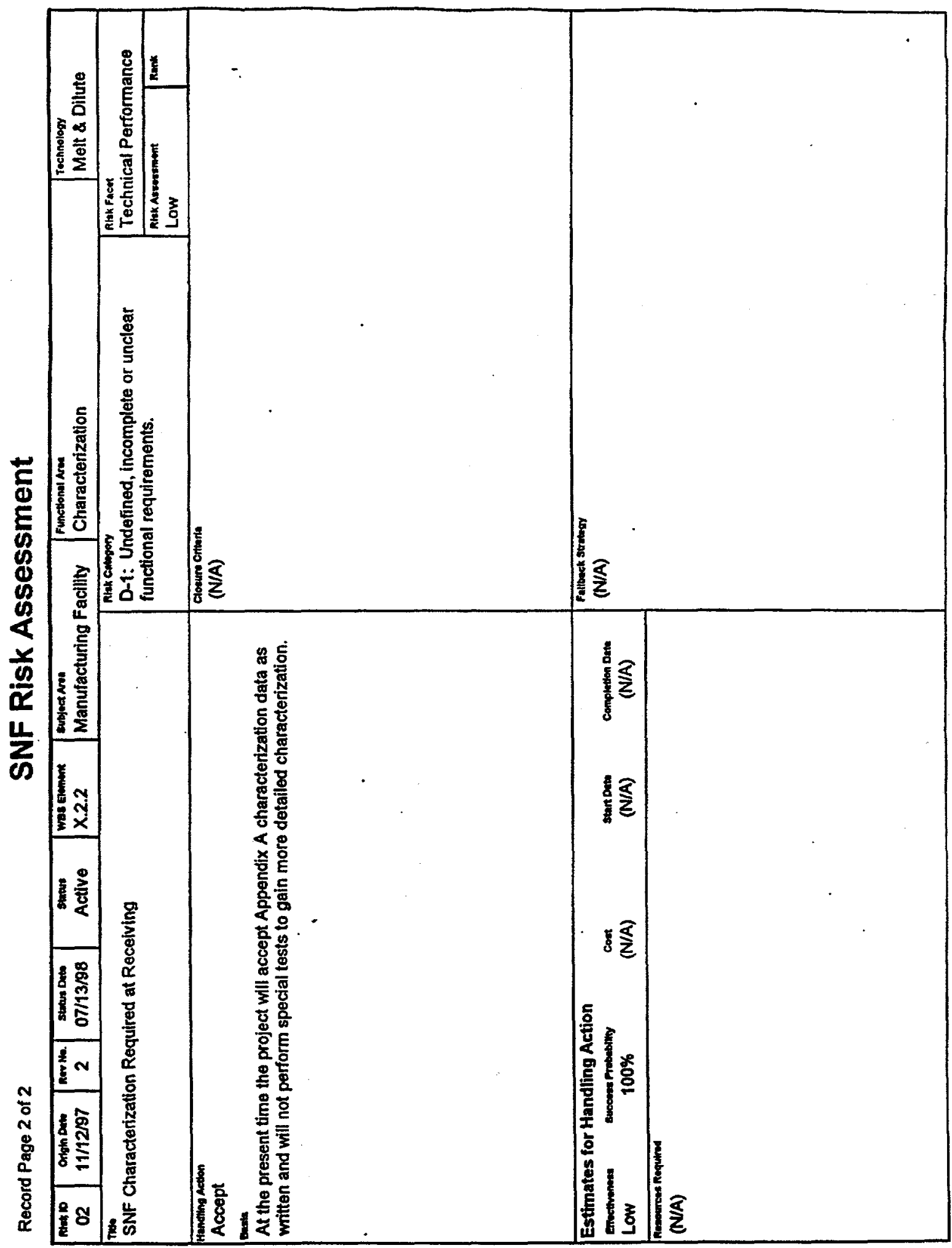




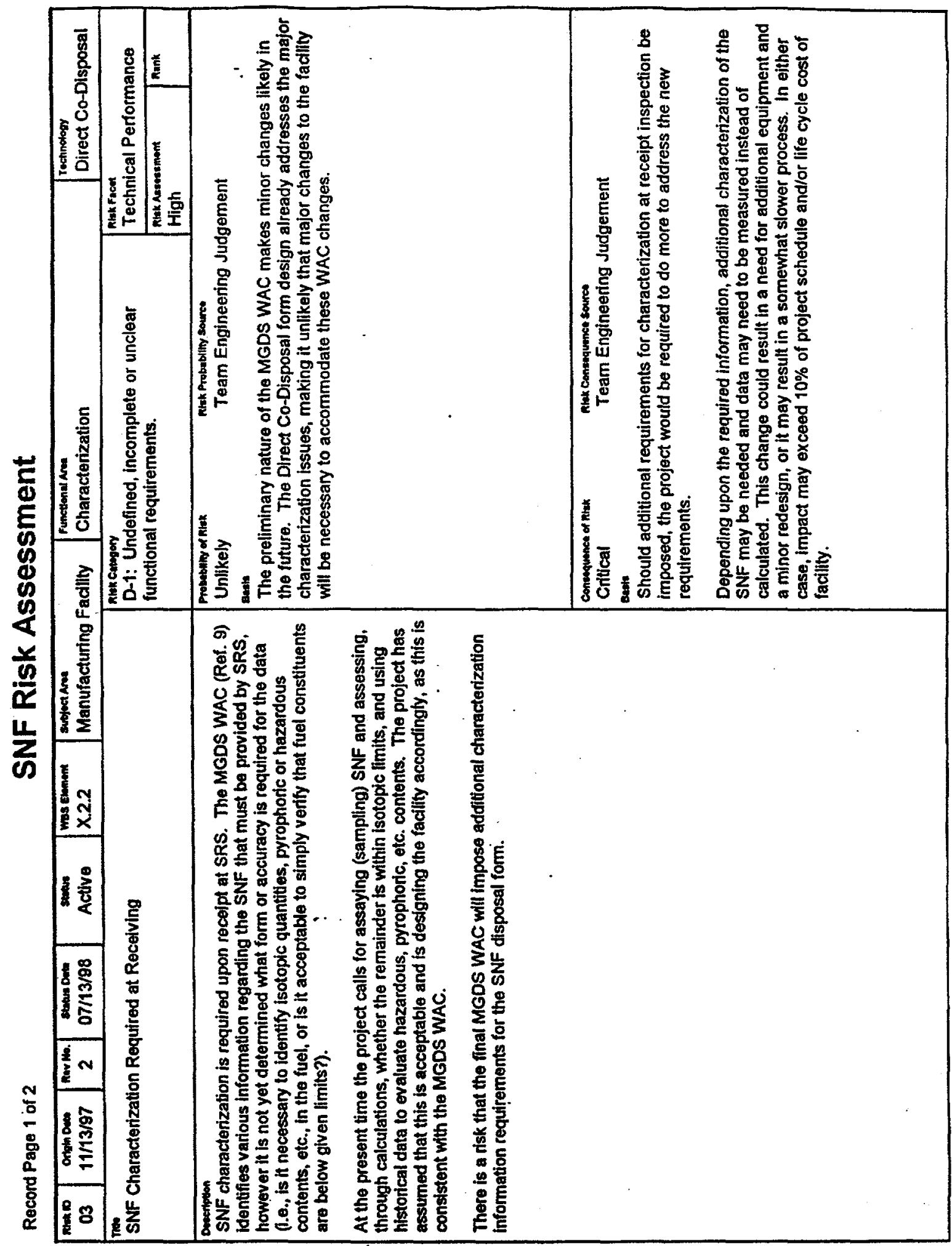




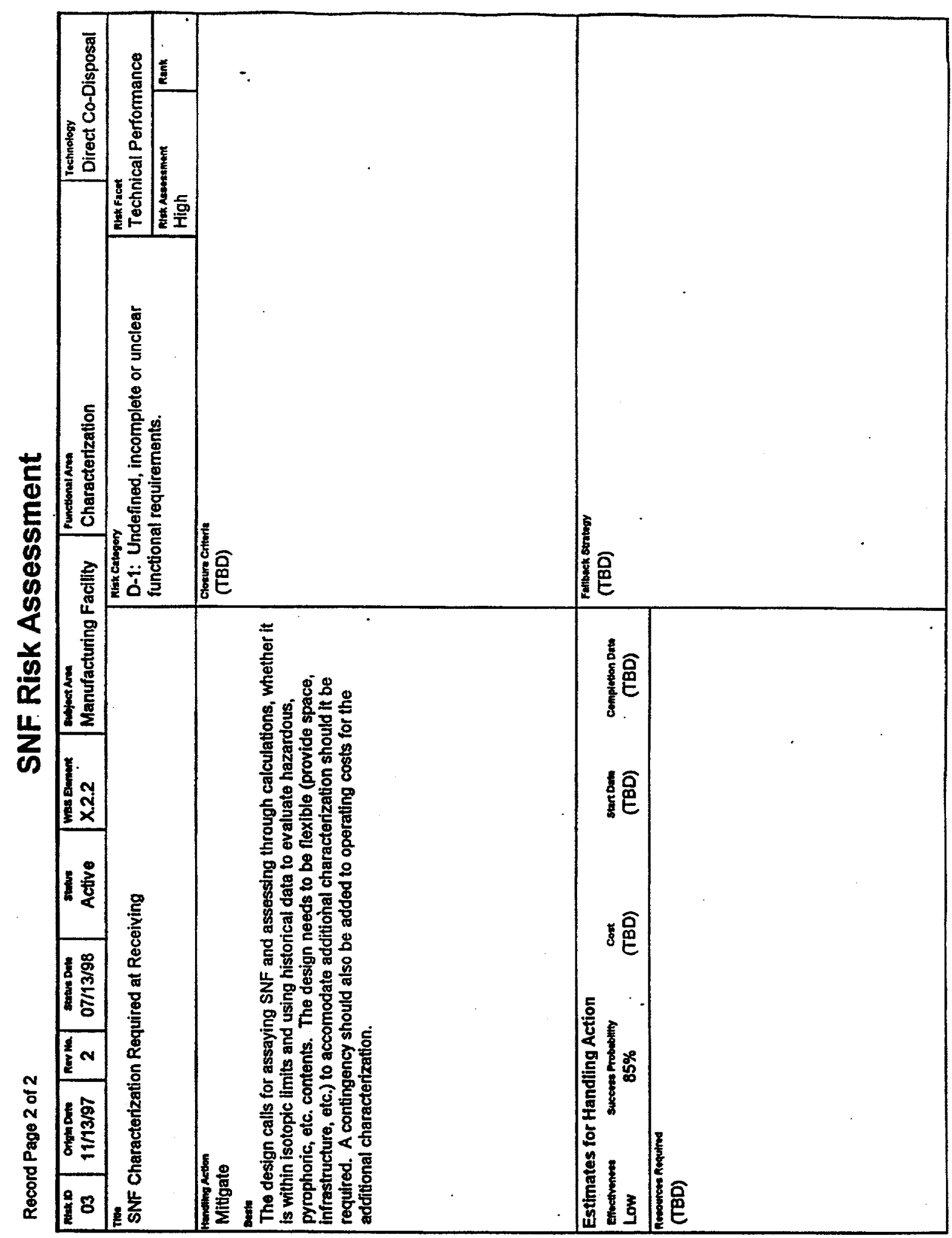




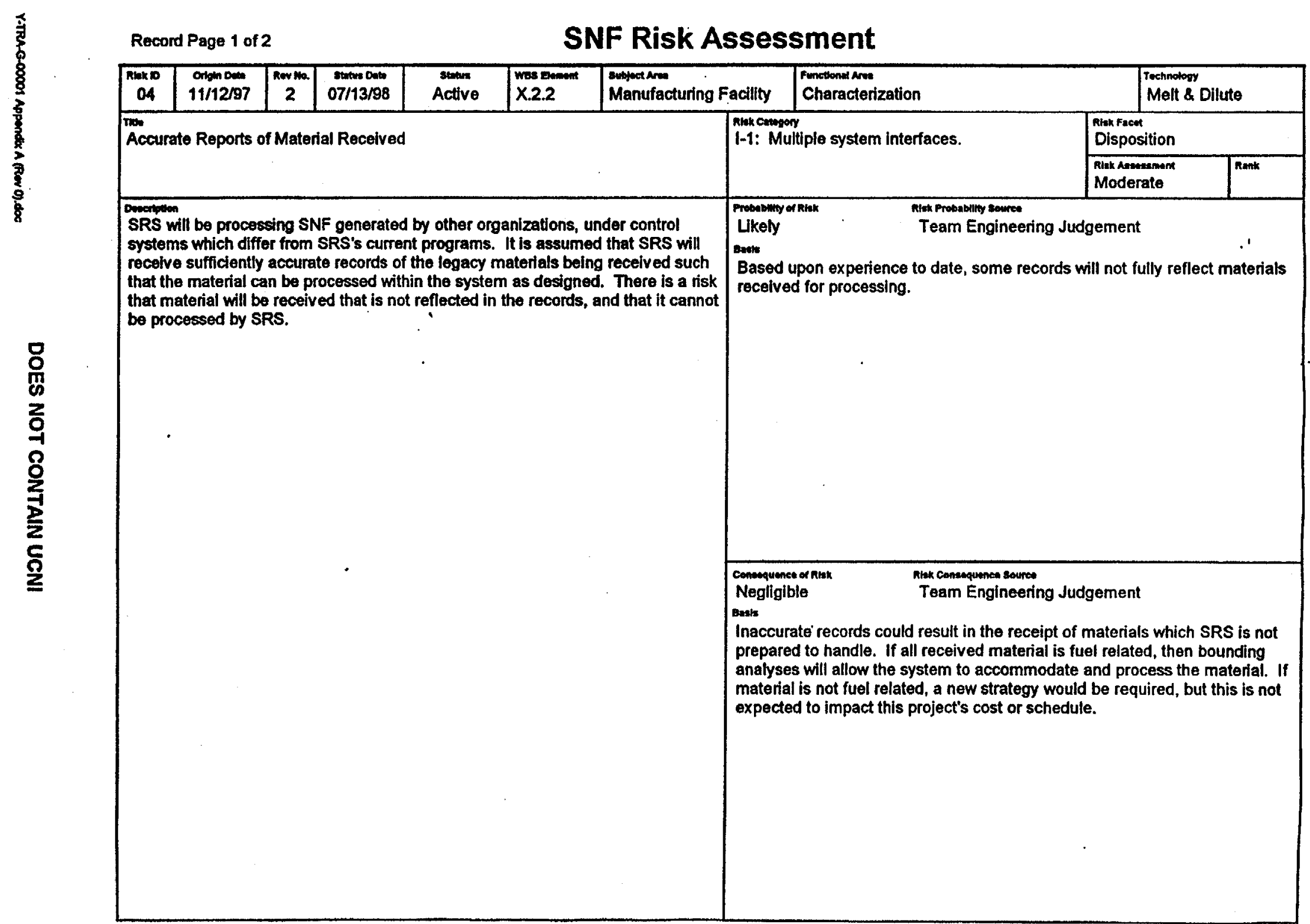




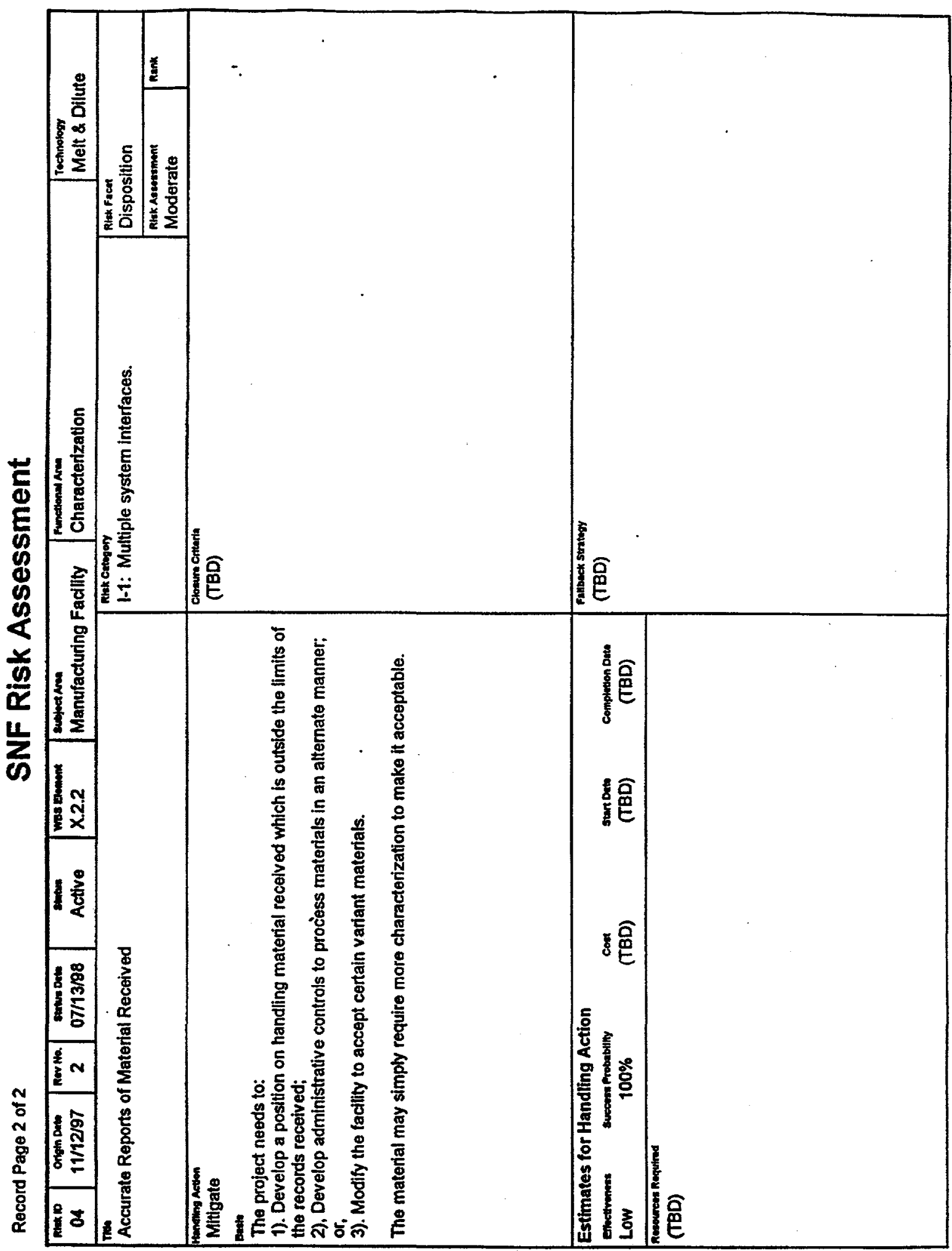




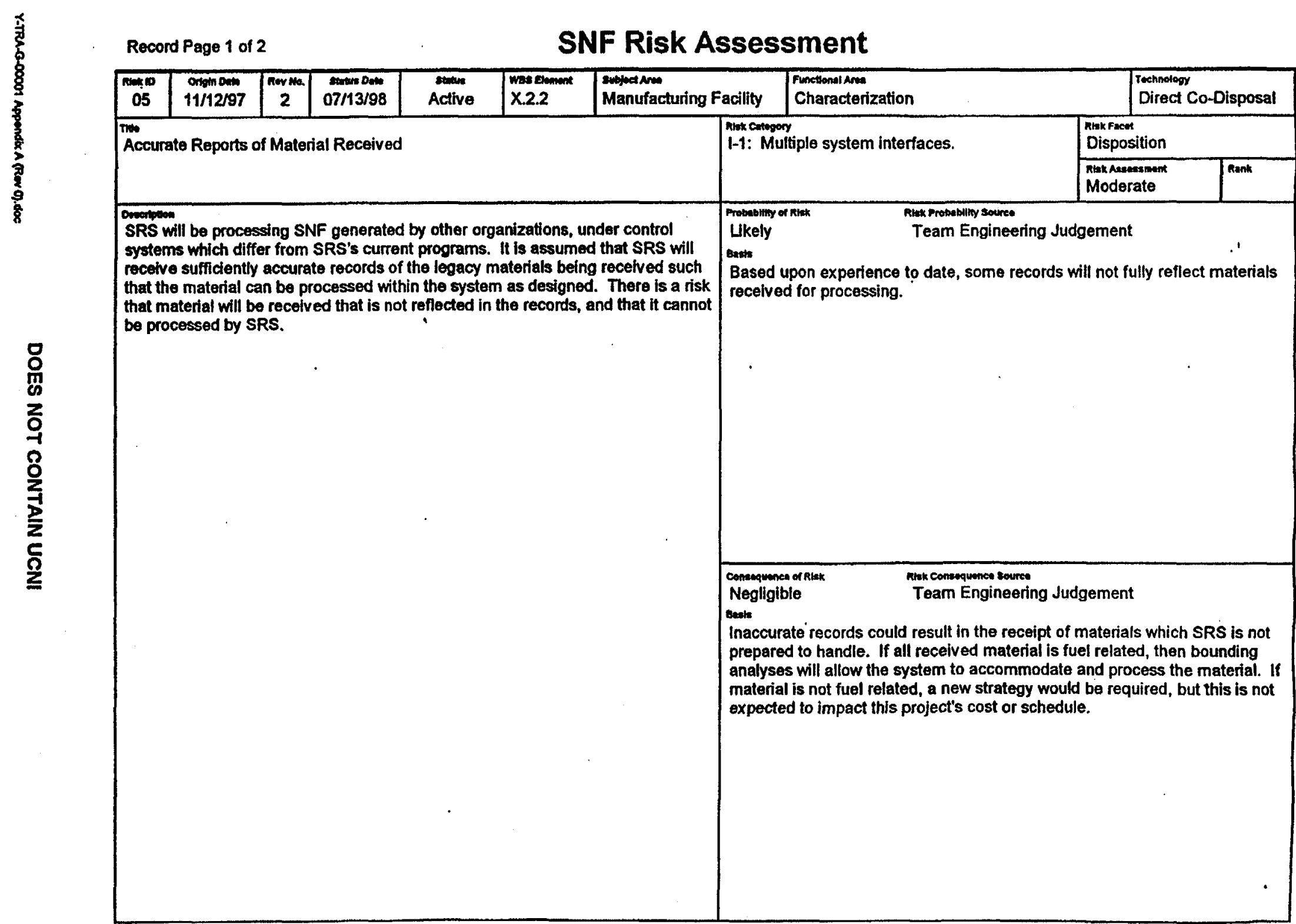




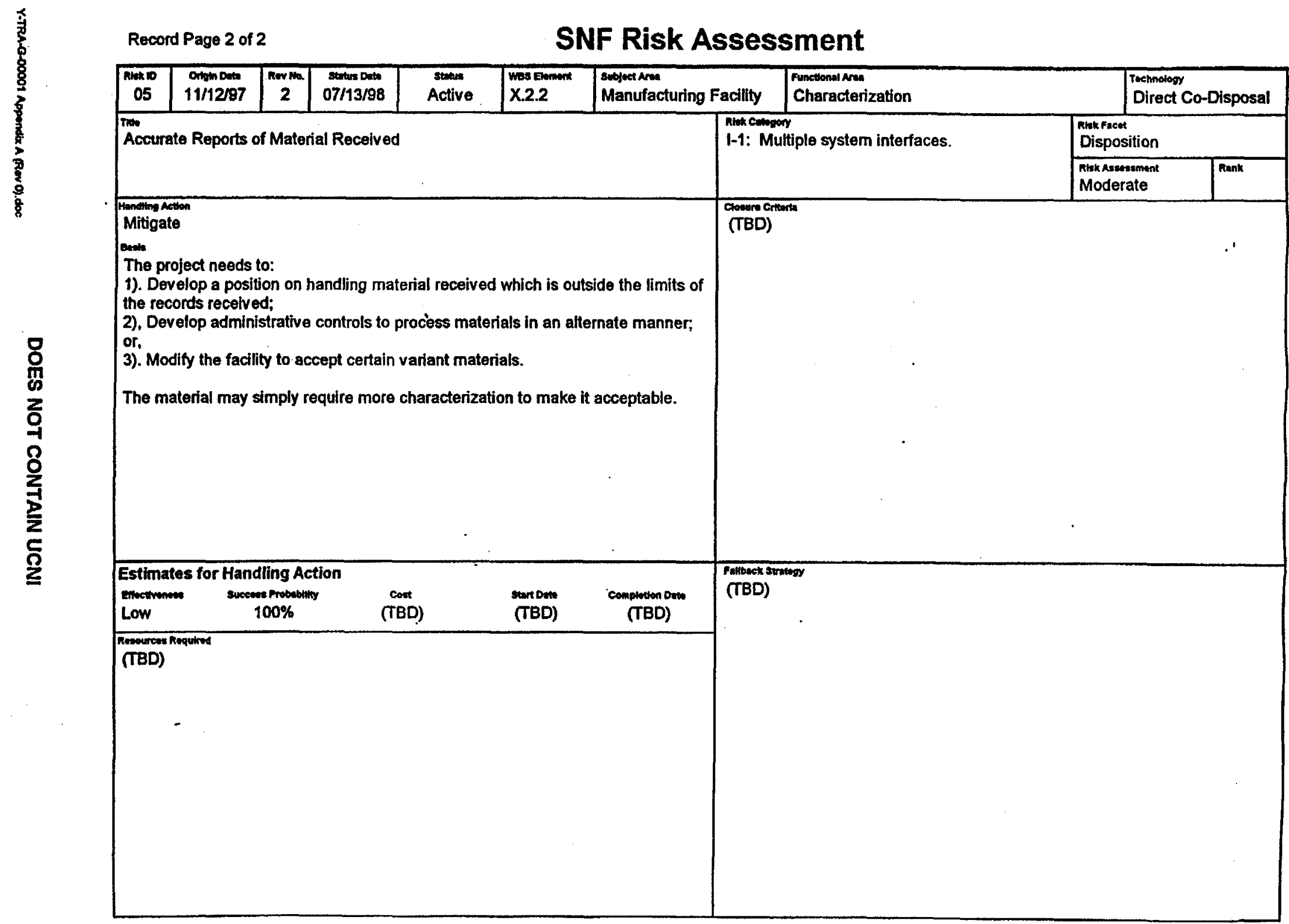


SNF Risk Assessment

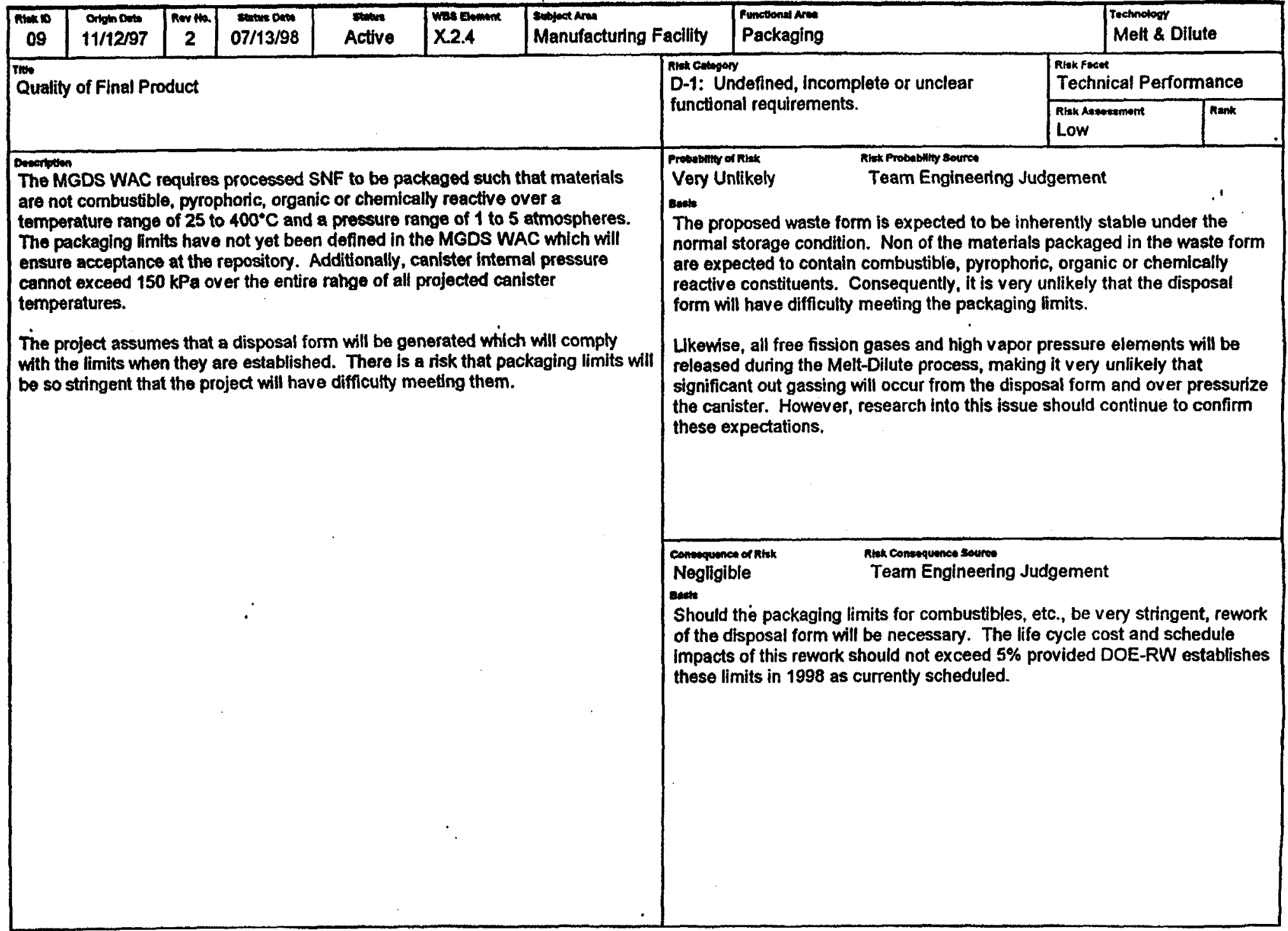




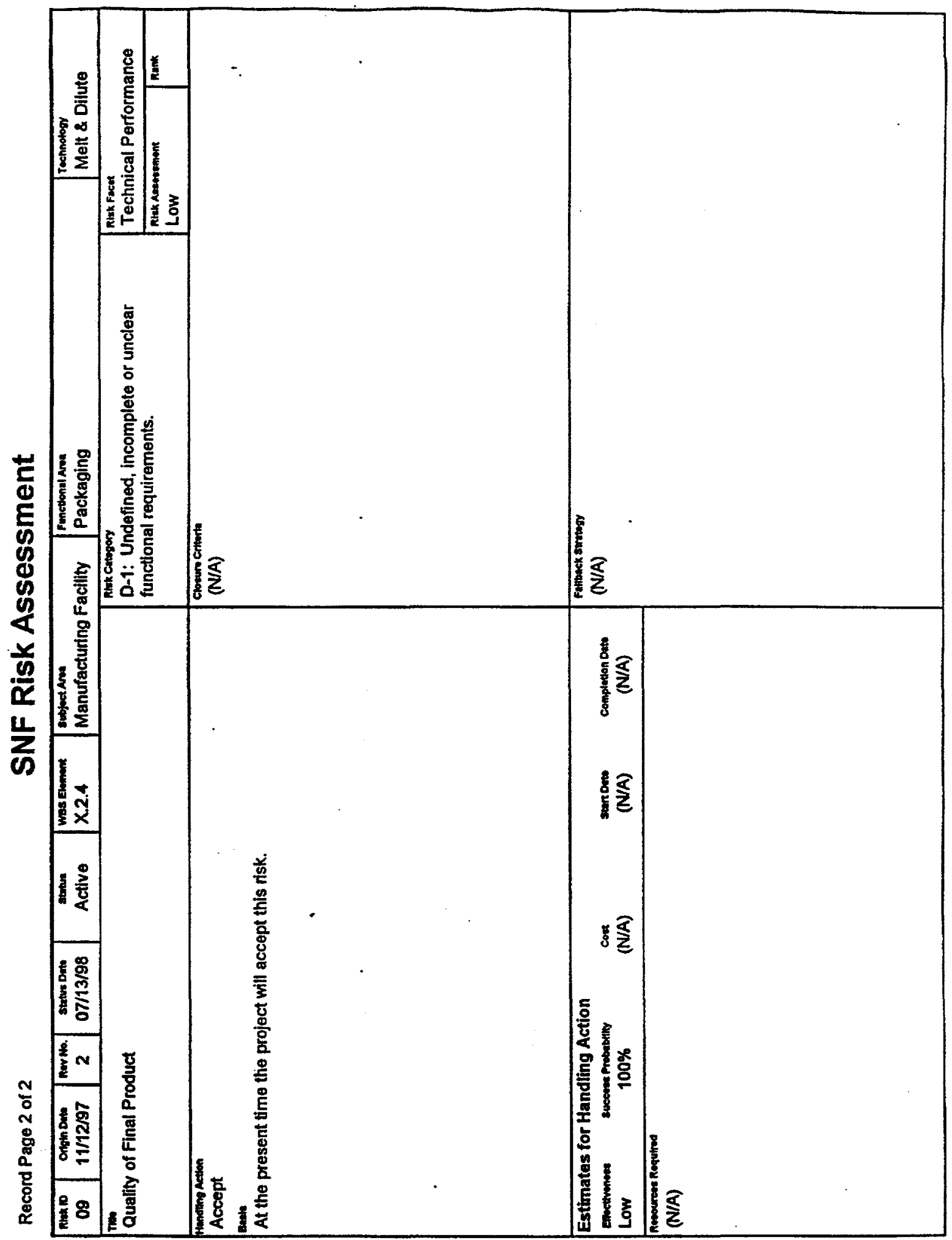




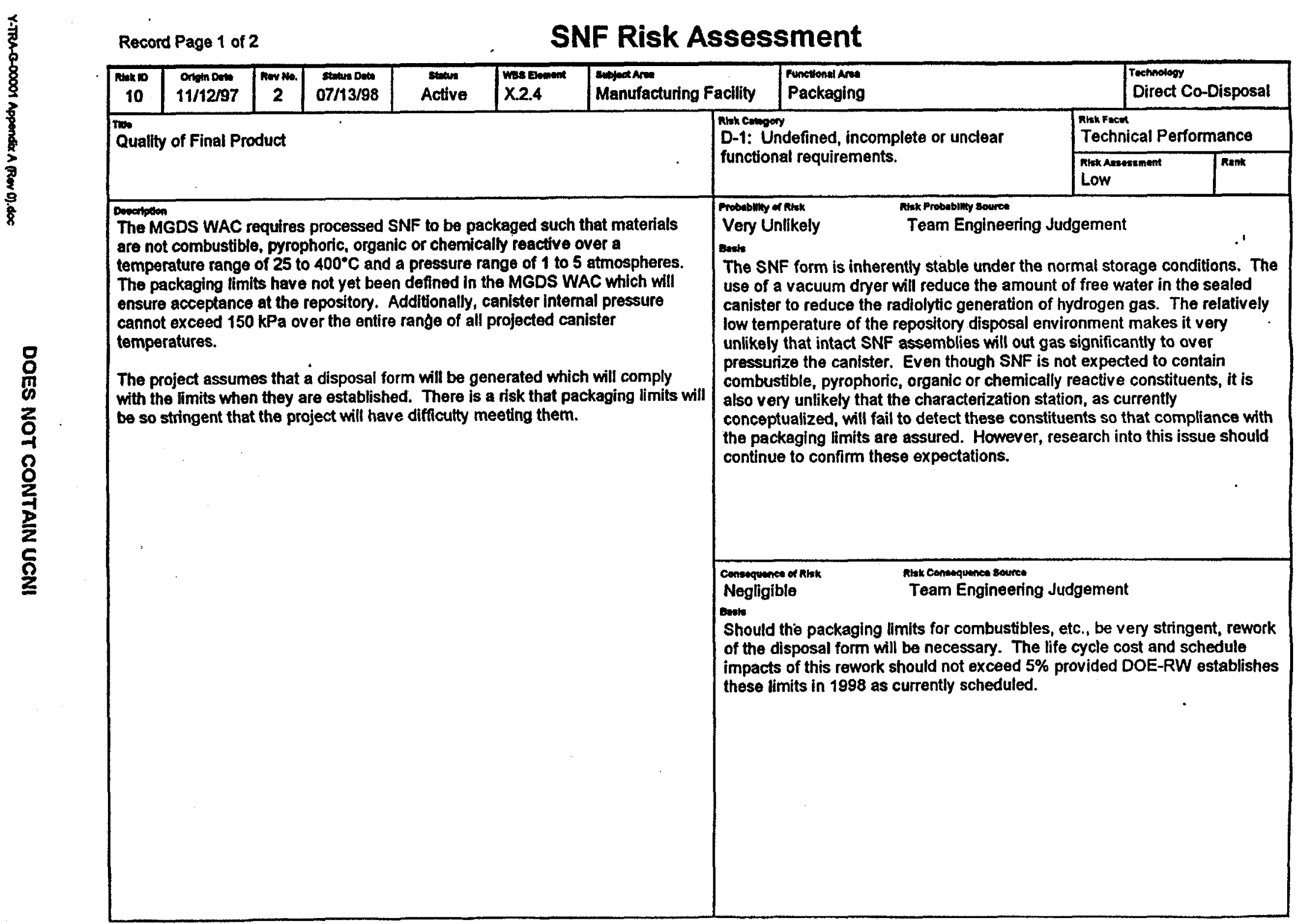




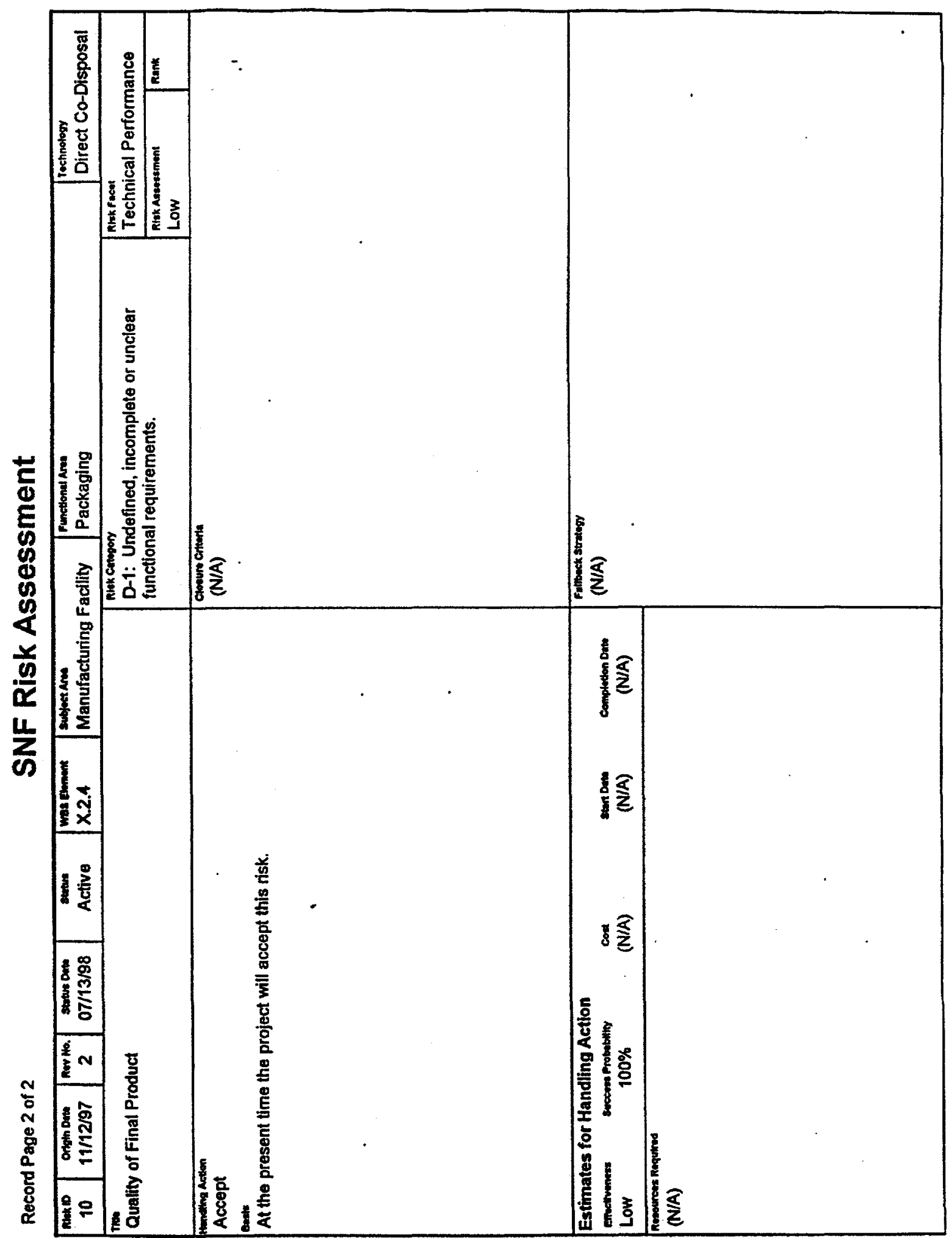


SNF Risk Assessment

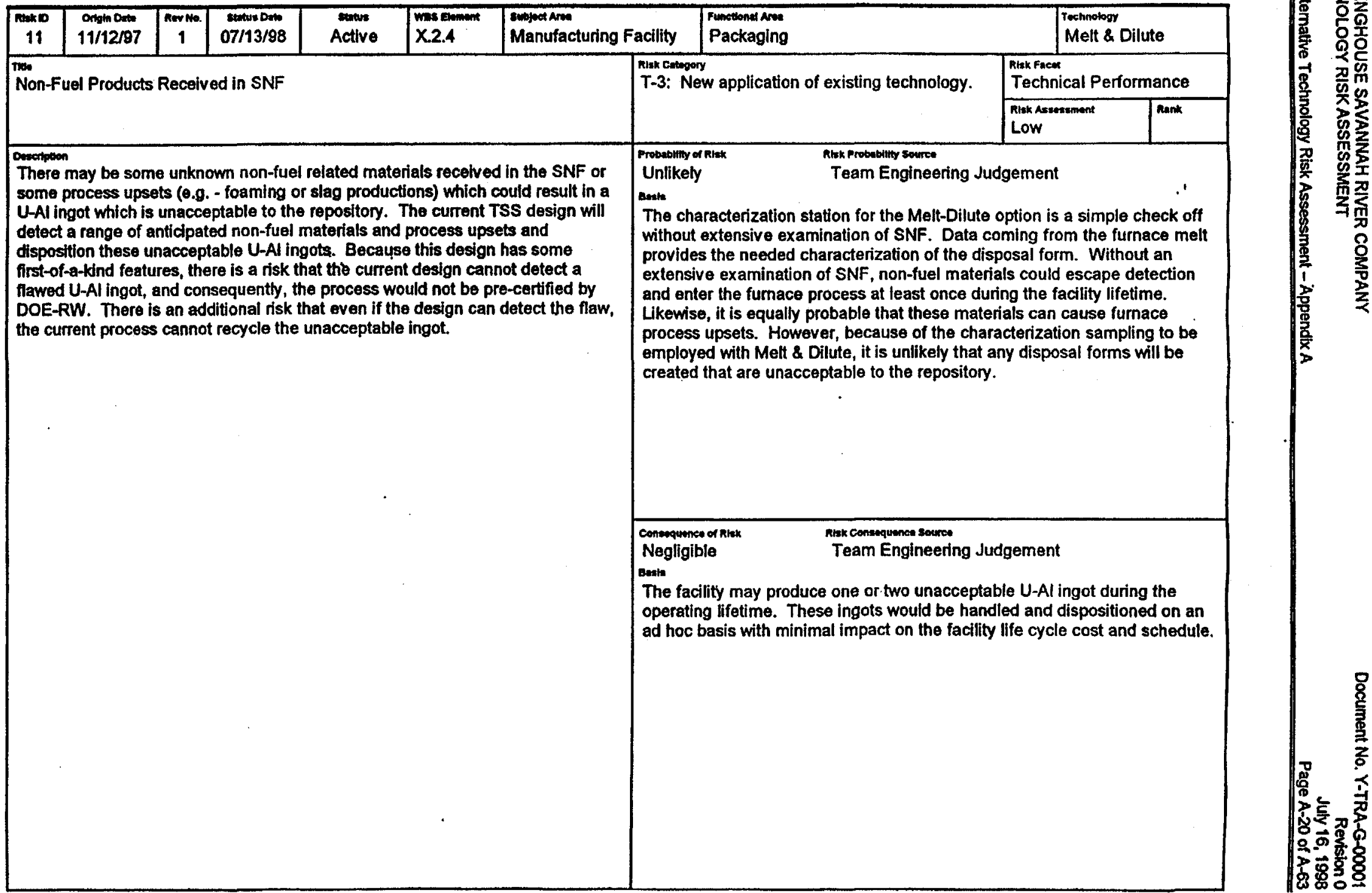




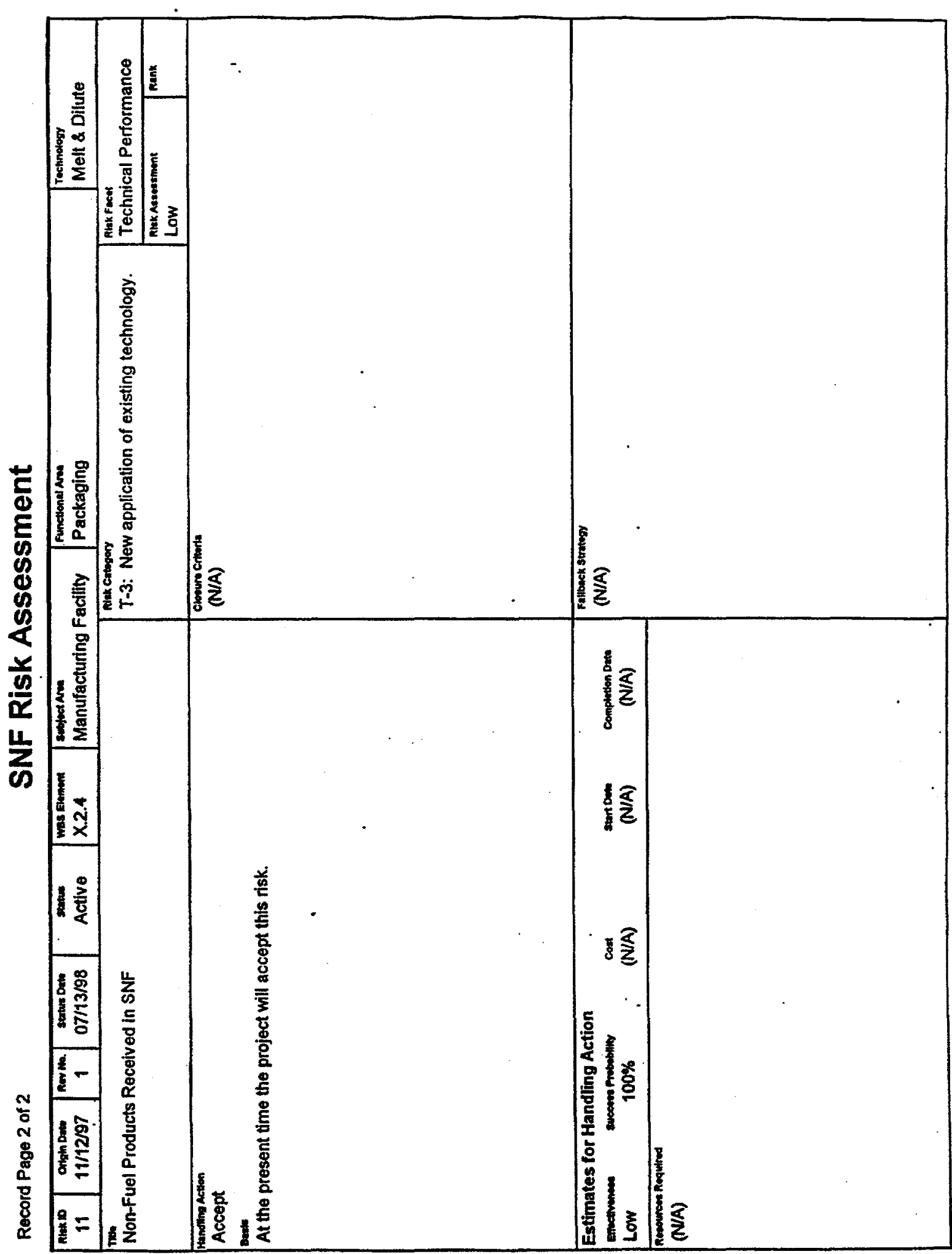




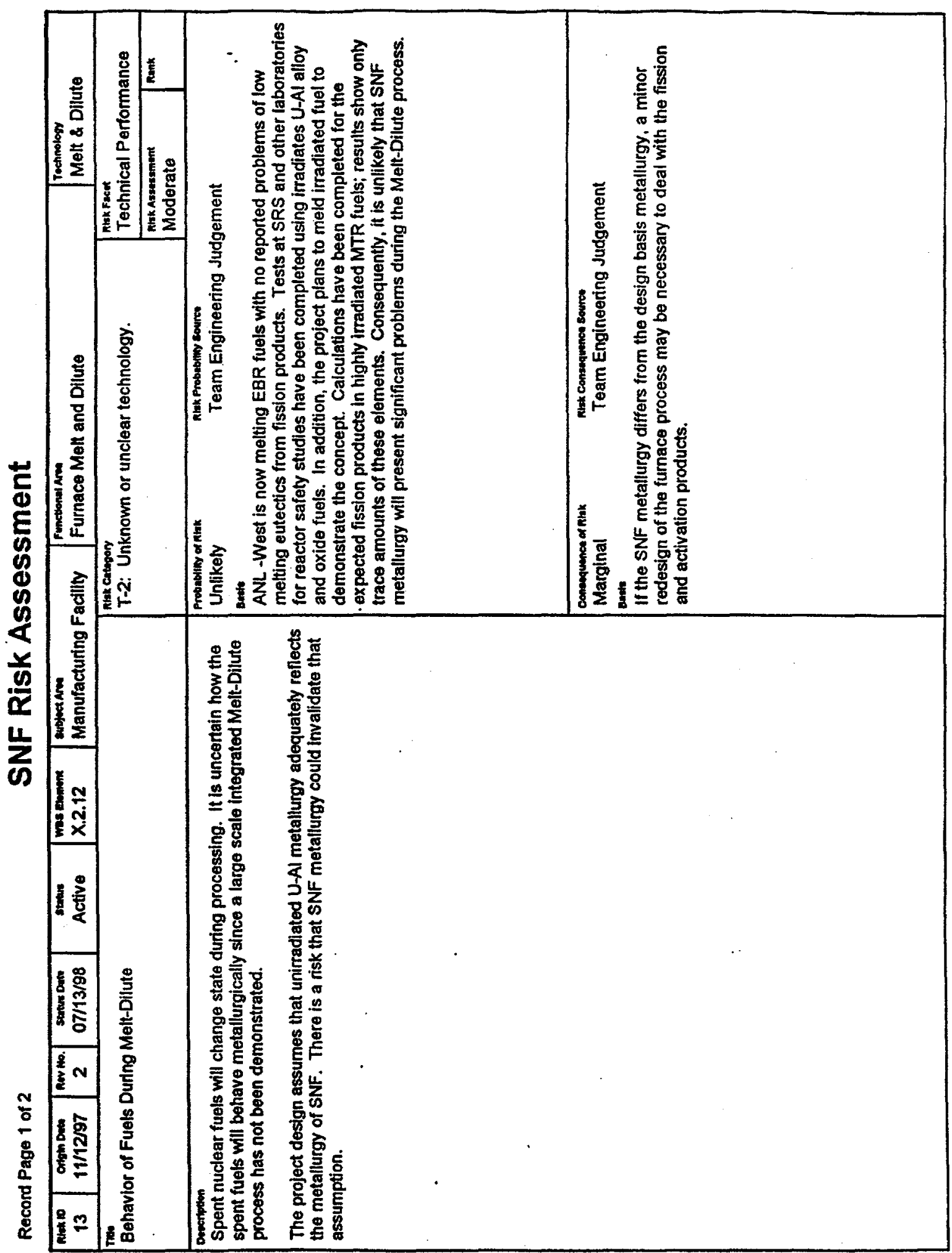




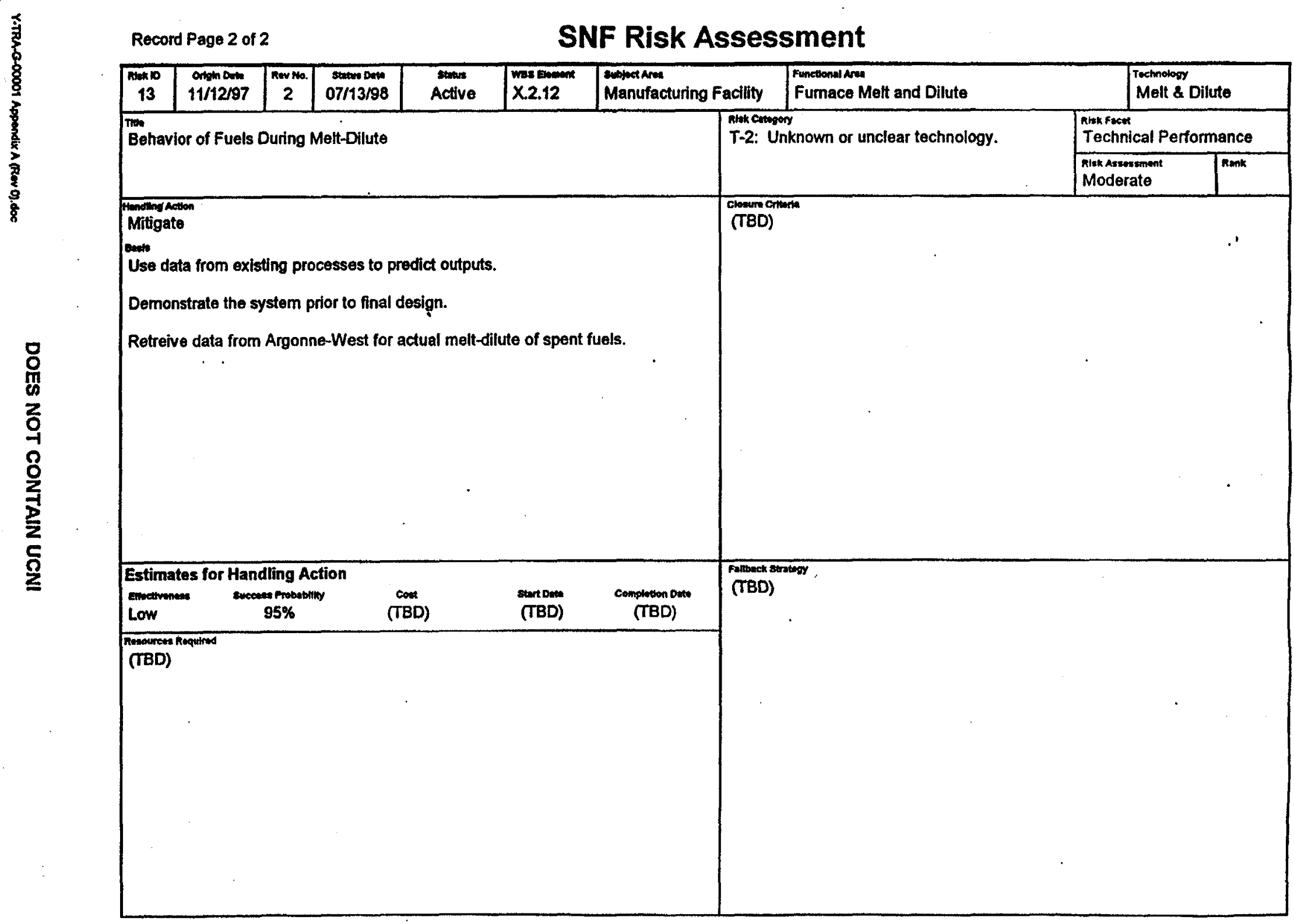




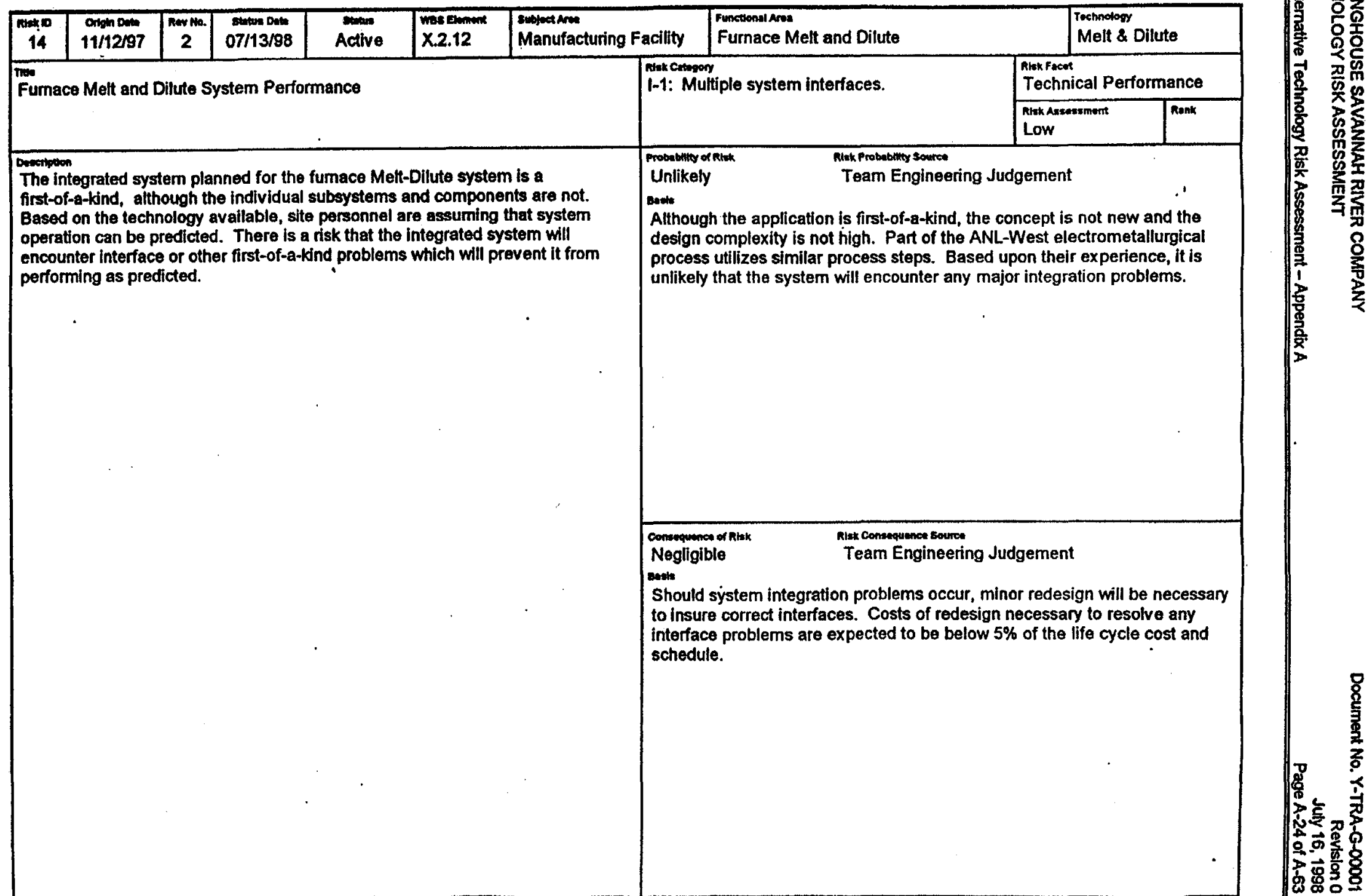




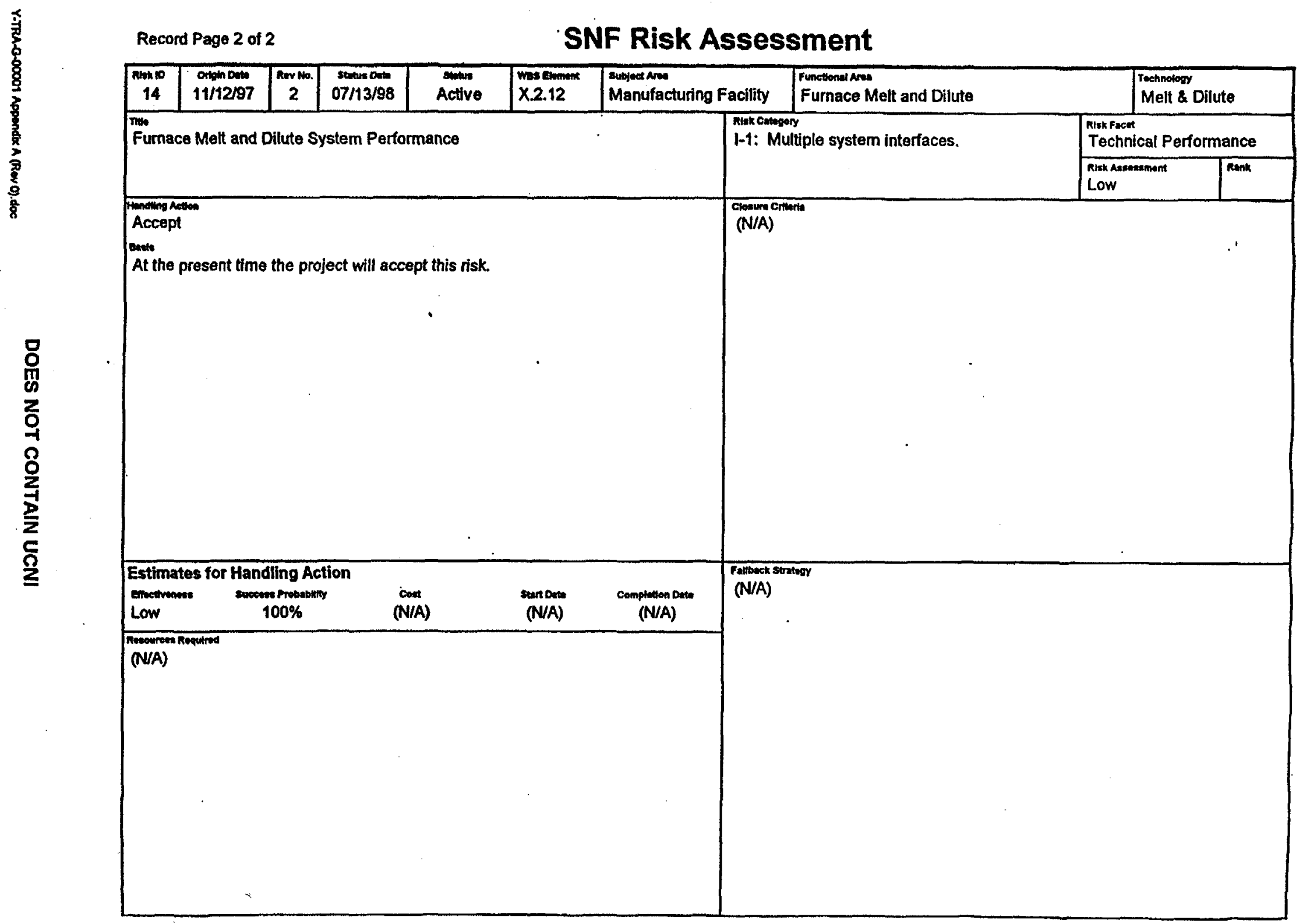




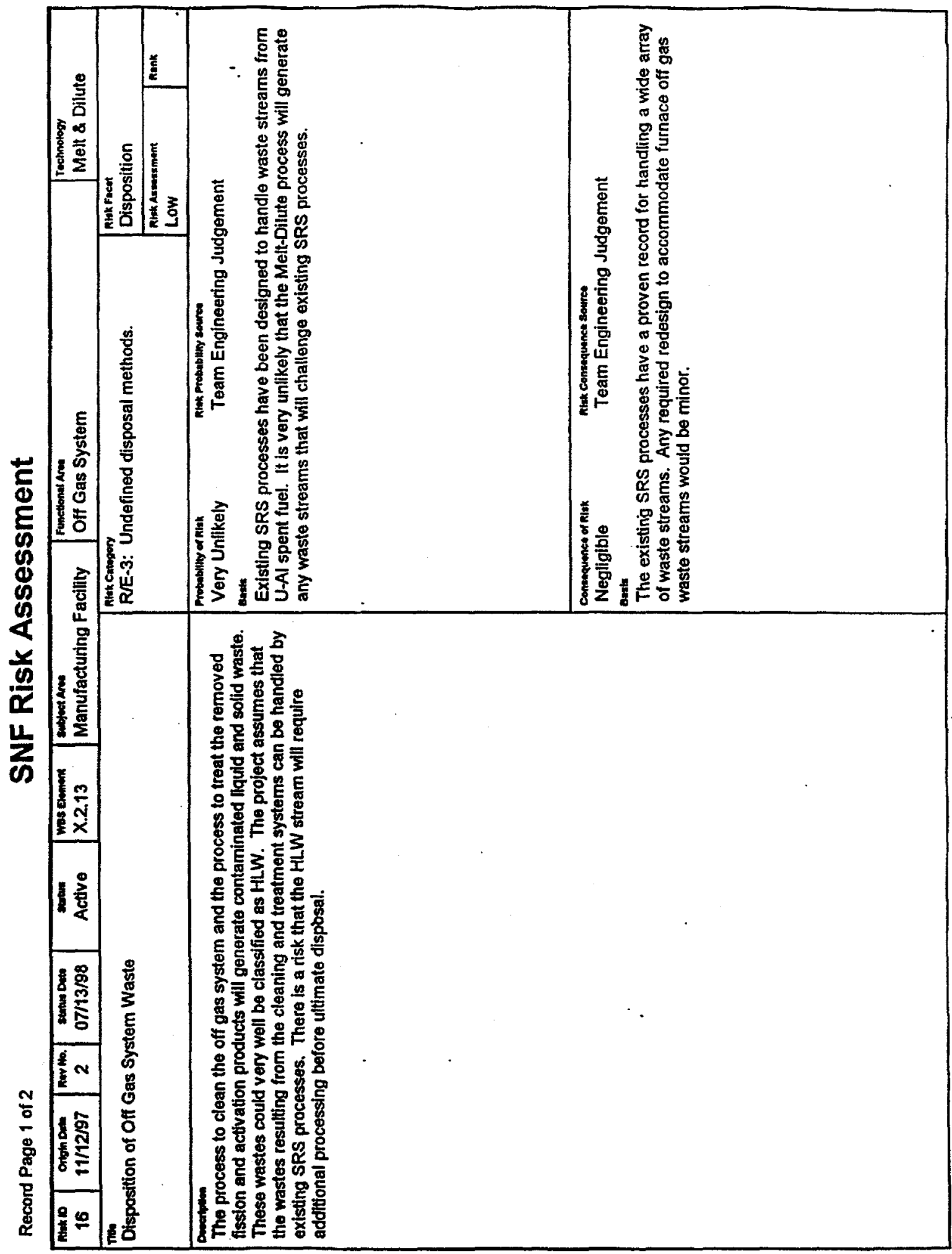




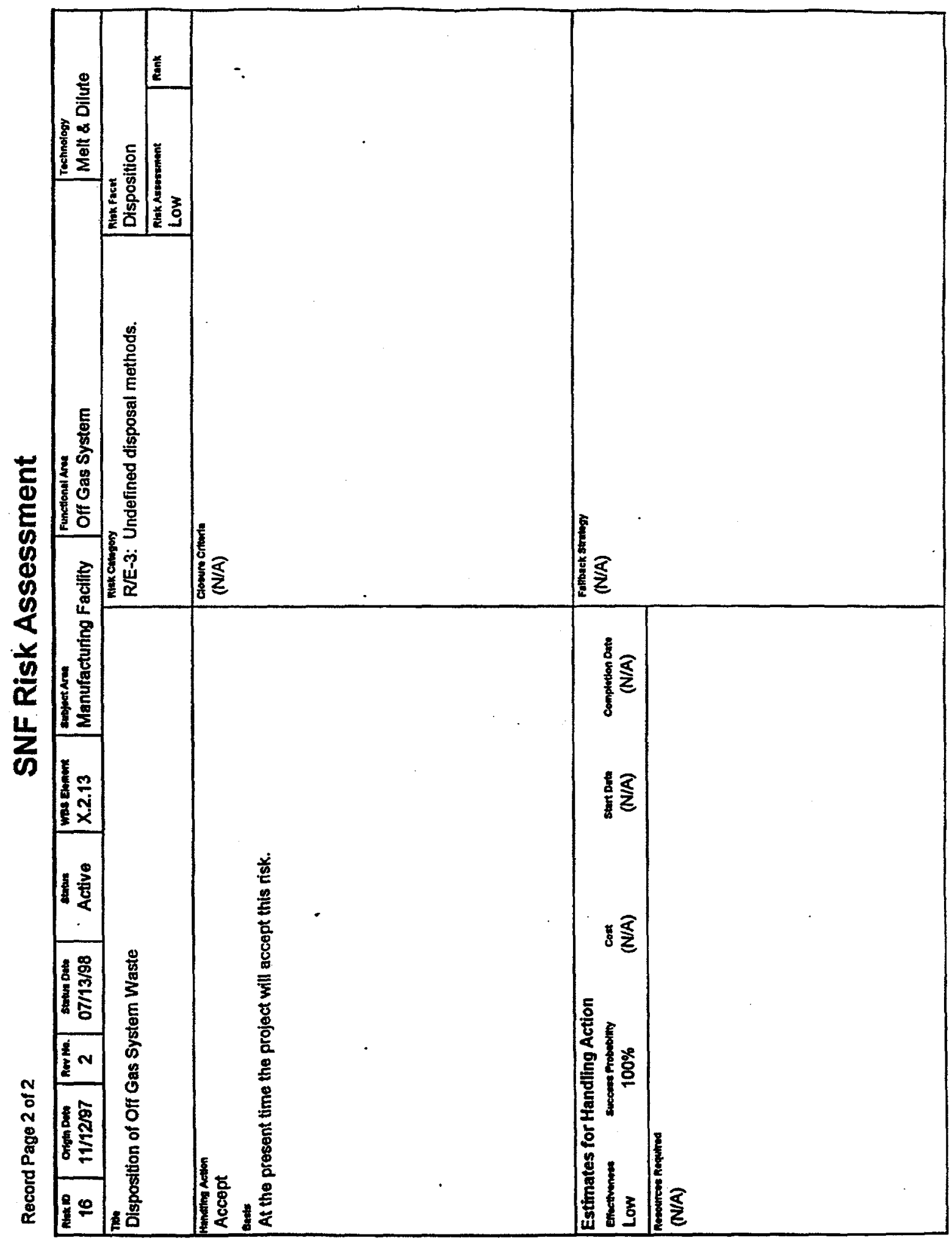




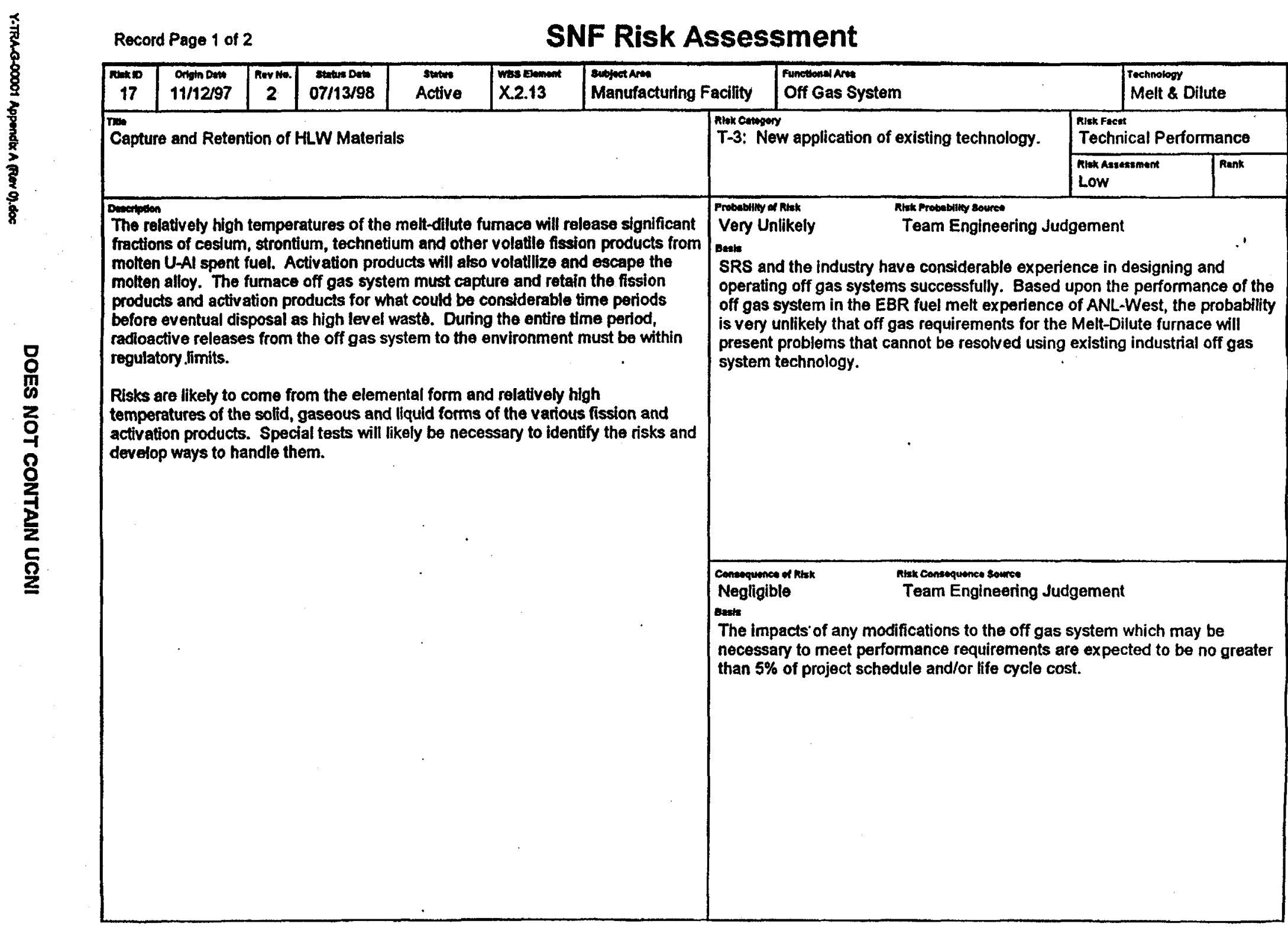




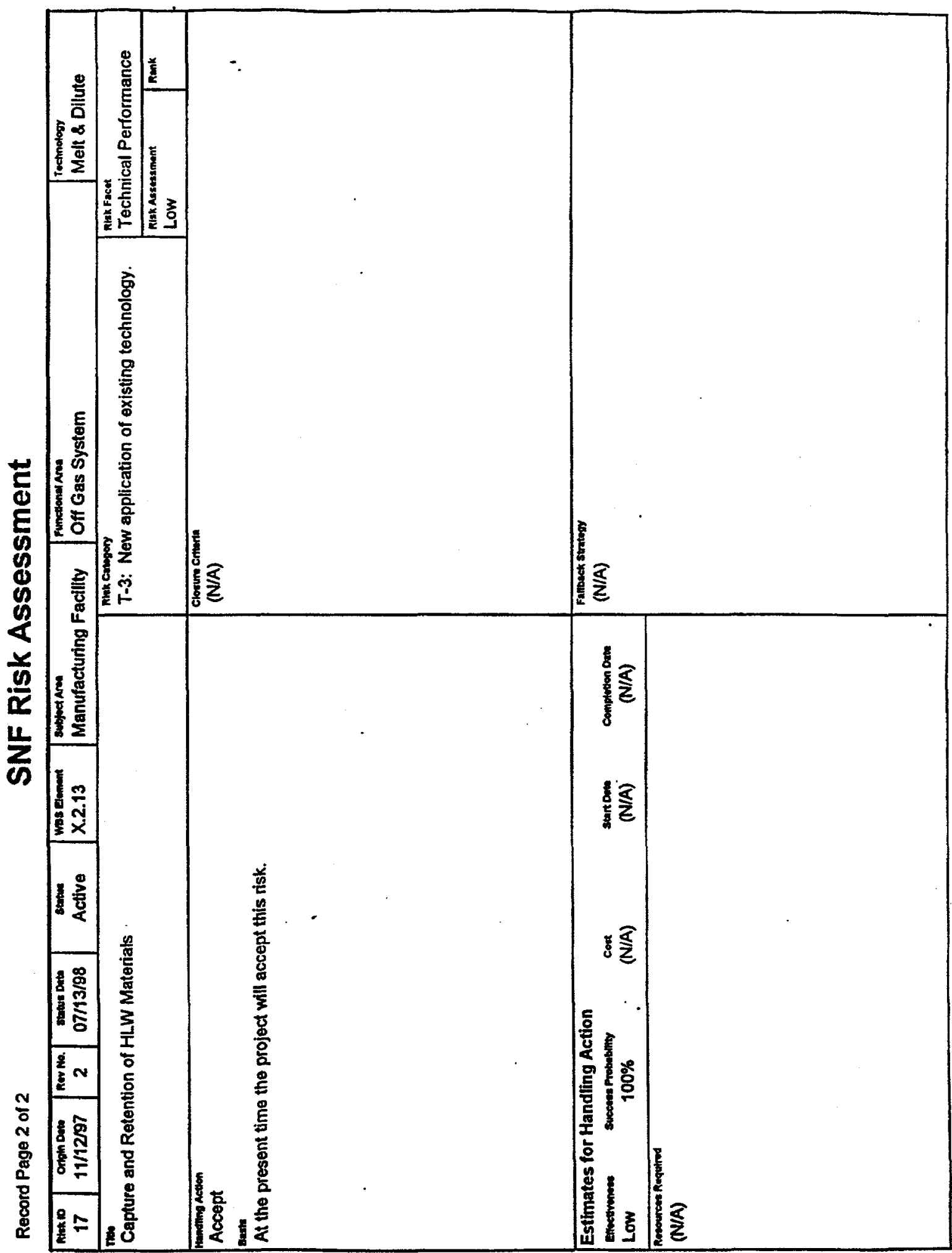




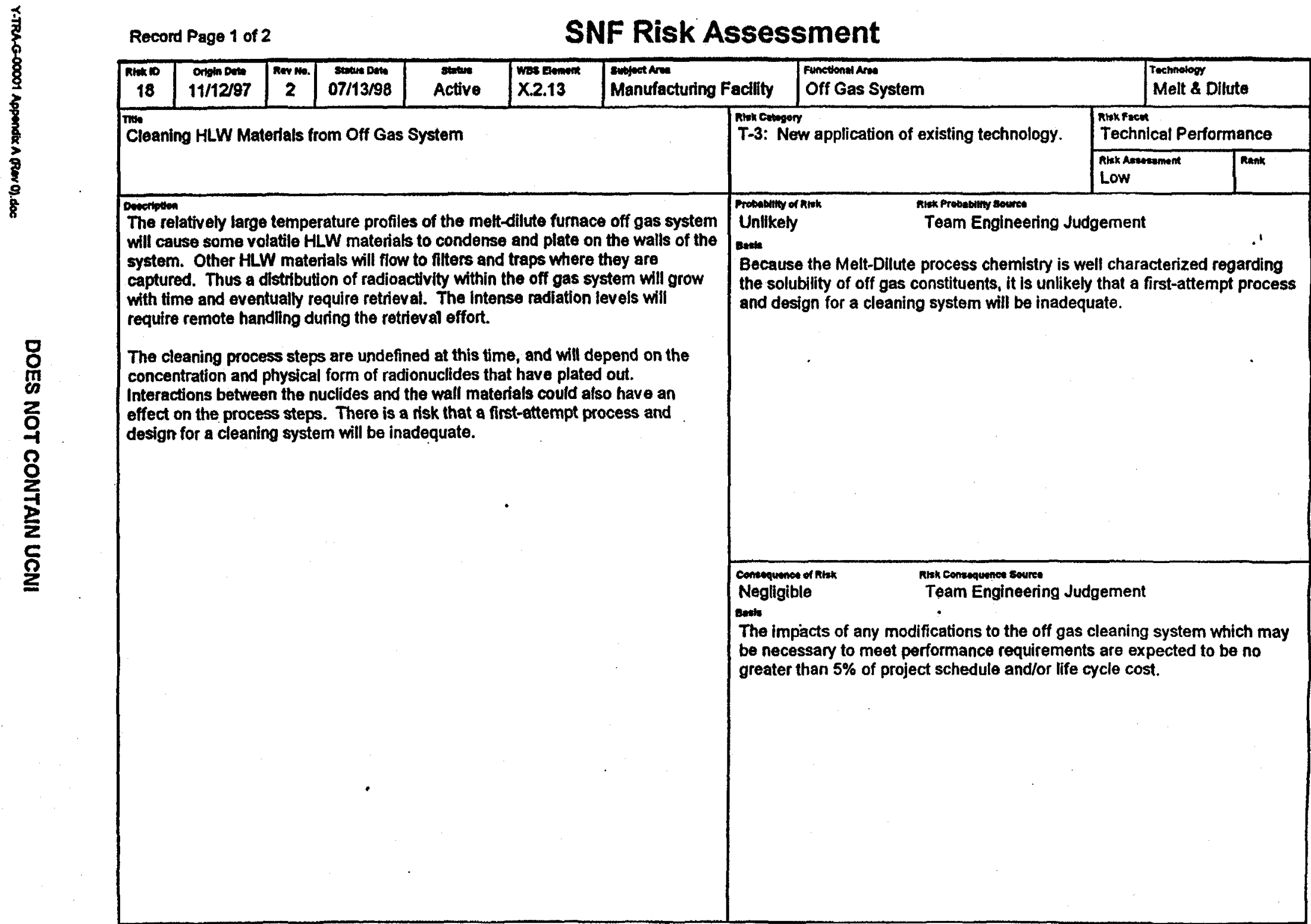




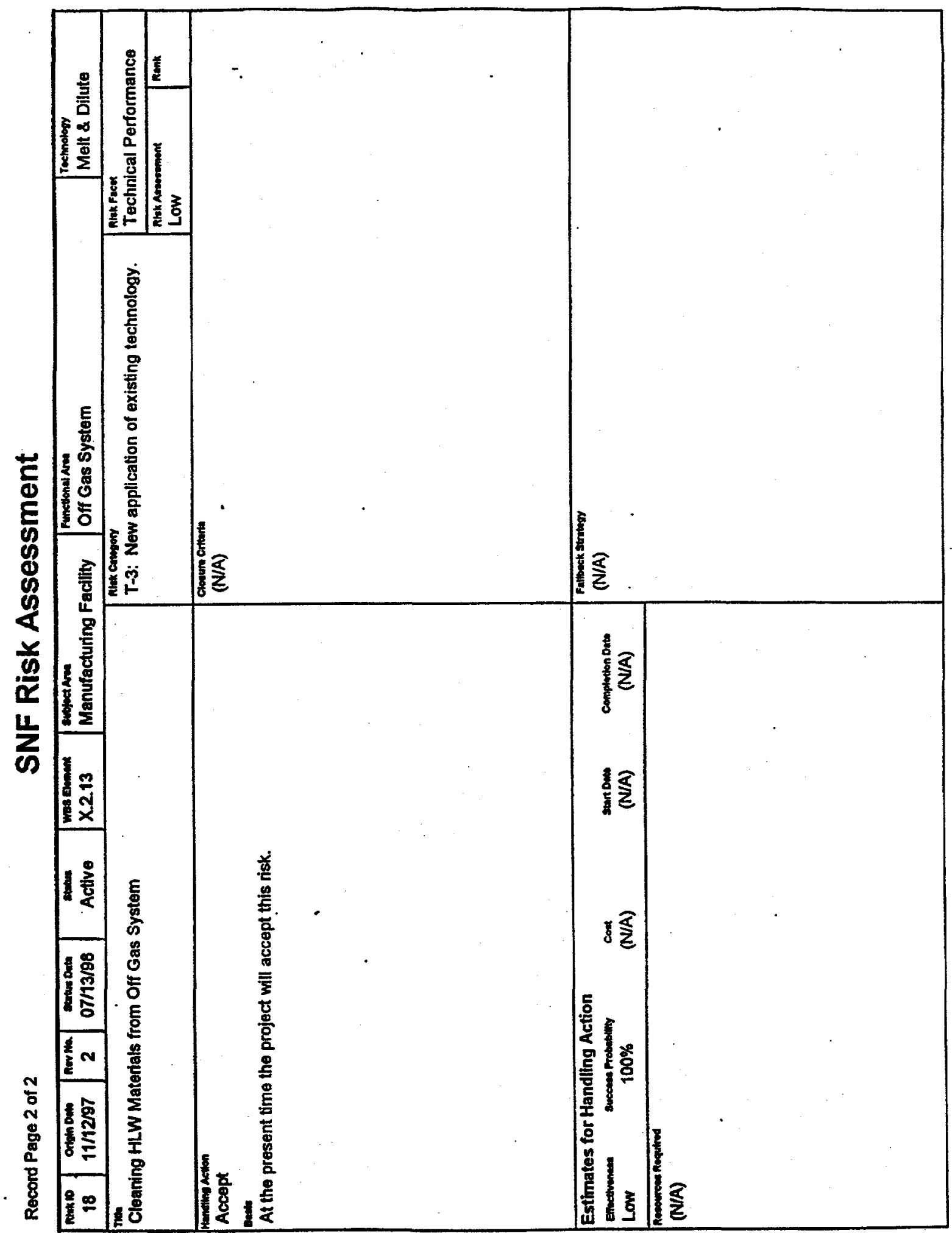




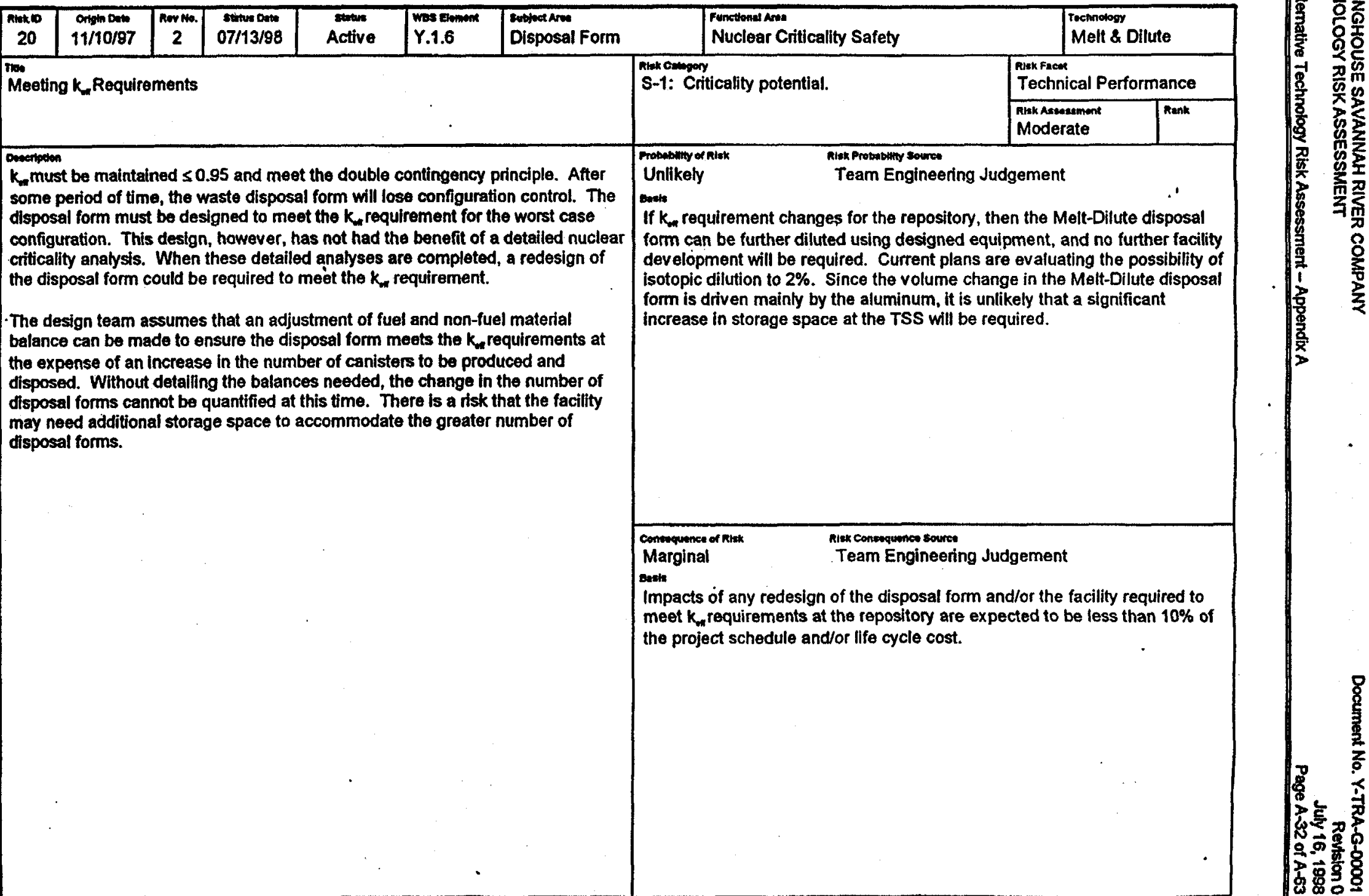




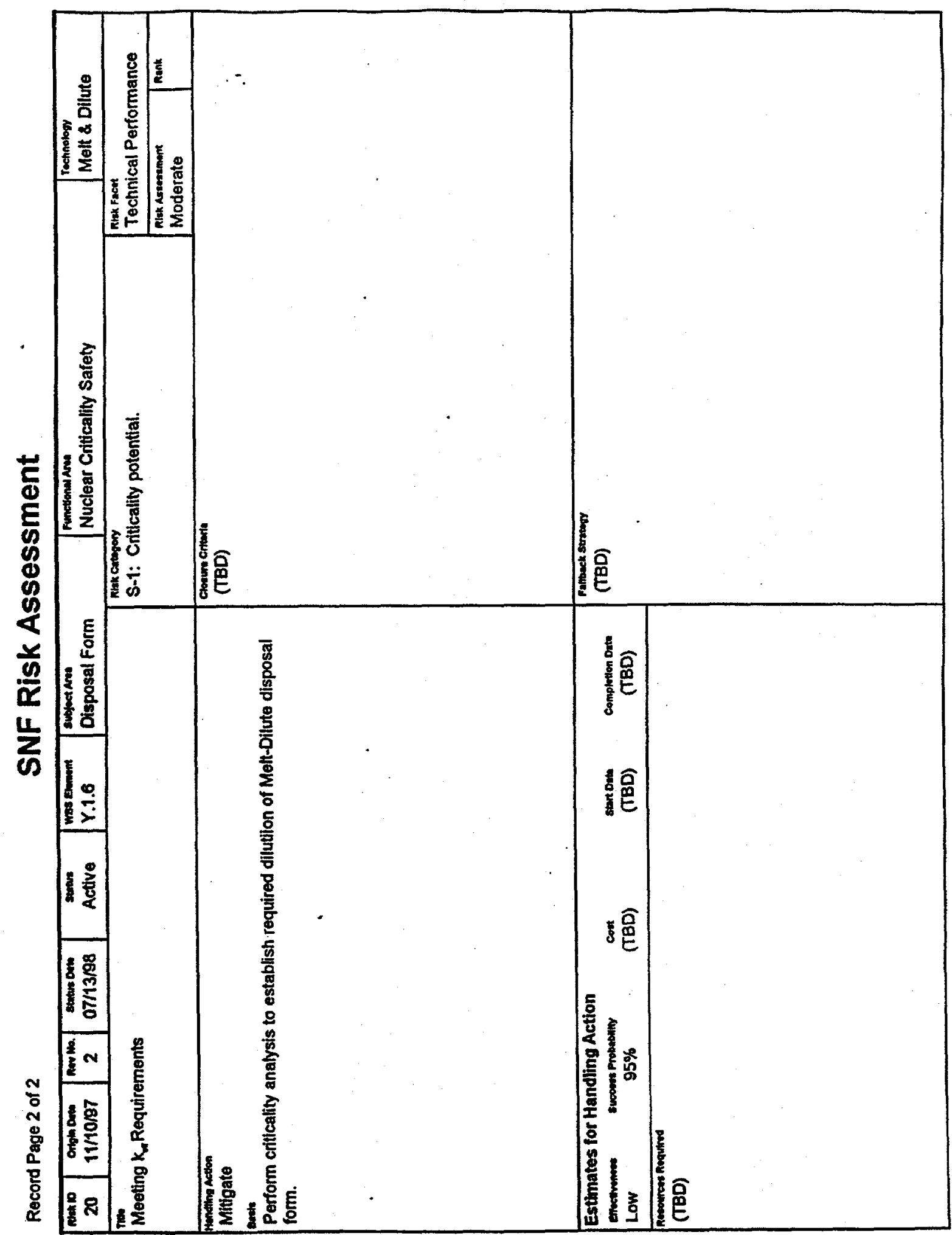




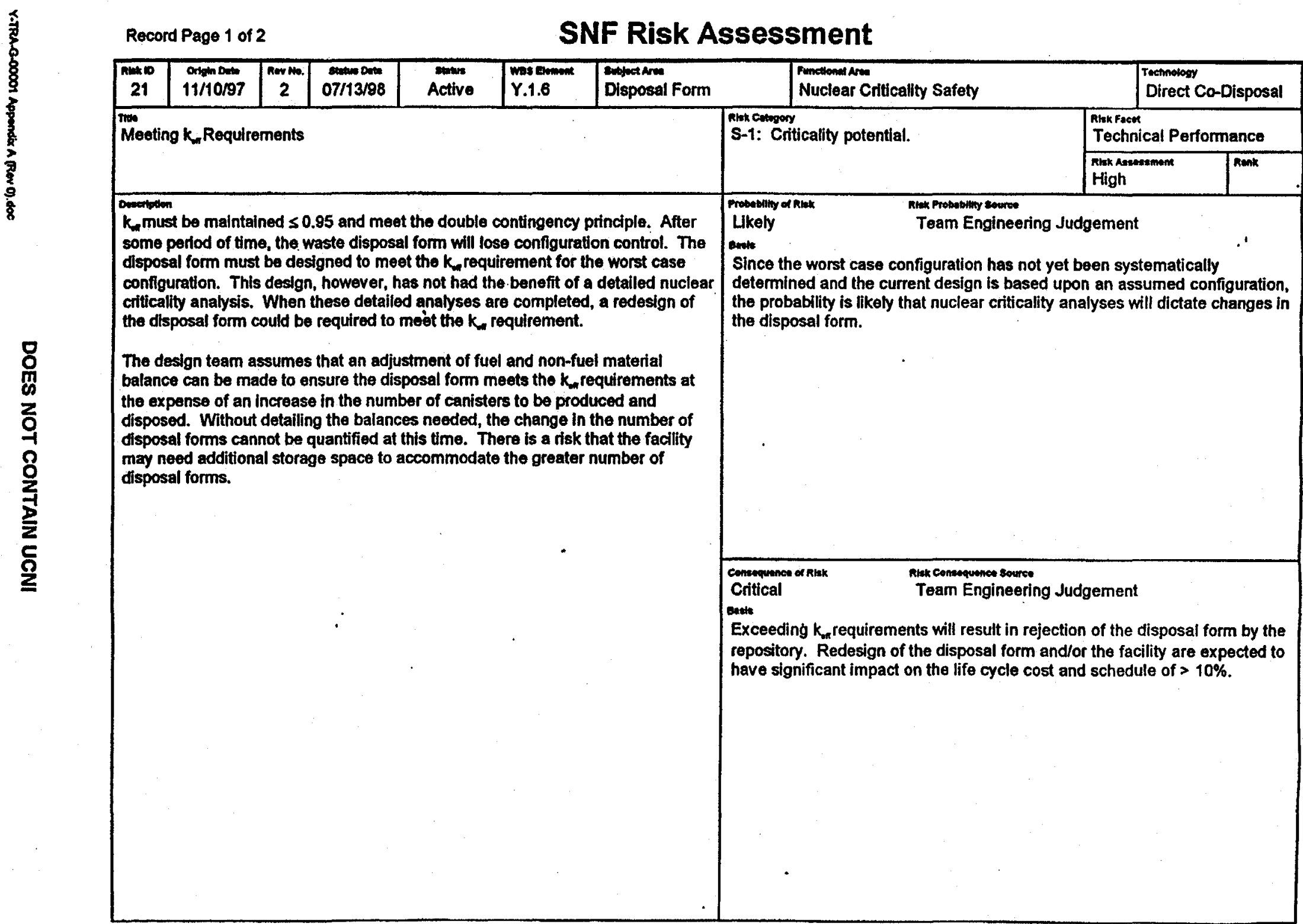




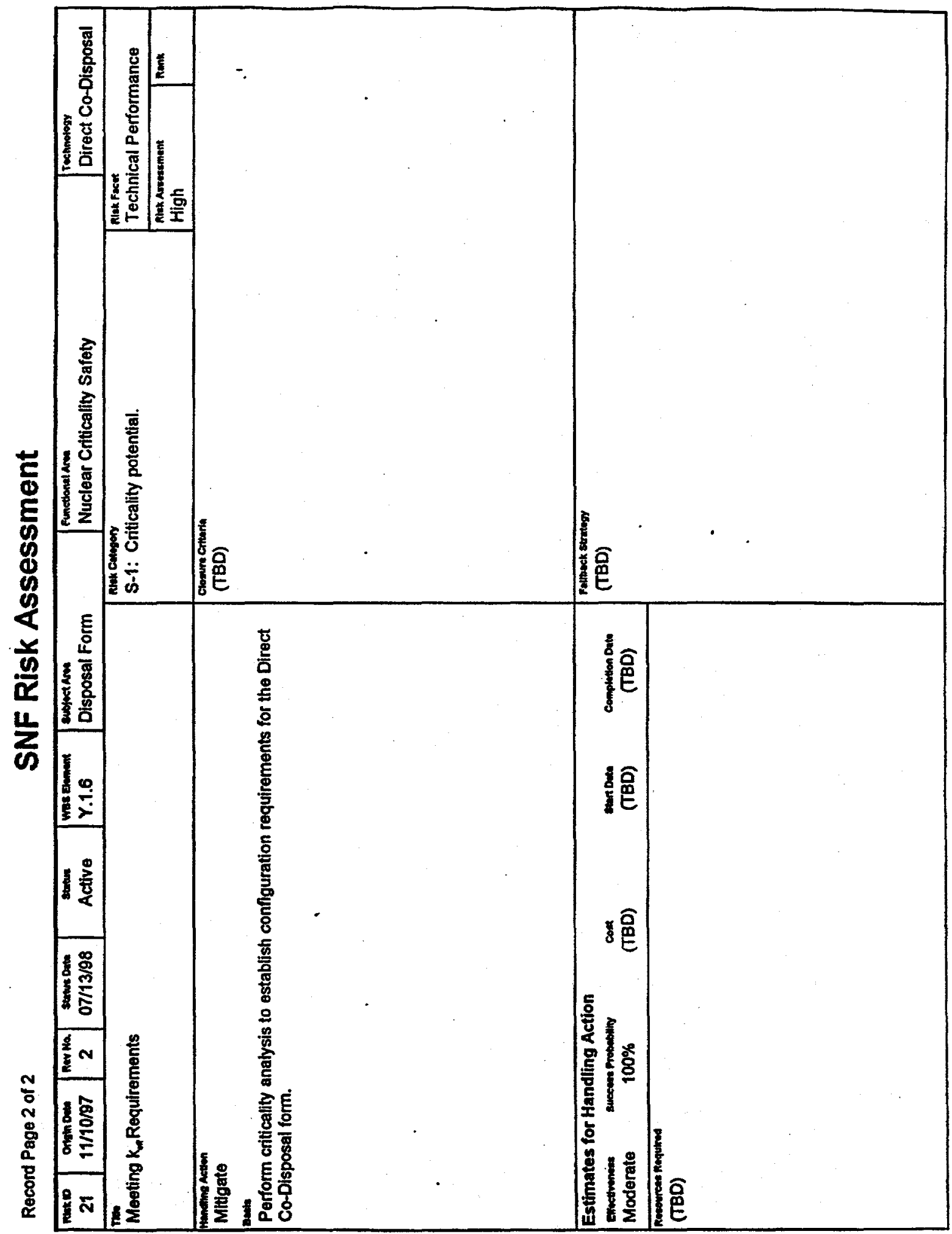




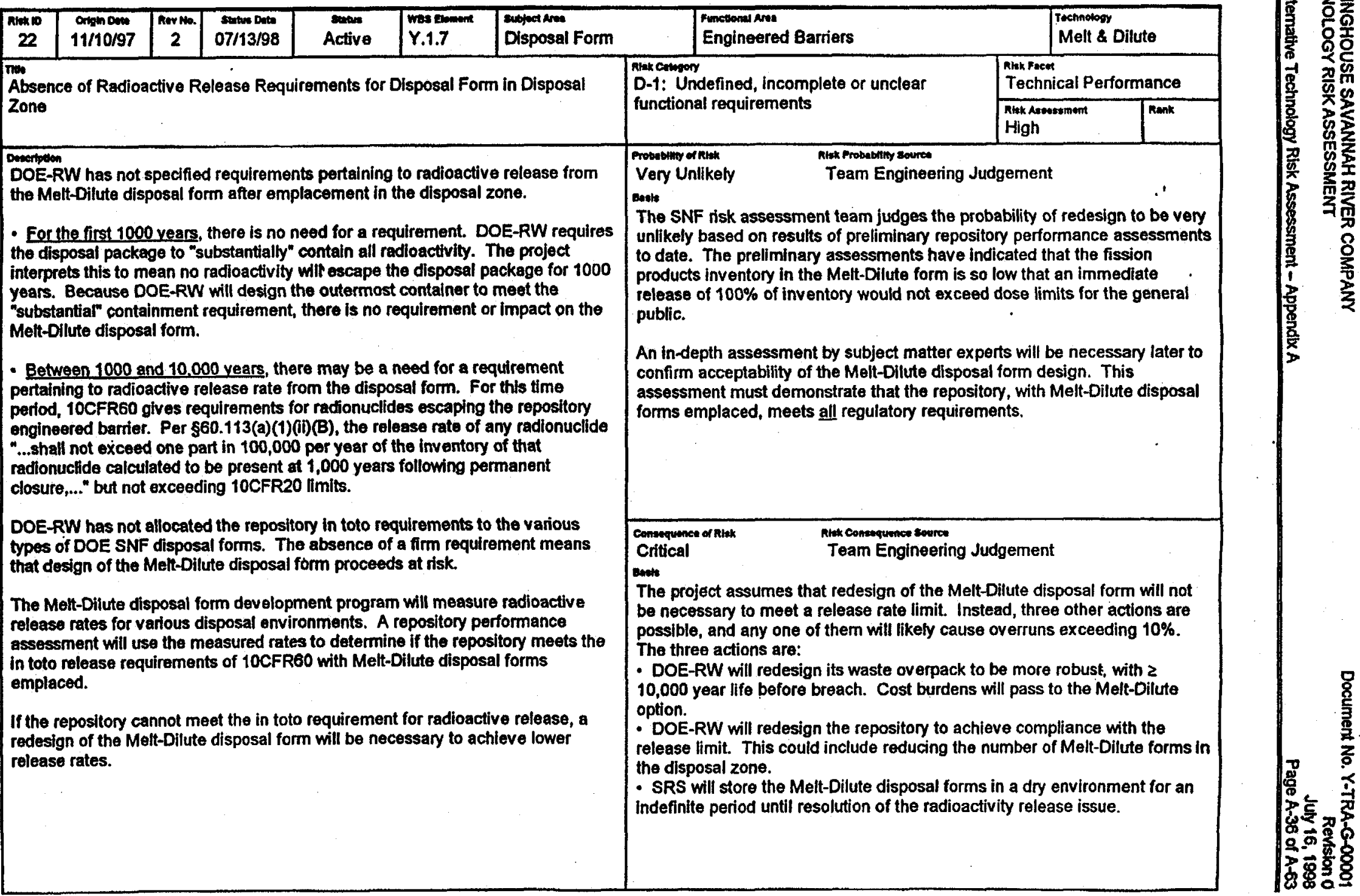




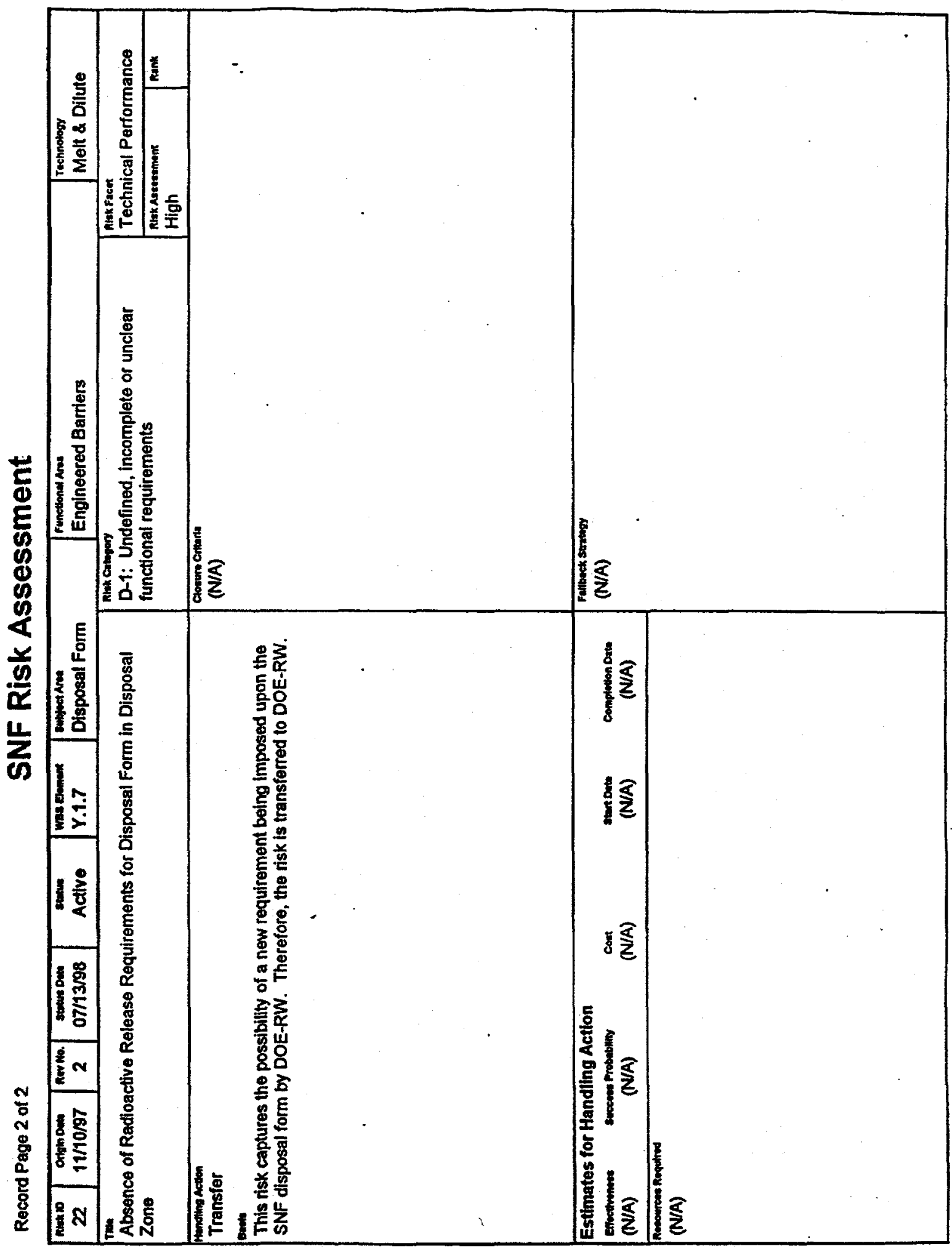




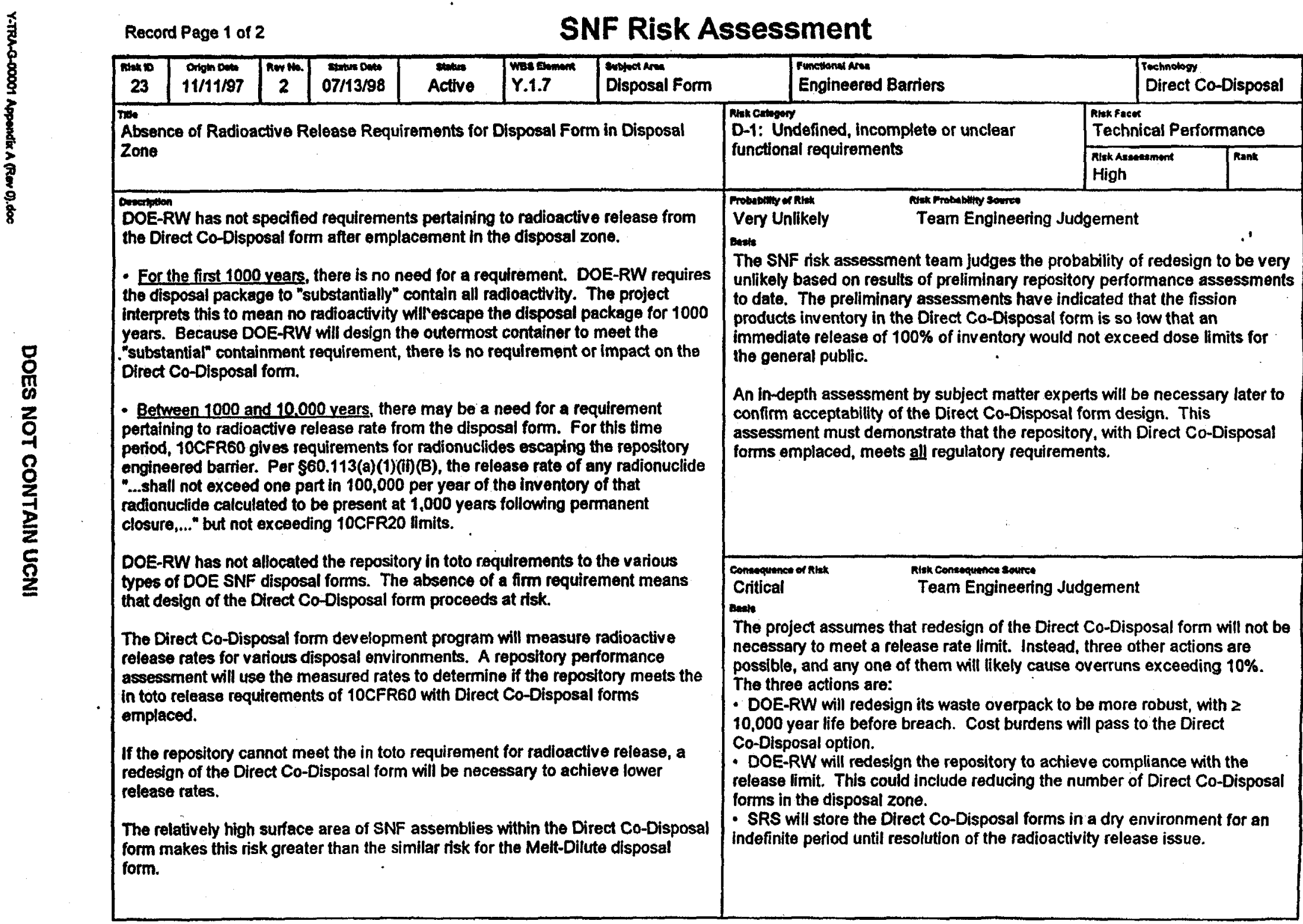




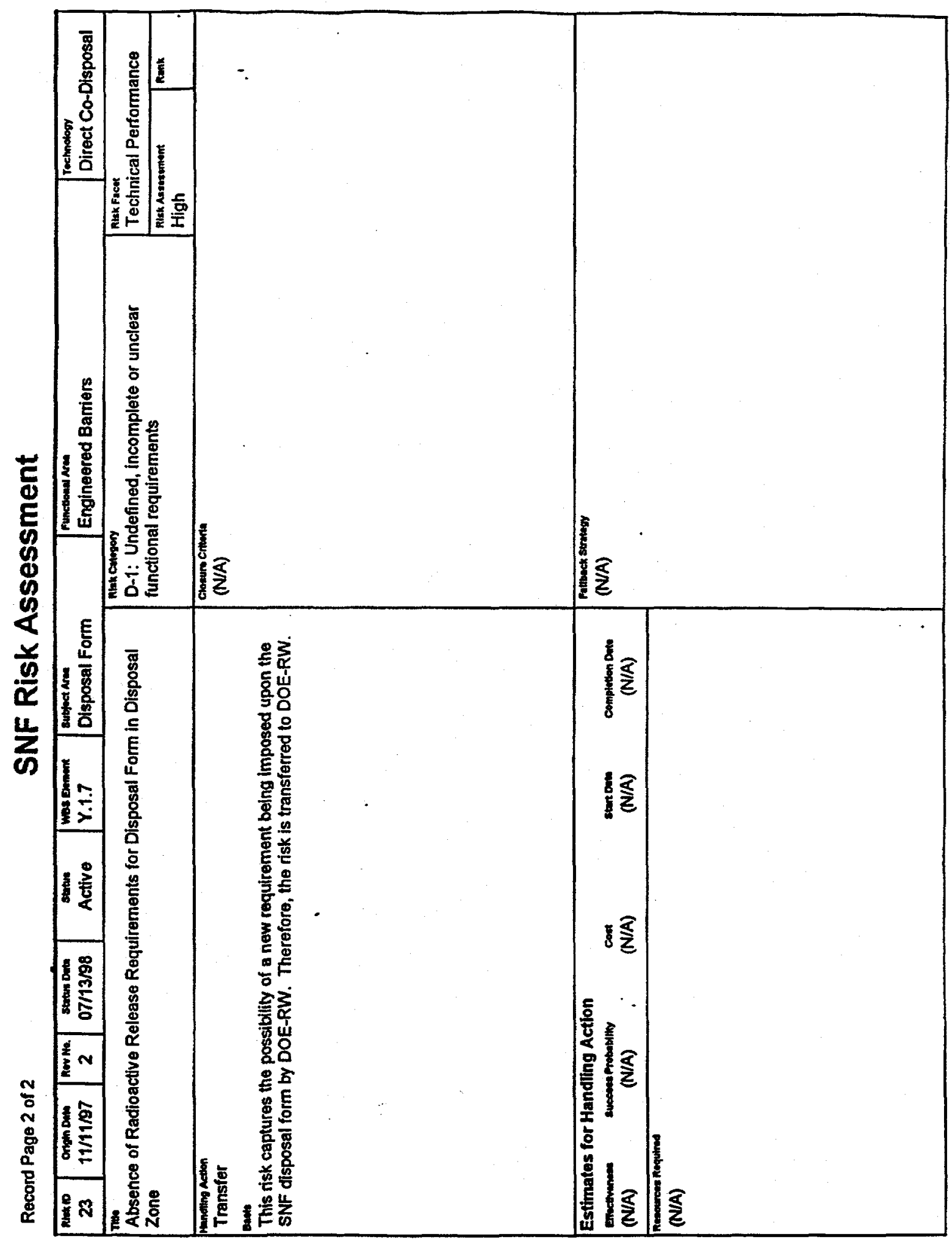




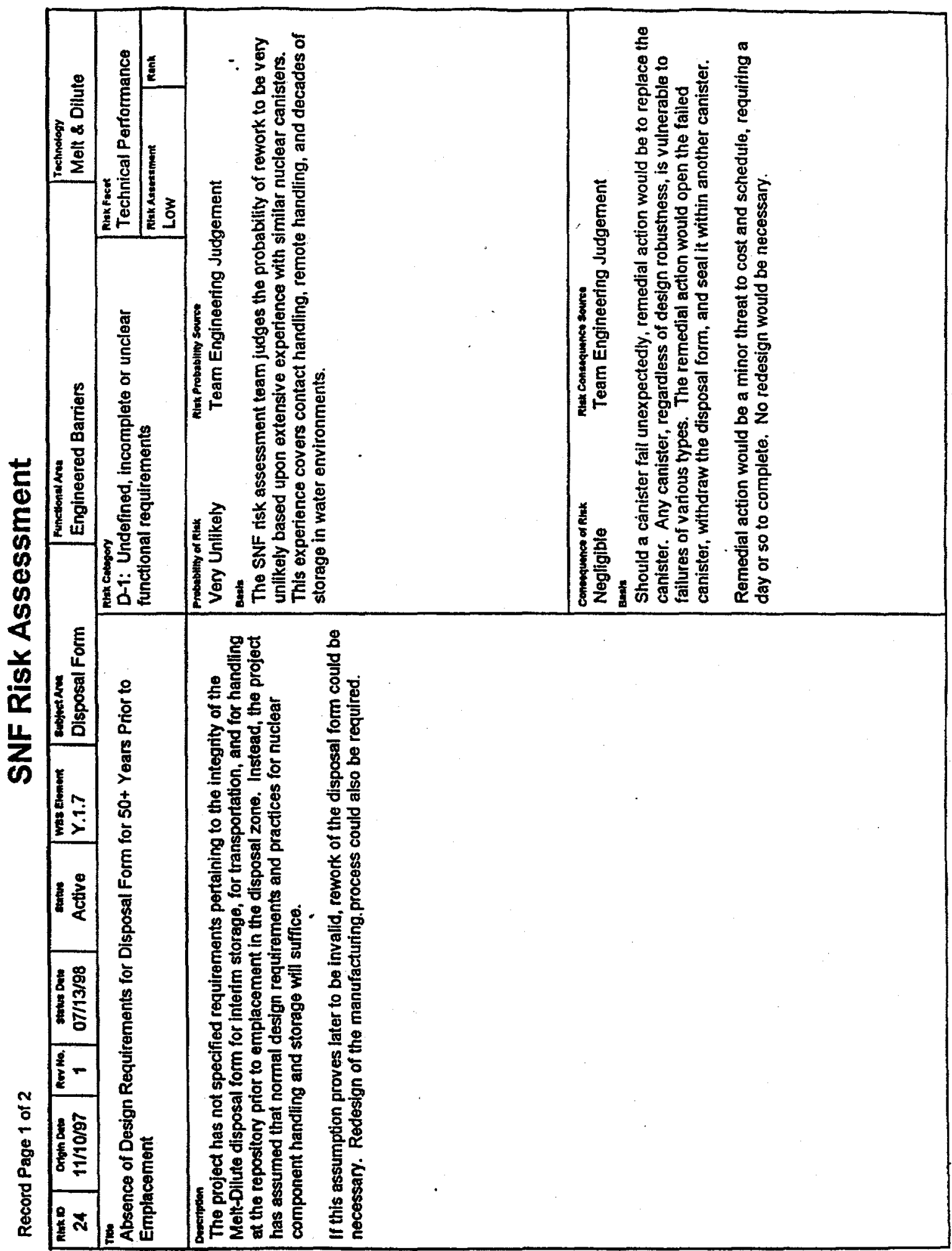




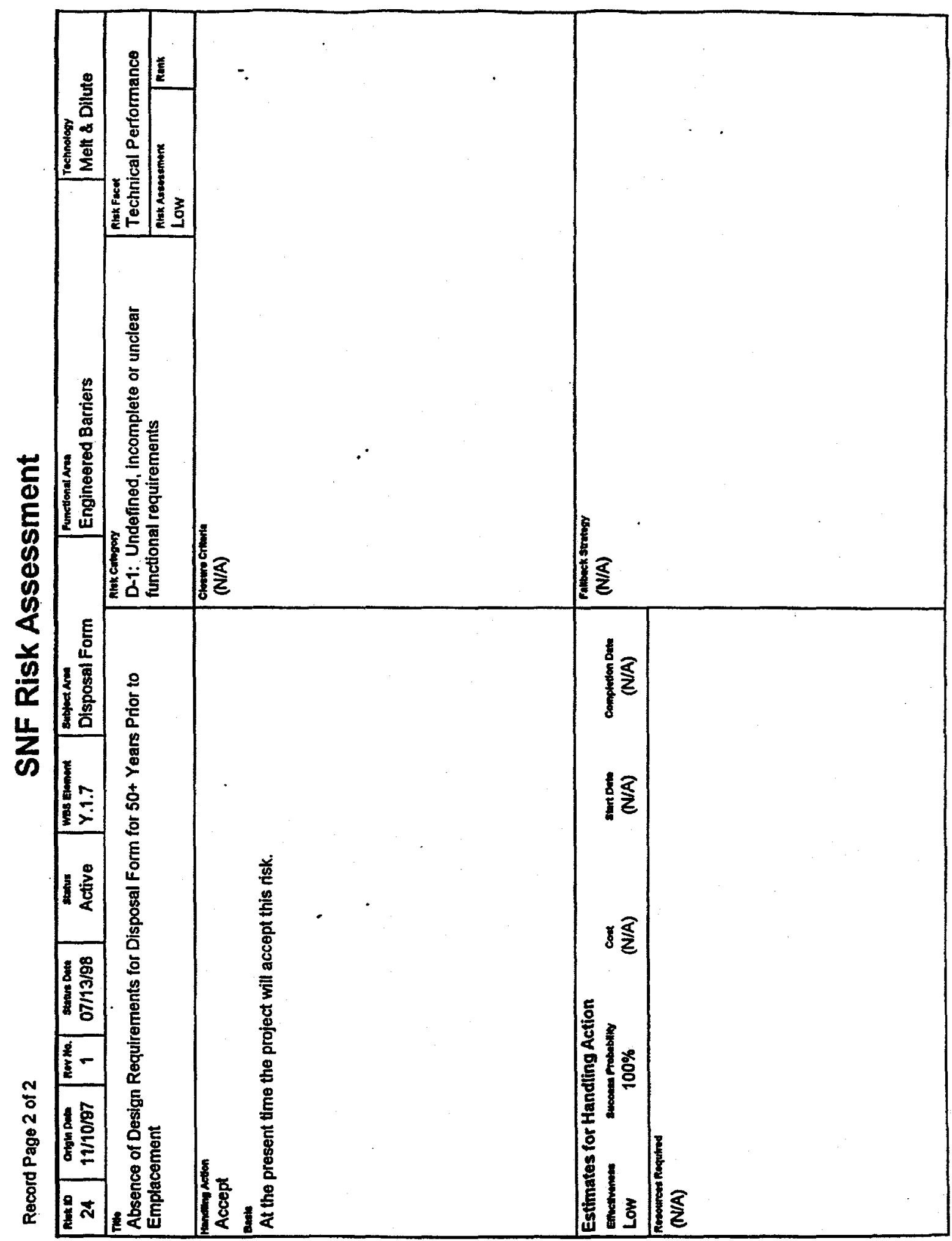




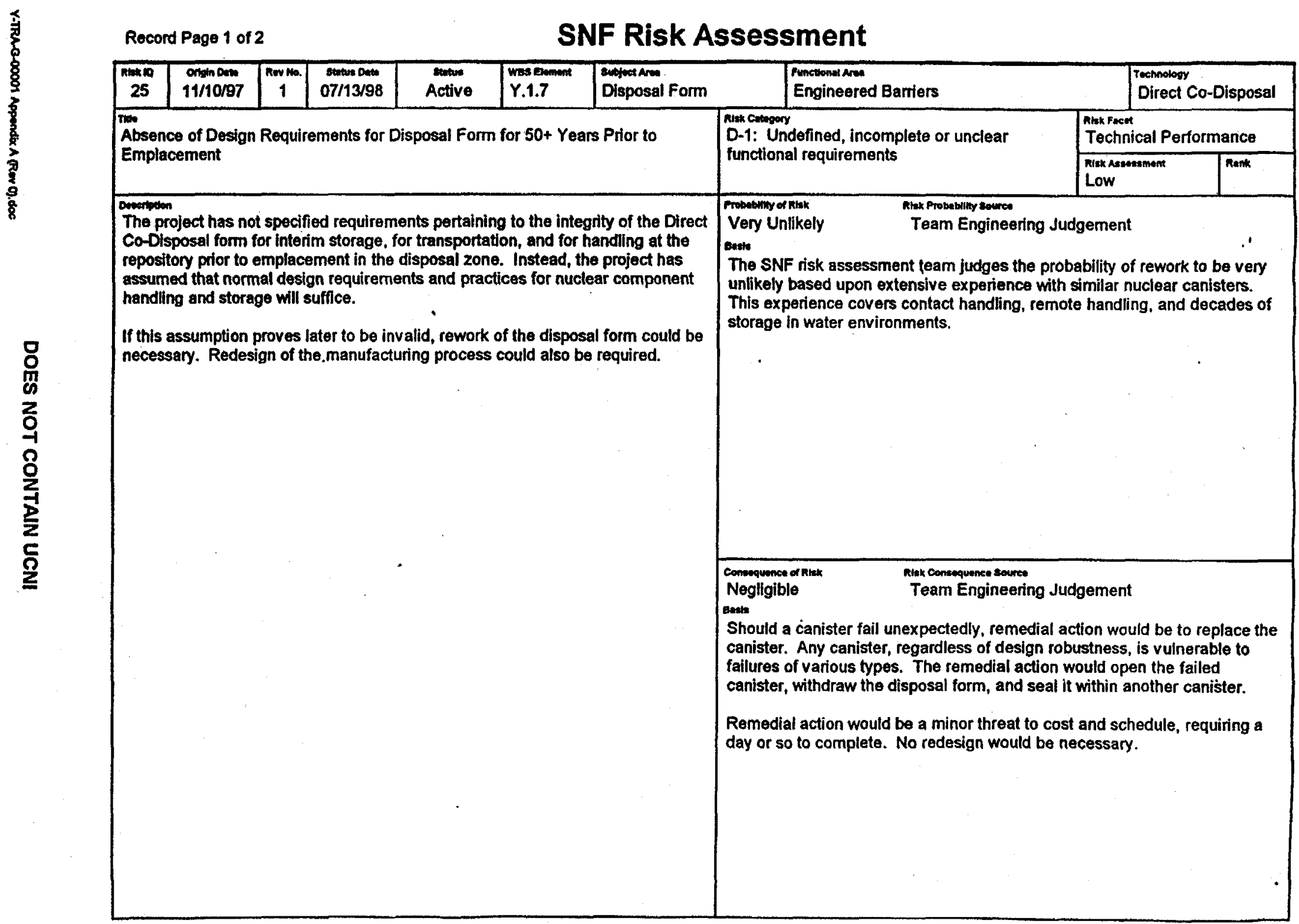




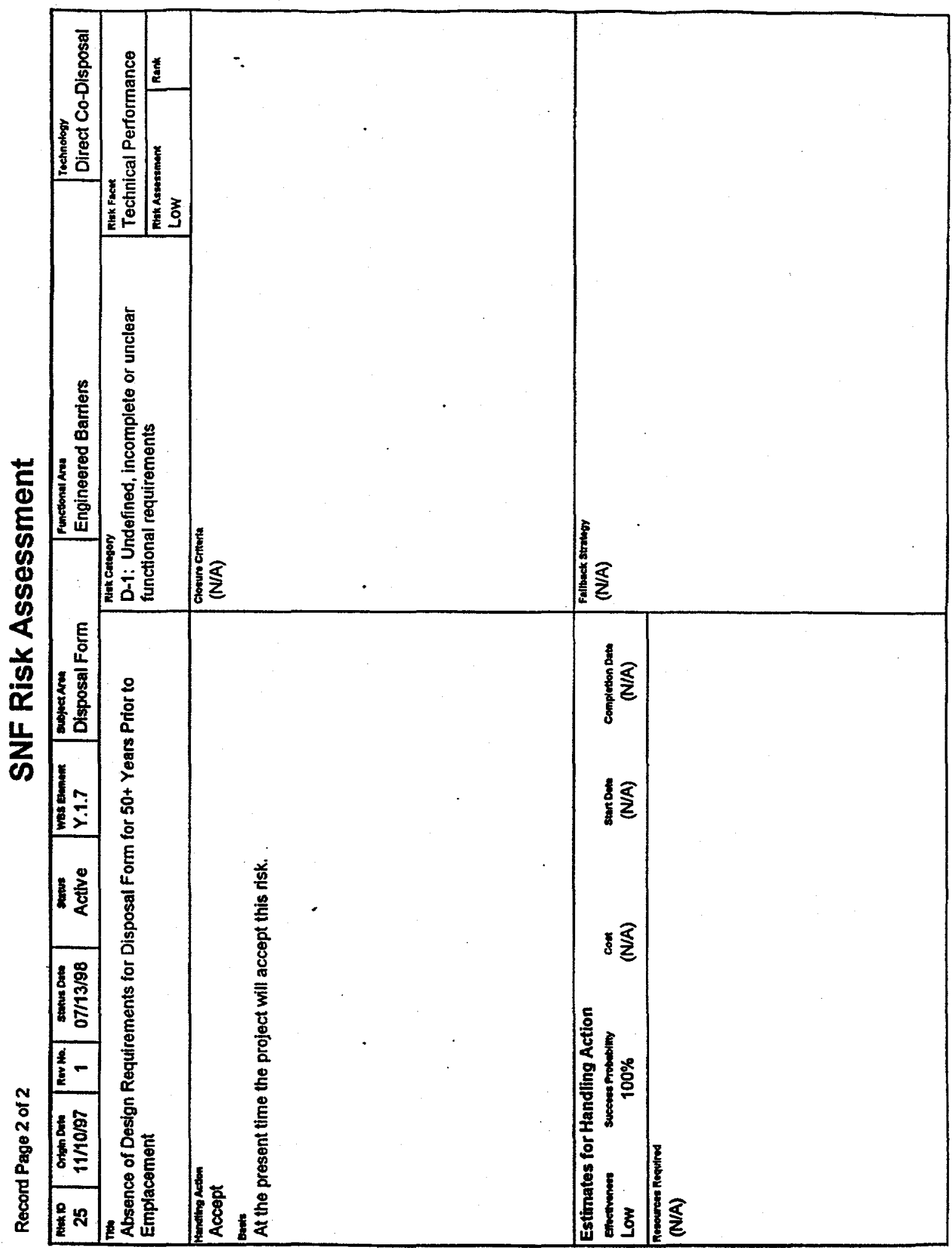




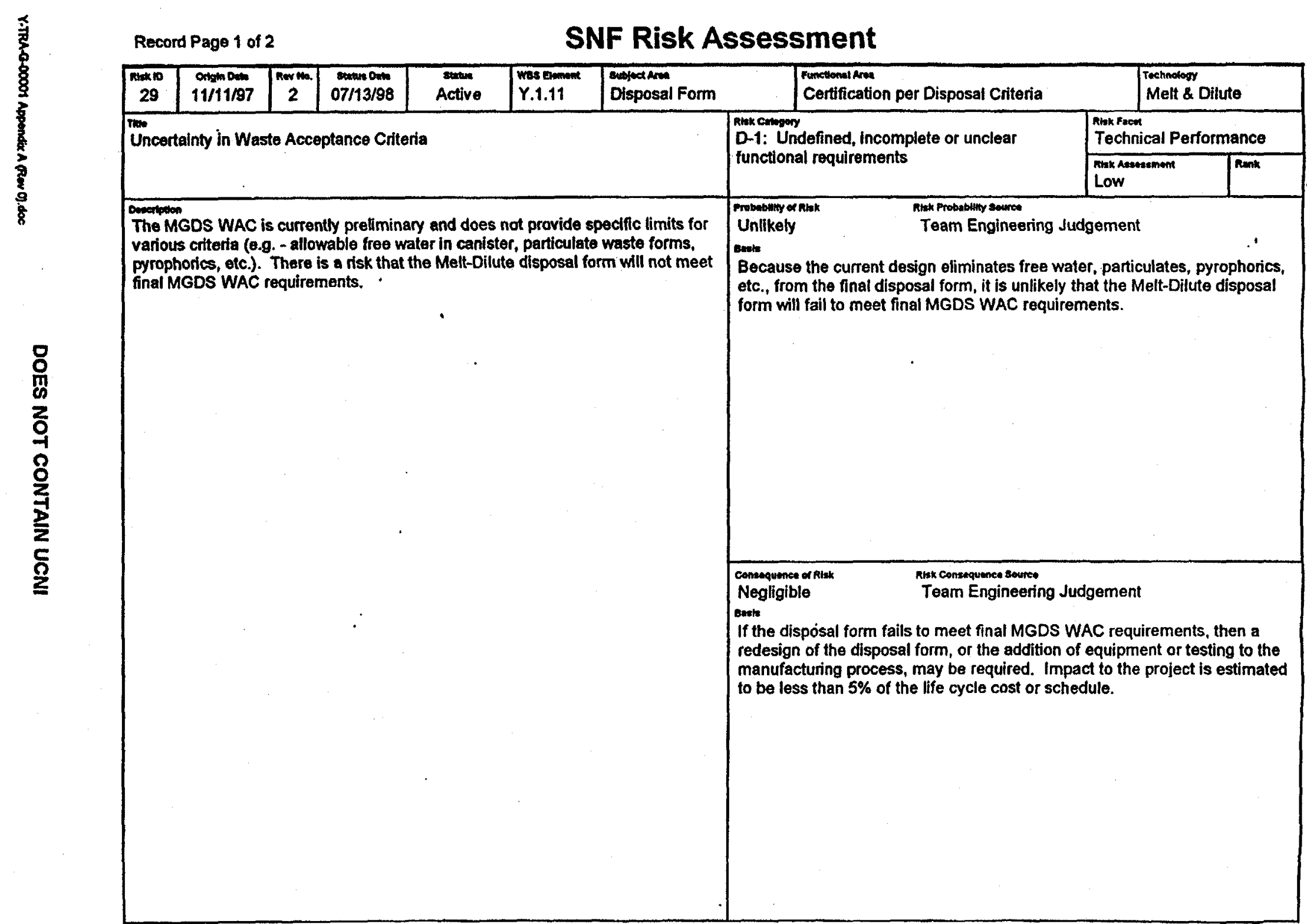




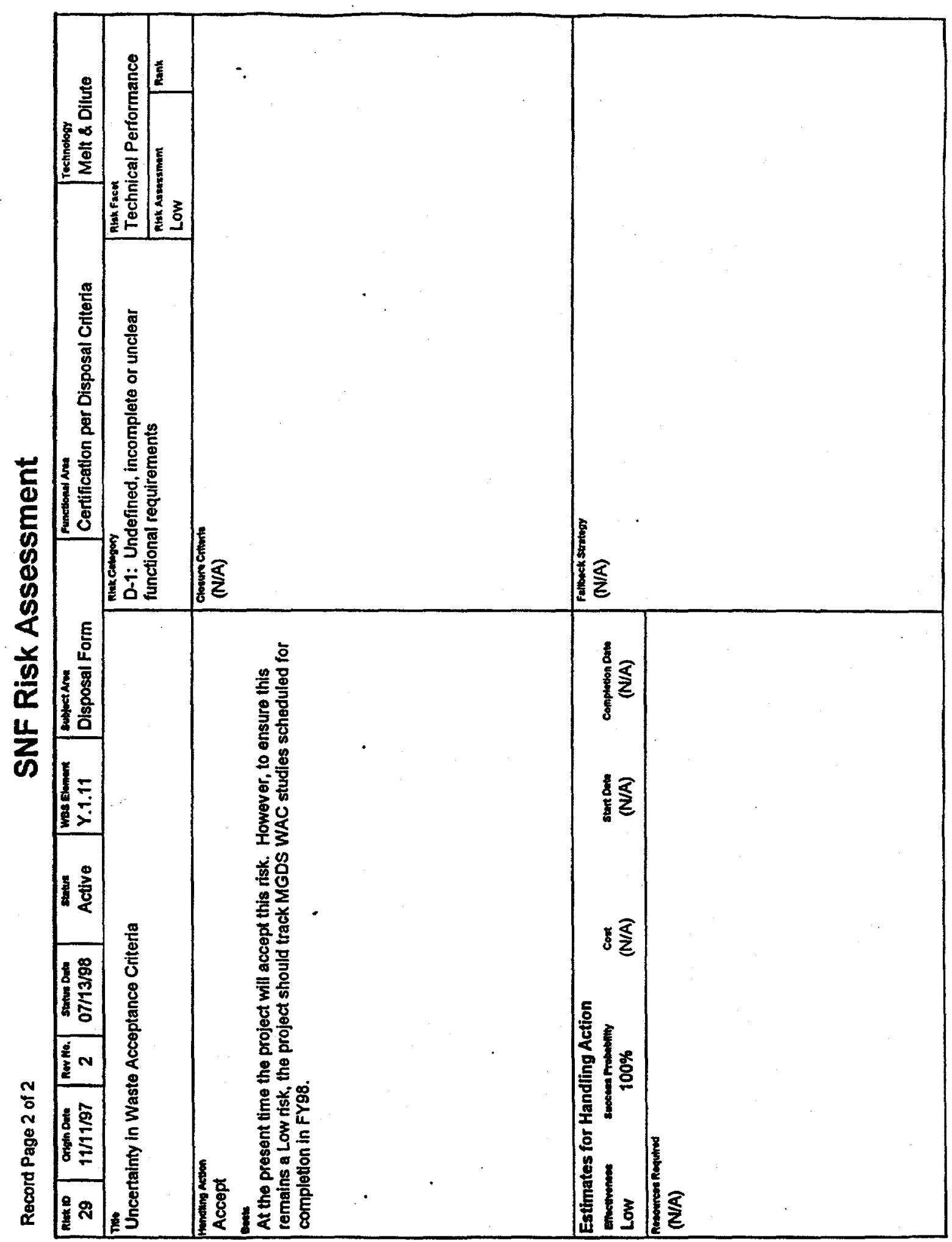




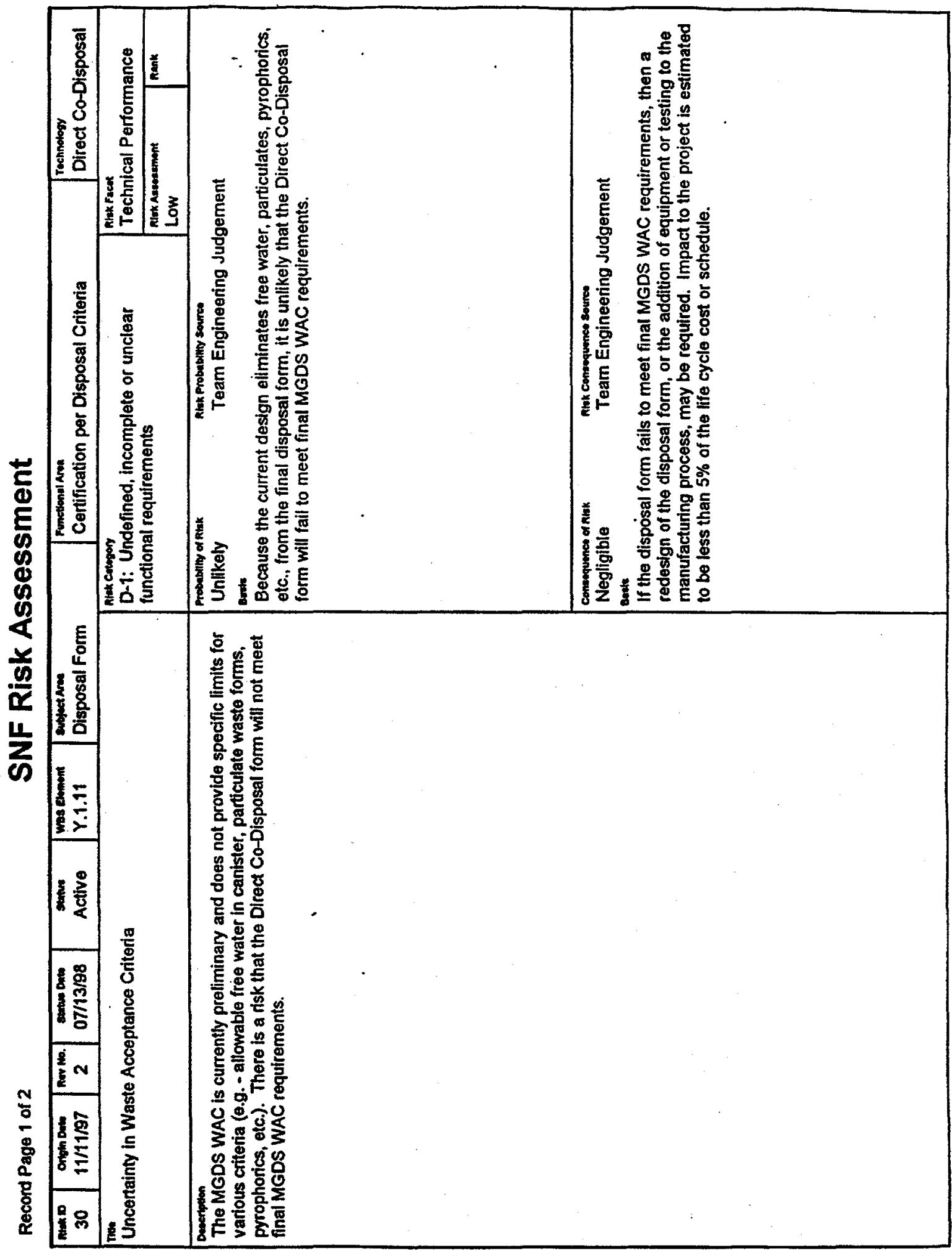




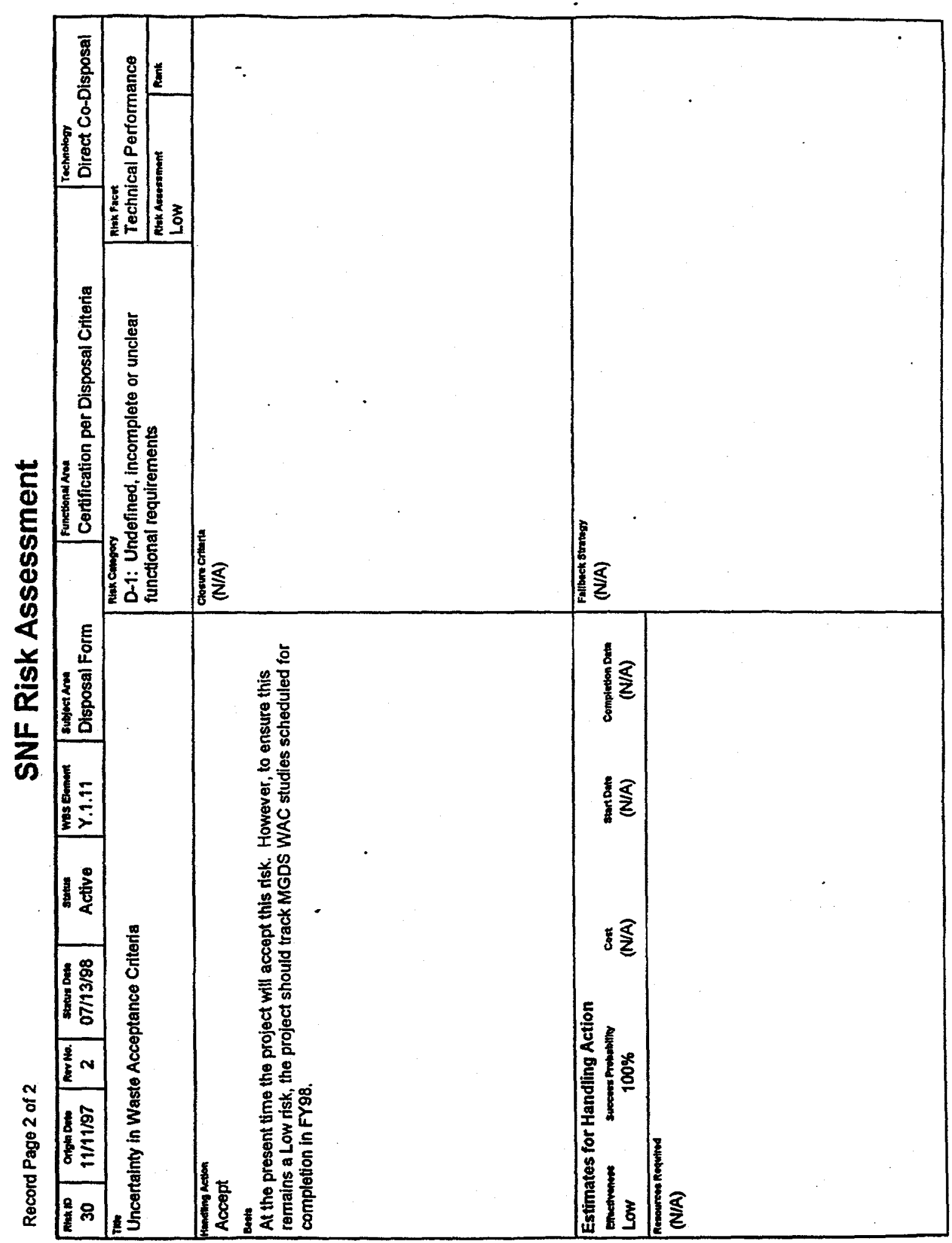




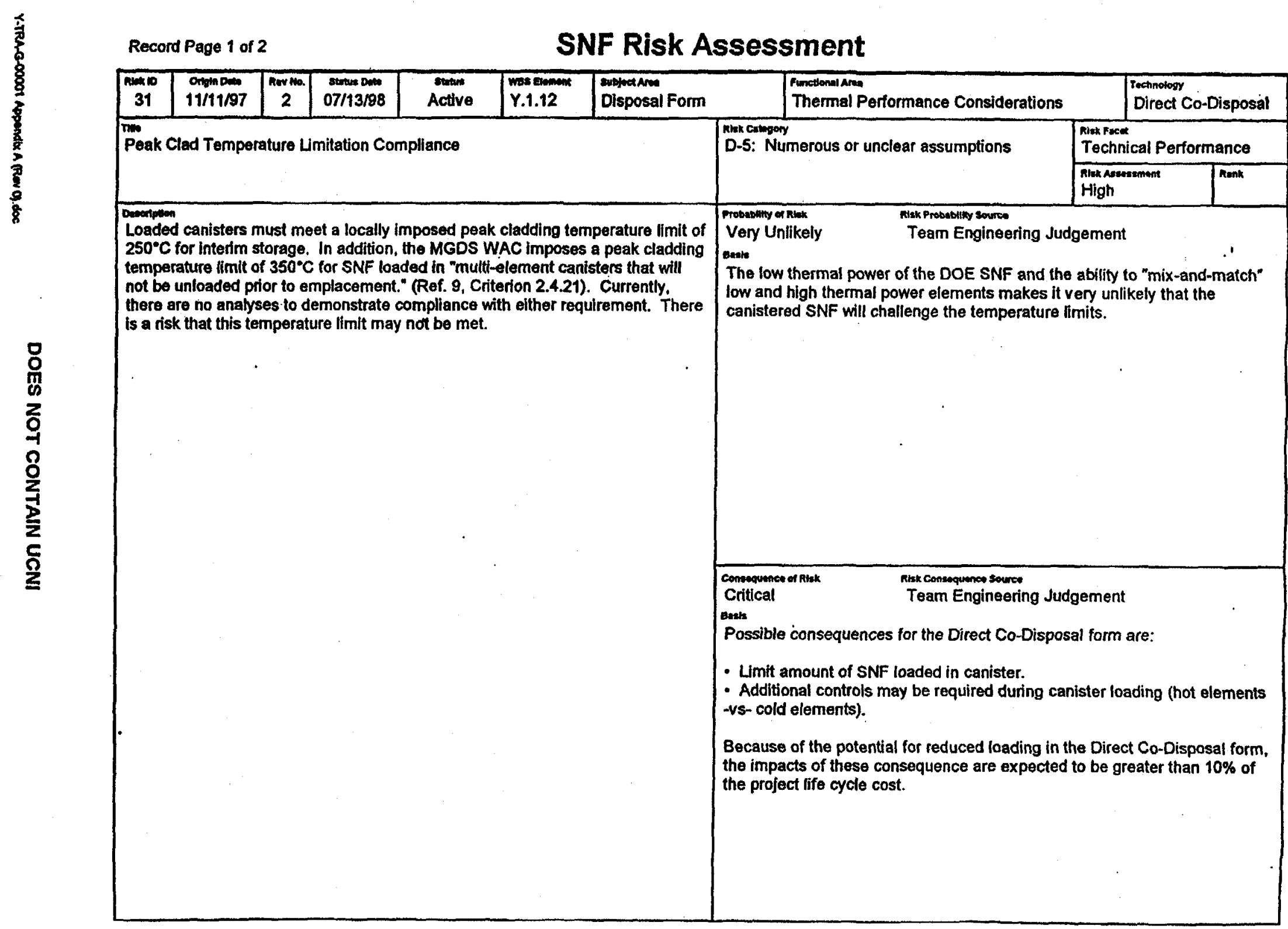




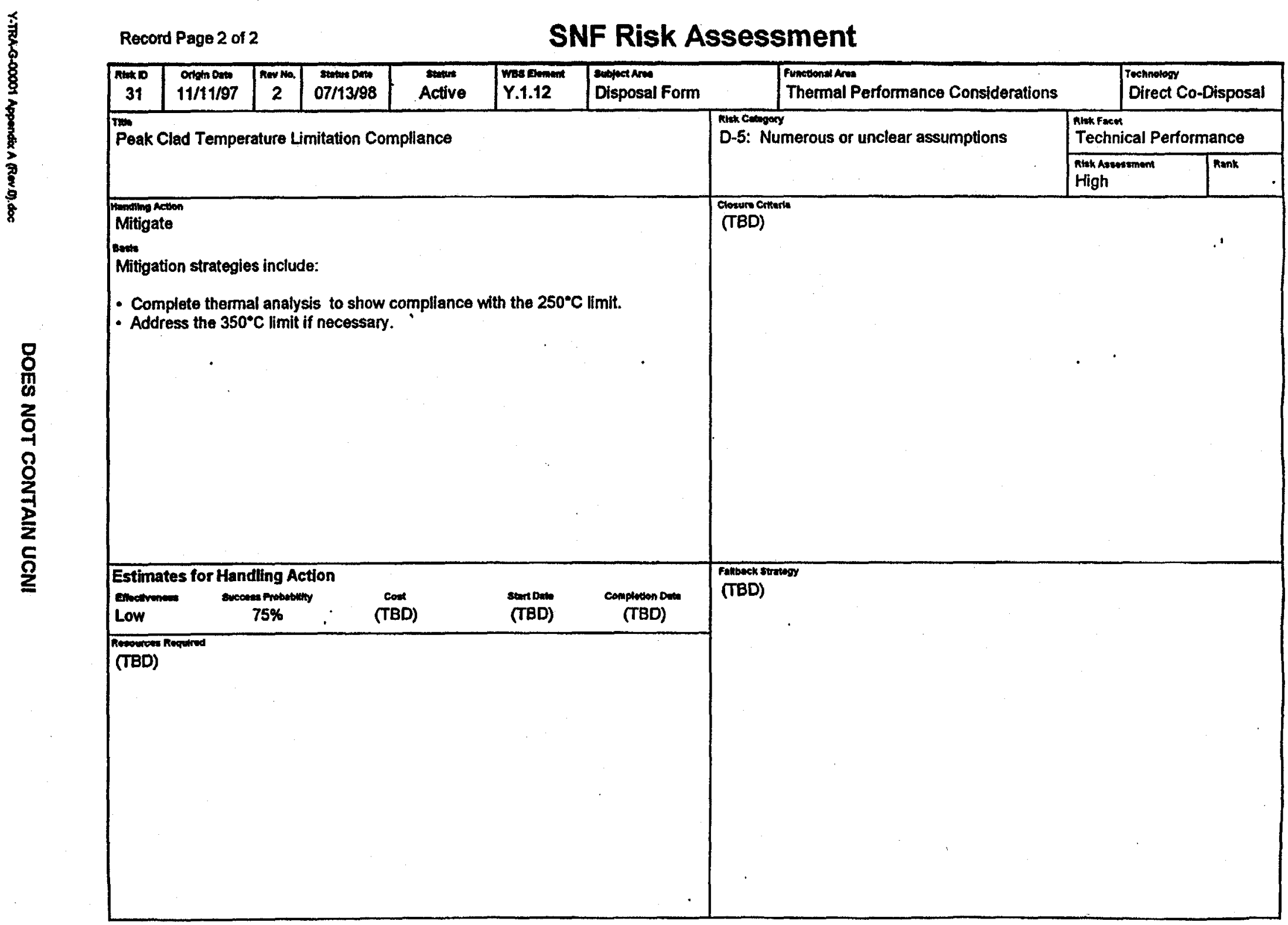




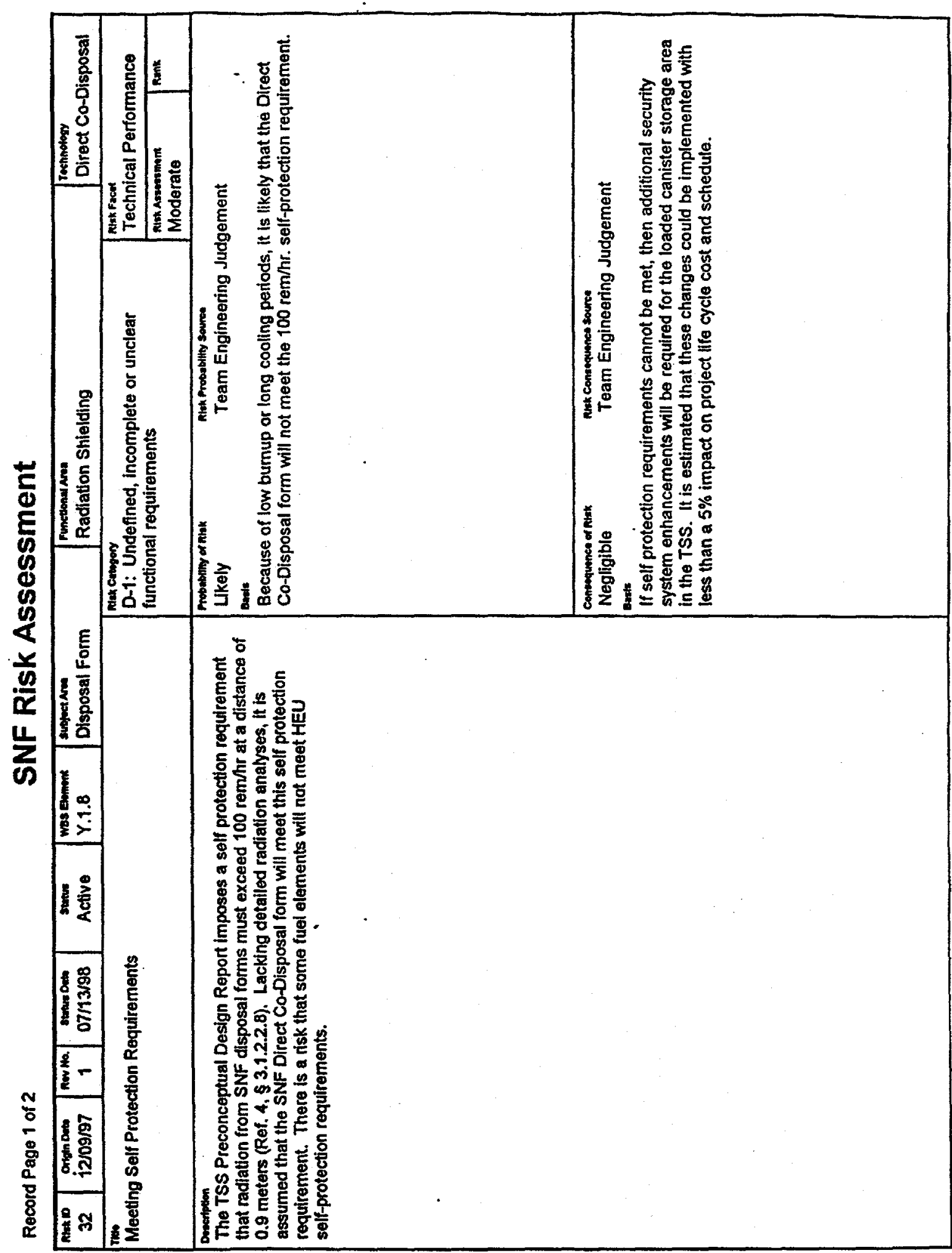




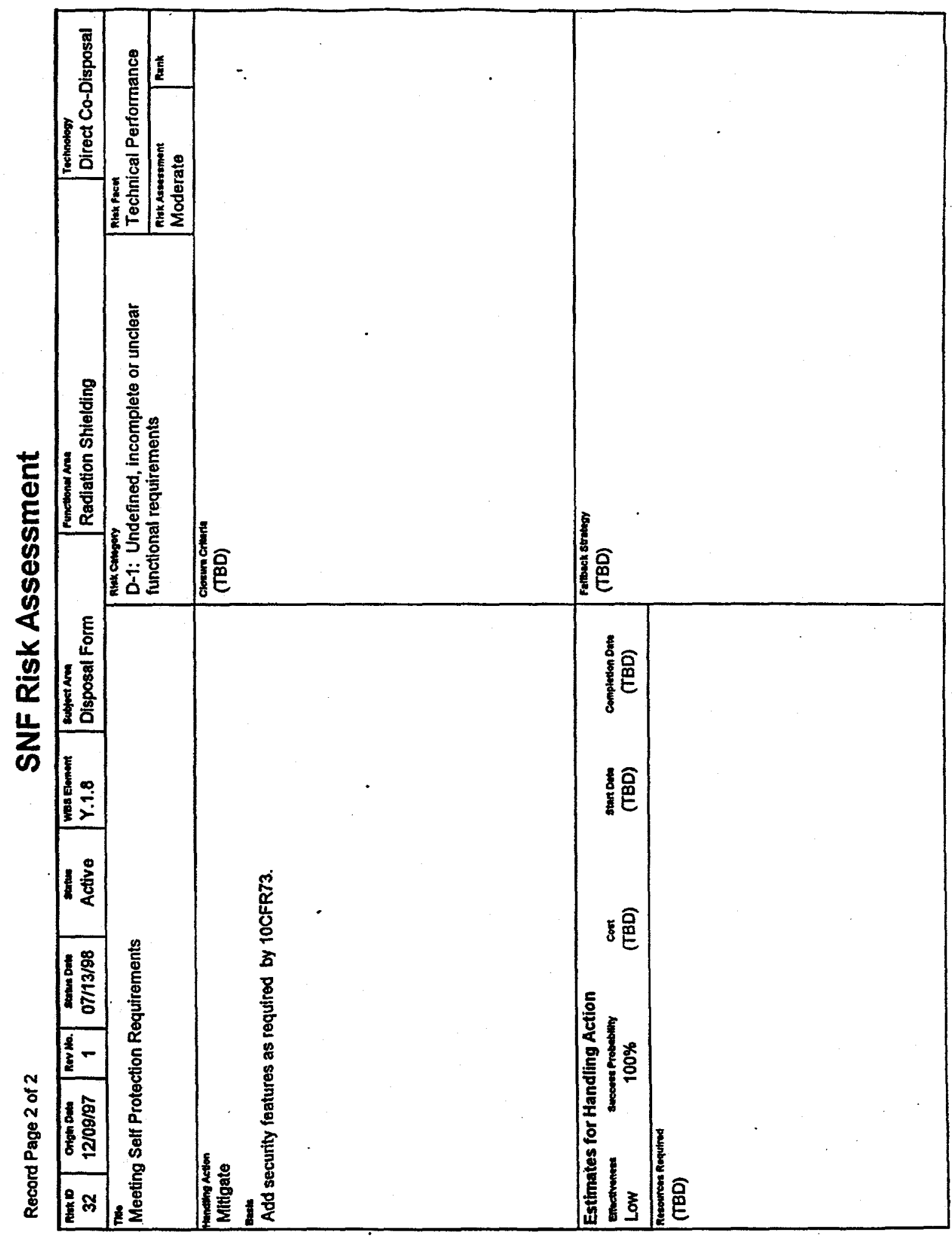




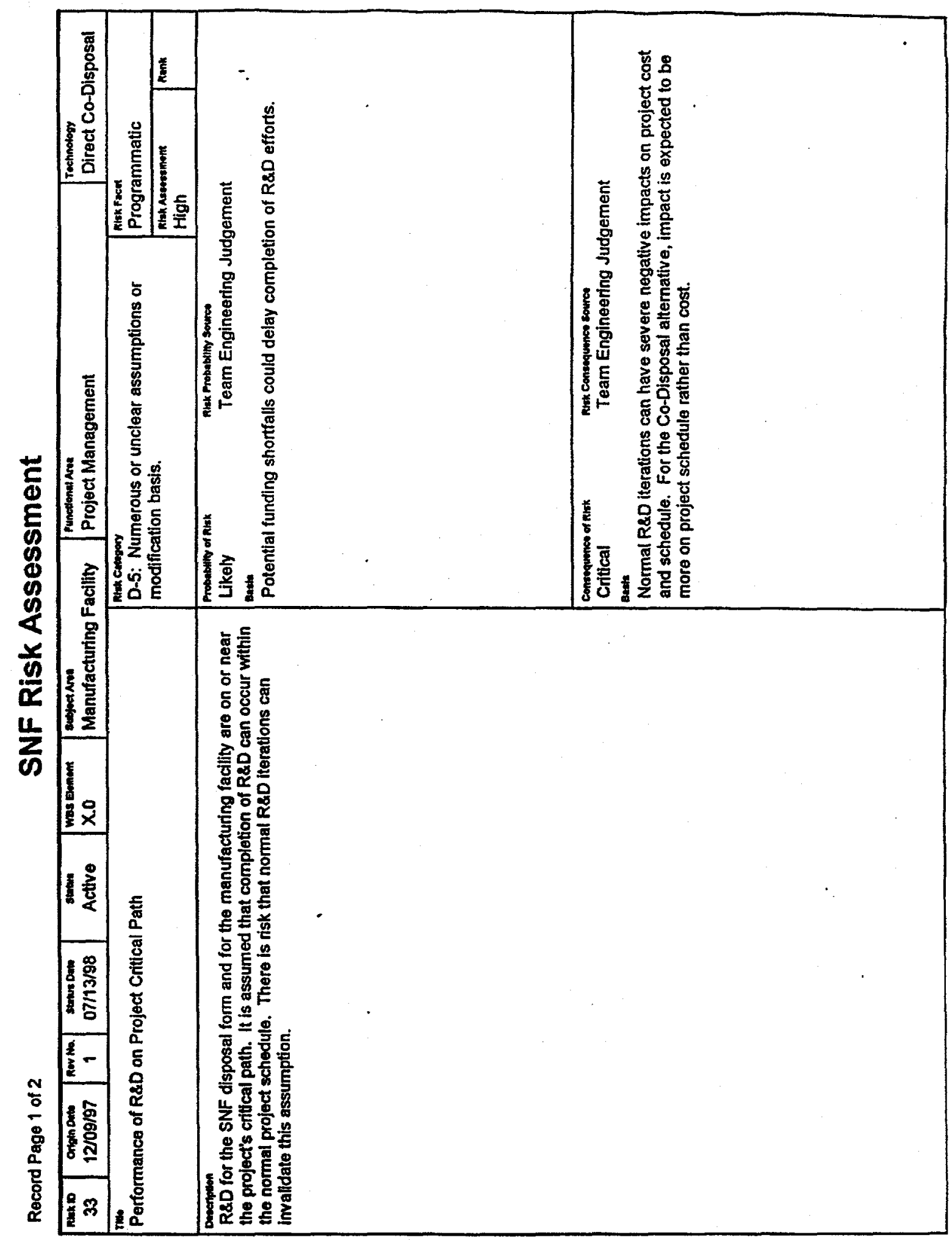




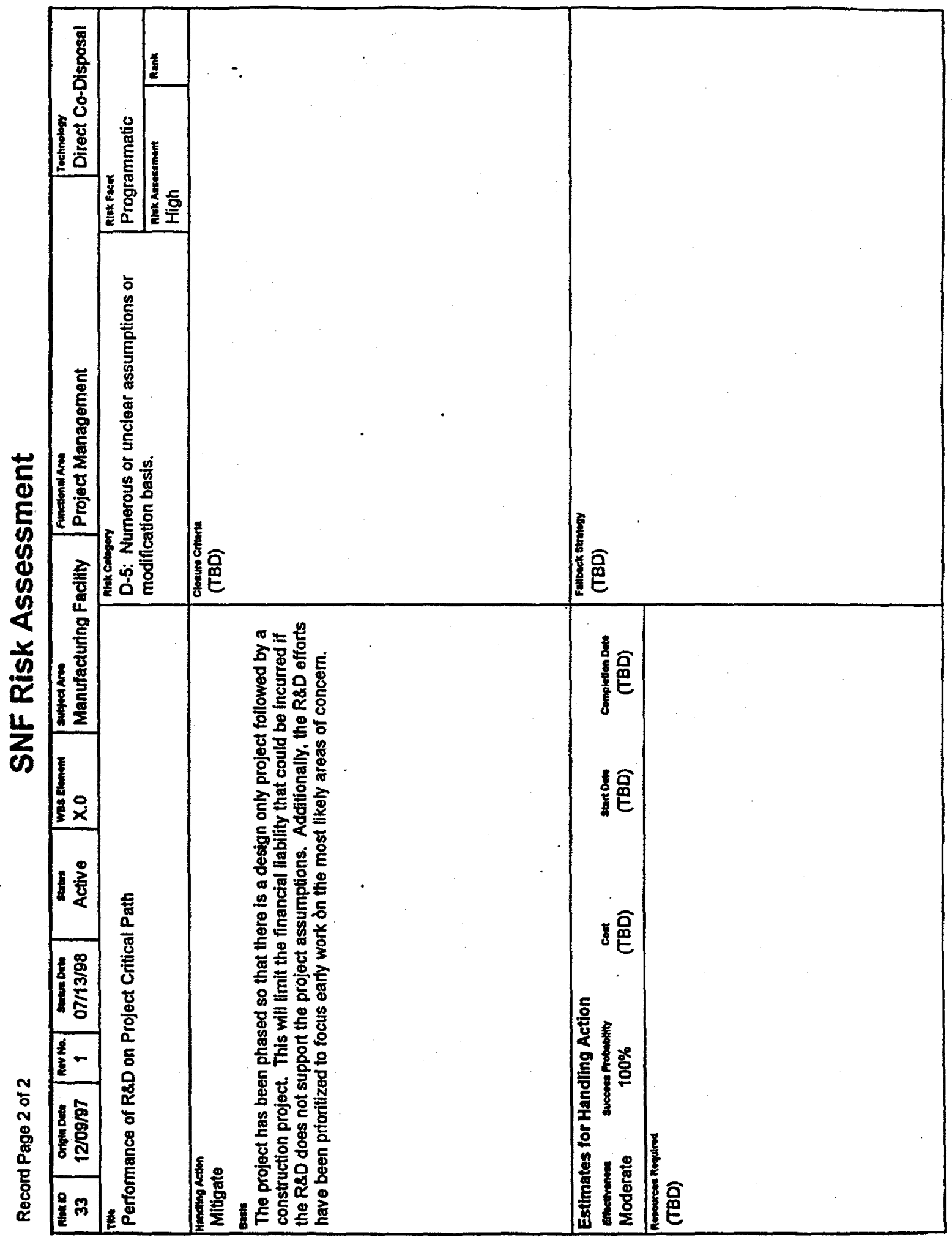




\section{Risk Assessment Database - Deleted Records}

\begin{tabular}{|c|c|c|c|c|c|}
\hline $\begin{array}{l}\text { Risk } \\
\text { ID }\end{array}$ & Title & Technology & $\begin{array}{l}\text { WBS } \\
\text { Element }\end{array}$ & $\begin{array}{l}\text { Subject Area I } \\
\text { Functional Area }\end{array}$ & Page \\
\hline 06 & Disposition of Scrap Waste & Melt \& Dilute & $X .2 .2$ & $\begin{array}{l}\text { Manufacturing Facility } \\
\text { Characterization }\end{array}$ & A-55 \\
\hline 07 & Disposition of Scrap Waste & Direct Co-Disposal & $\times .2 .2$ & $\begin{array}{l}\text { Manufacturing Facility } \\
\text { Characterization }\end{array}$ & A-56 \\
\hline 08 & Identification of LEU Limits & Melt \& Ditute & $\times .2 .4$ & $\begin{array}{l}\text { Manufacturing Facility ! } \\
\text { Packaging }\end{array}$ & A-57 \\
\hline 12 & Non-Fuel Products Received in SNF & Direct Co-Disposal & $\times .2 .4$ & $\begin{array}{l}\text { Manufacturing Facility } \\
\text { Packaging }\end{array}$ & A-58 \\
\hline 15 & $\begin{array}{l}\text { Confinement Versus Containment of Mell-Dilute } \\
\text { Fumace Cell }\end{array}$ & Melt \& Dilute & $\times .2 .12$ & $\begin{array}{l}\text { Manufacturing Facility } \\
\text { Furnace Melt \& Dilute }\end{array}$ & A-59 \\
\hline 19 & $\begin{array}{l}\text { Treating HLW Materials from Off Gas System to } \\
\text { Meet Acceptance Criteria }\end{array}$ & Melt \& Dilute & $\times .2 .13$ & $\begin{array}{l}\text { Manufacturing Facility / } \\
\text { Off Gas System }\end{array}$ & $A-60$ \\
\hline 26 & Imposed Self Protection Requirements & Mell \& Dilute & Ү.1.8 & $\begin{array}{l}\text { Disposal Form / } \\
\text { Radiation Shielding }\end{array}$ & A-61 \\
\hline 27 & Meeting Self Protection Requirements & Melt \& Dilute & Y.1.8 & $\begin{array}{l}\text { Dlsposal Form / } \\
\text { Radiation Shlelding }\end{array}$ & $A-62$ \\
\hline 28 & $\begin{array}{l}\text { Uncertainty Regarding Disposal Form } \\
\text { Classification }\end{array}$ & Melt \& Dilute & Y.1.11 & $\begin{array}{l}\text { Disposal Form / Certification } \\
\text { per Disposal Criteria }\end{array}$ & A-63 \\
\hline
\end{tabular}


Record Page 1 of 1

SNF Risk Assessment

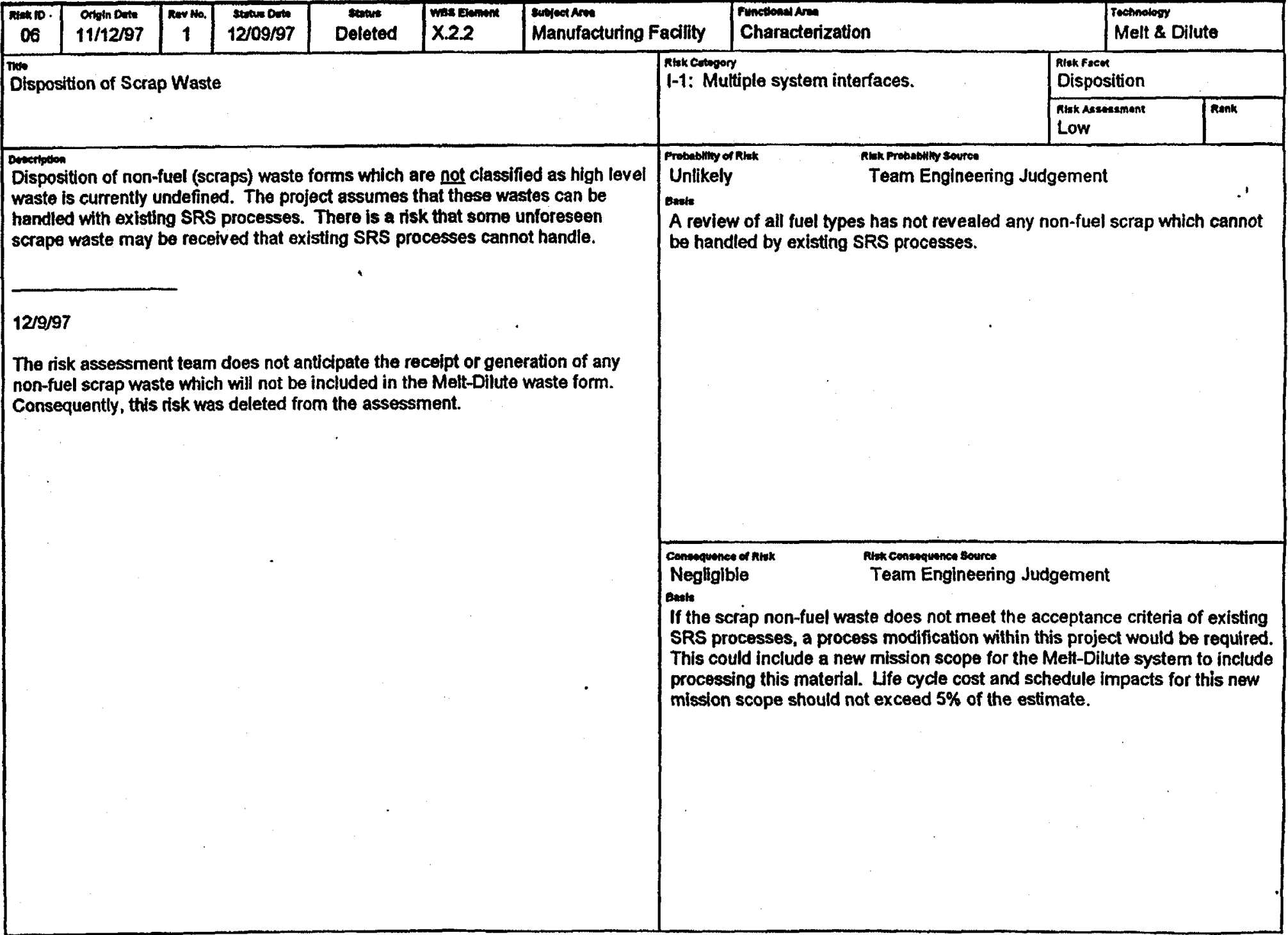




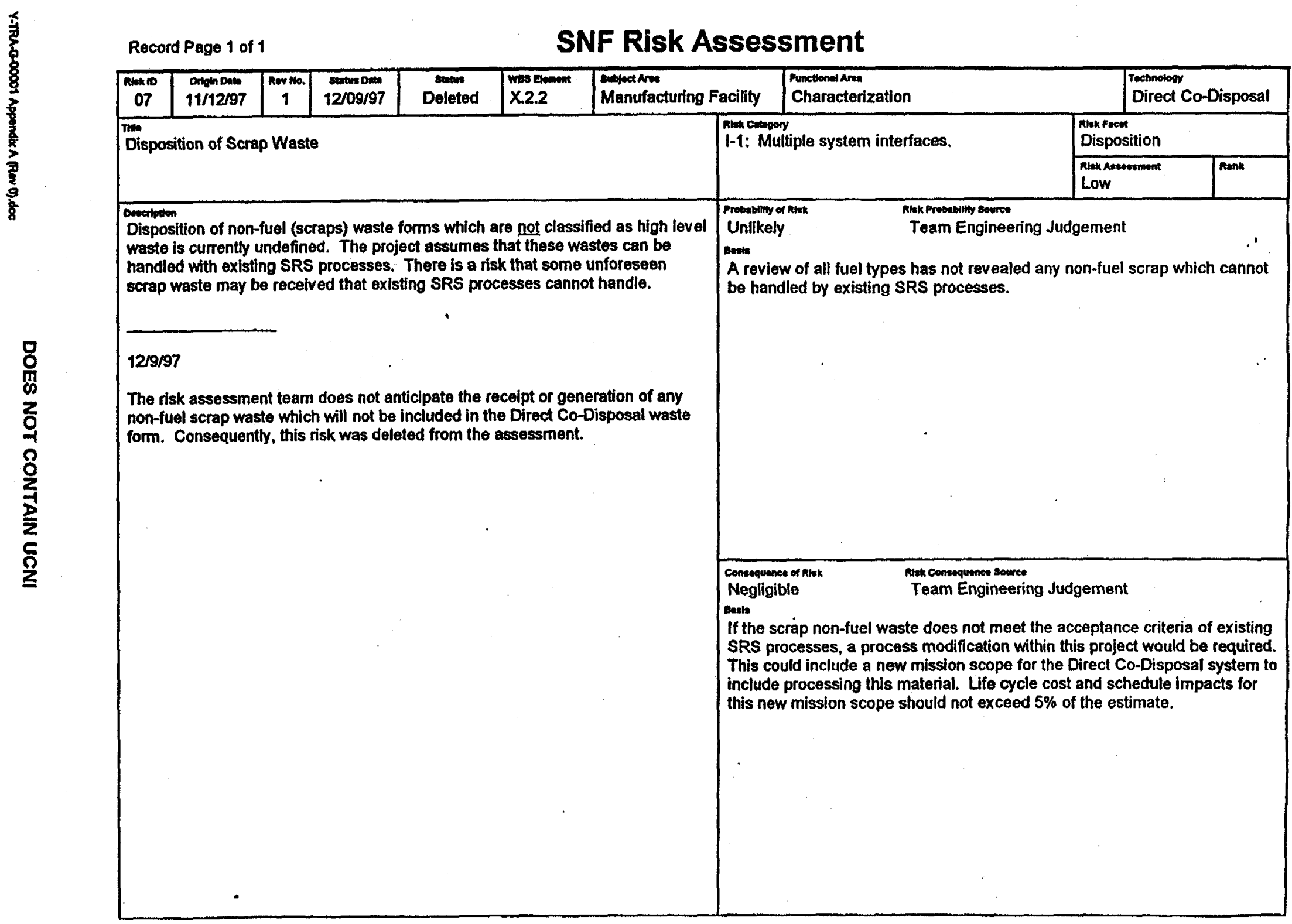




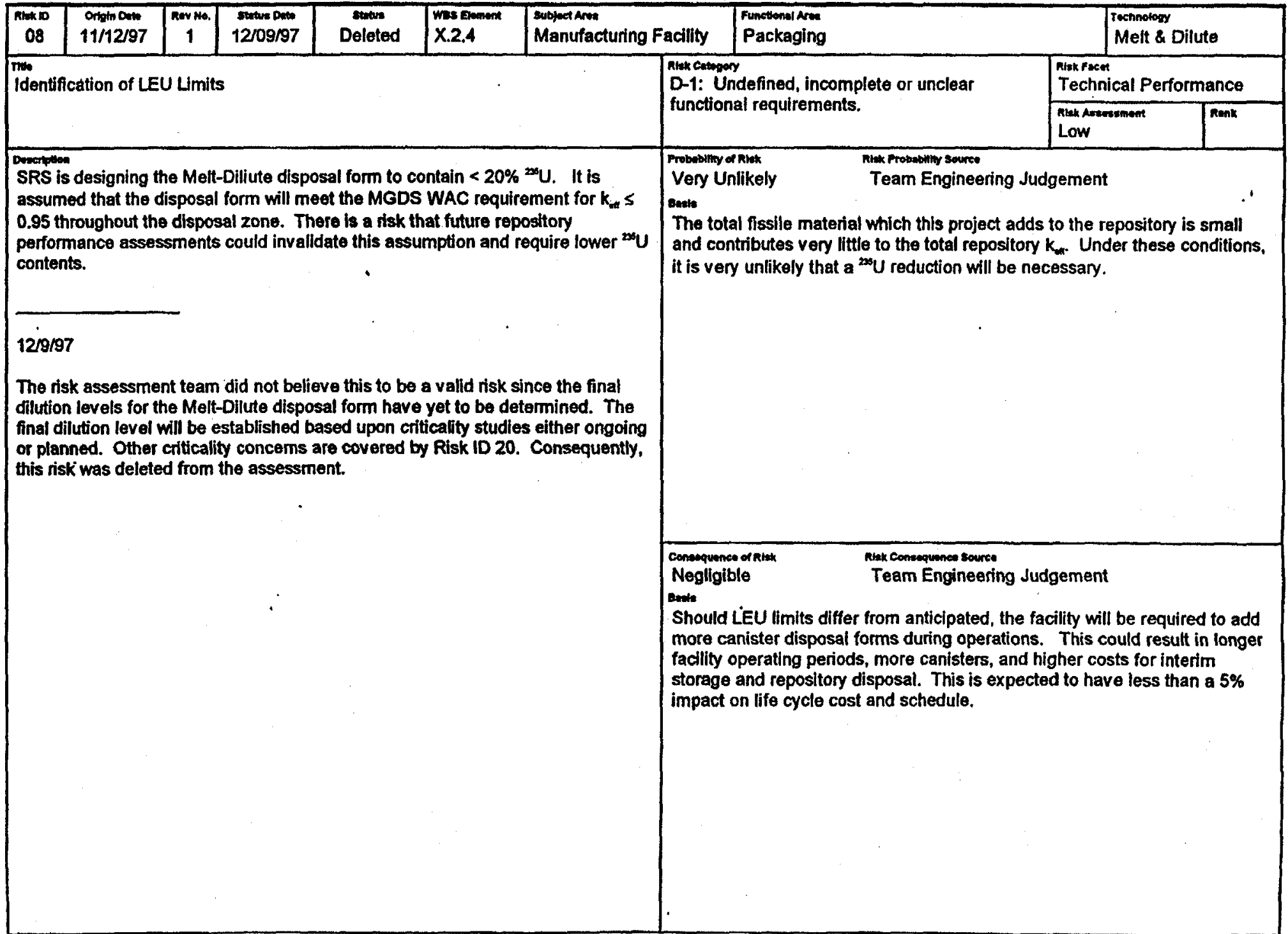




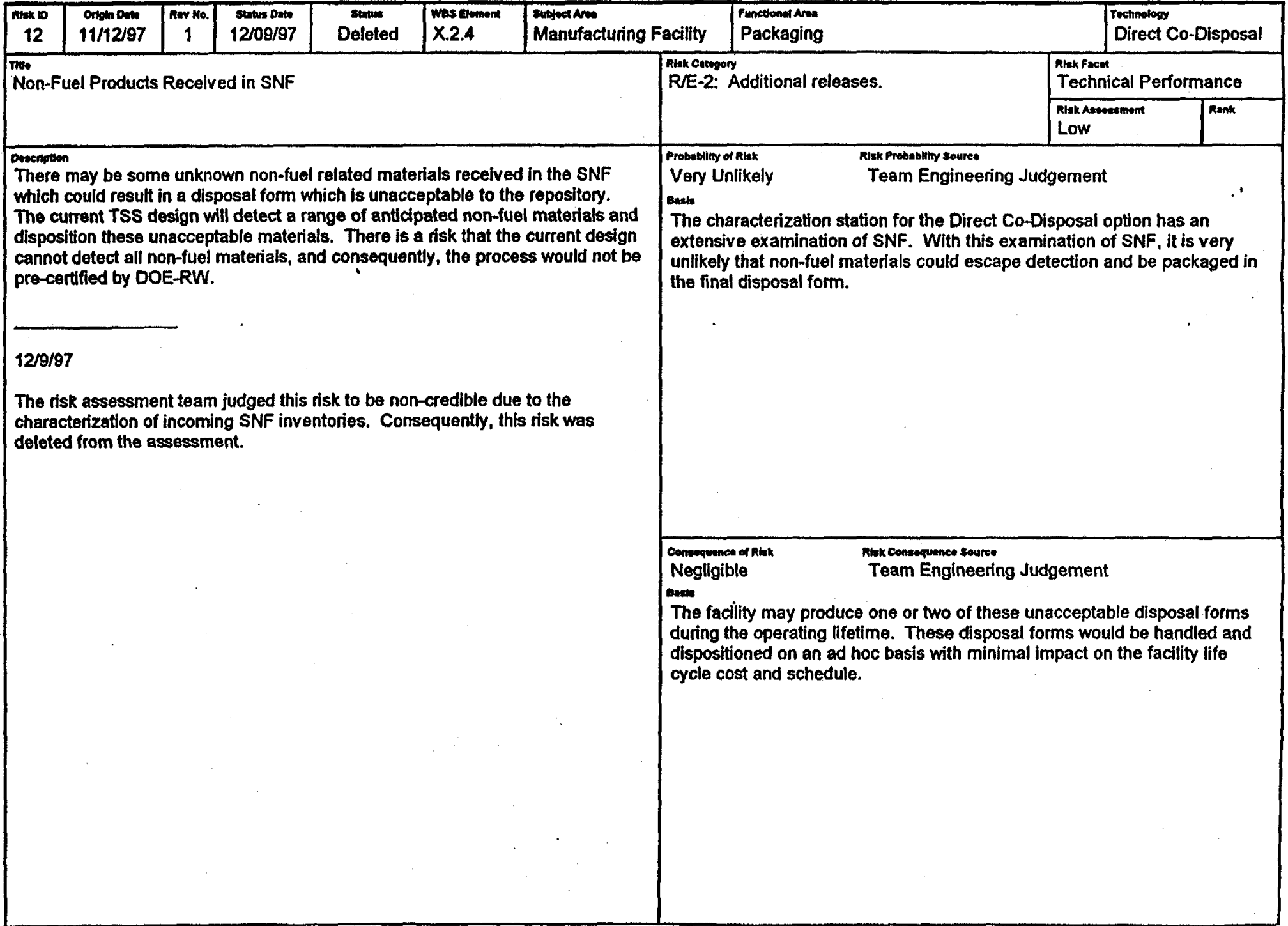




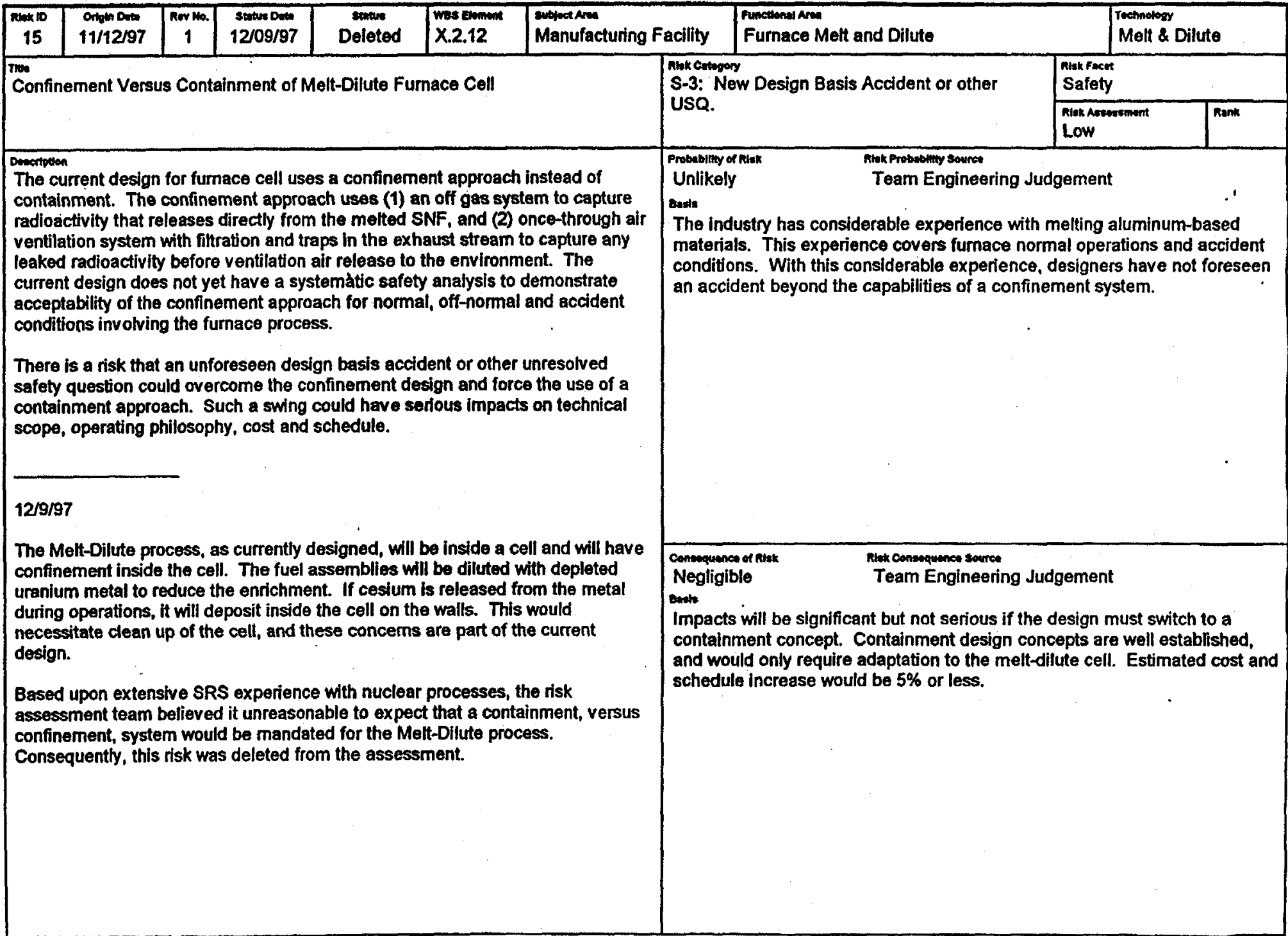




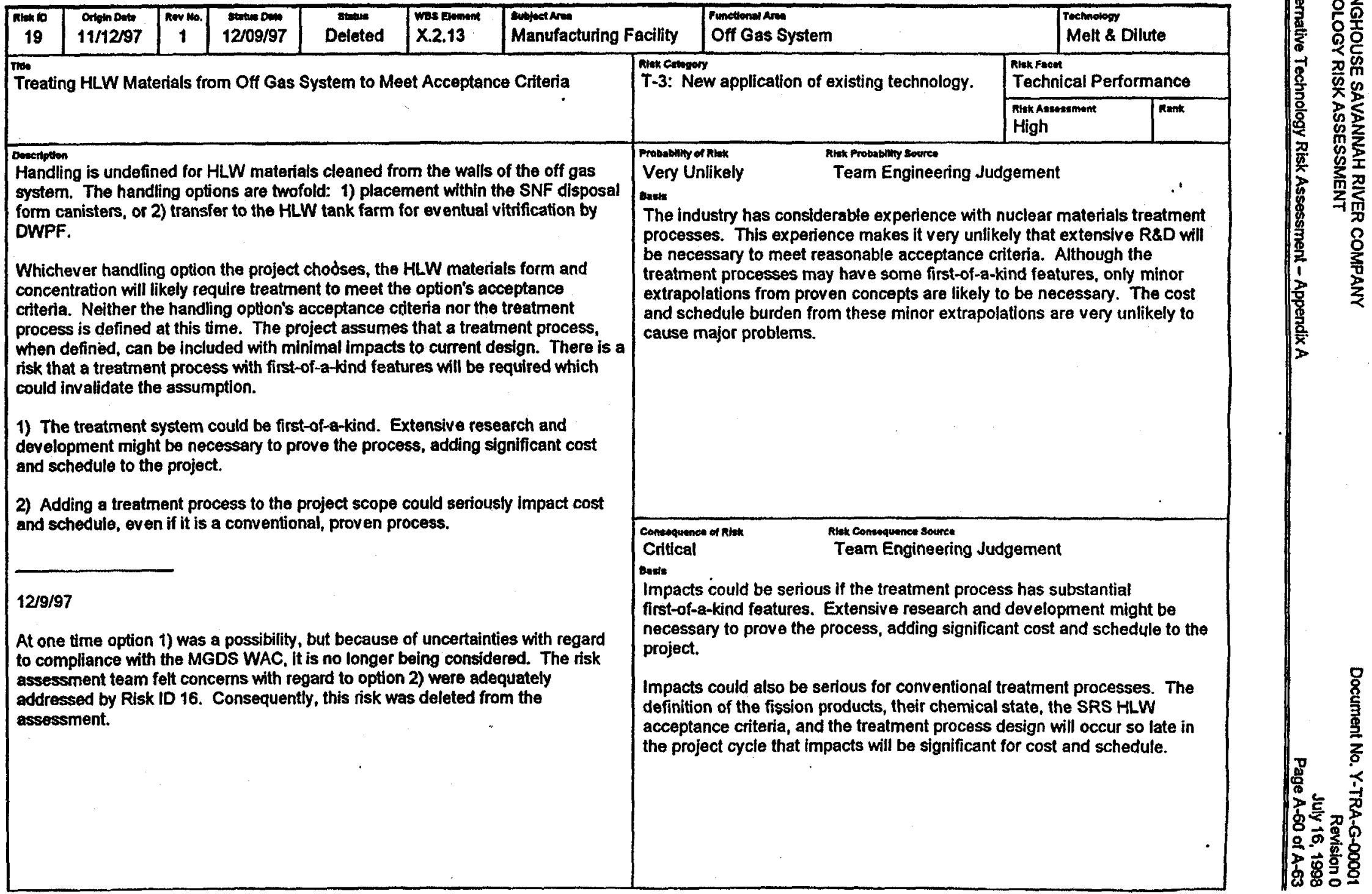


SNF Risk Assessment

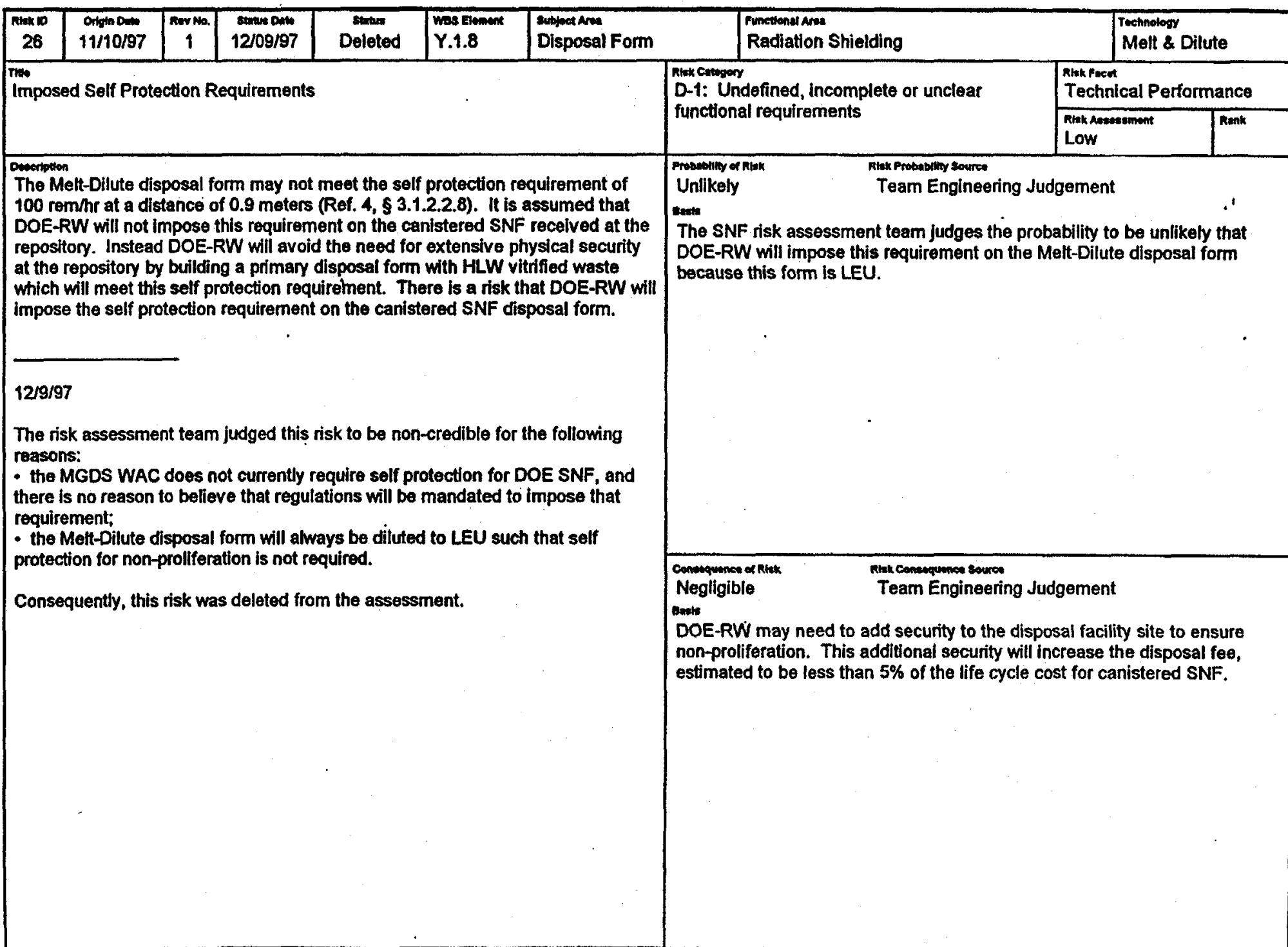




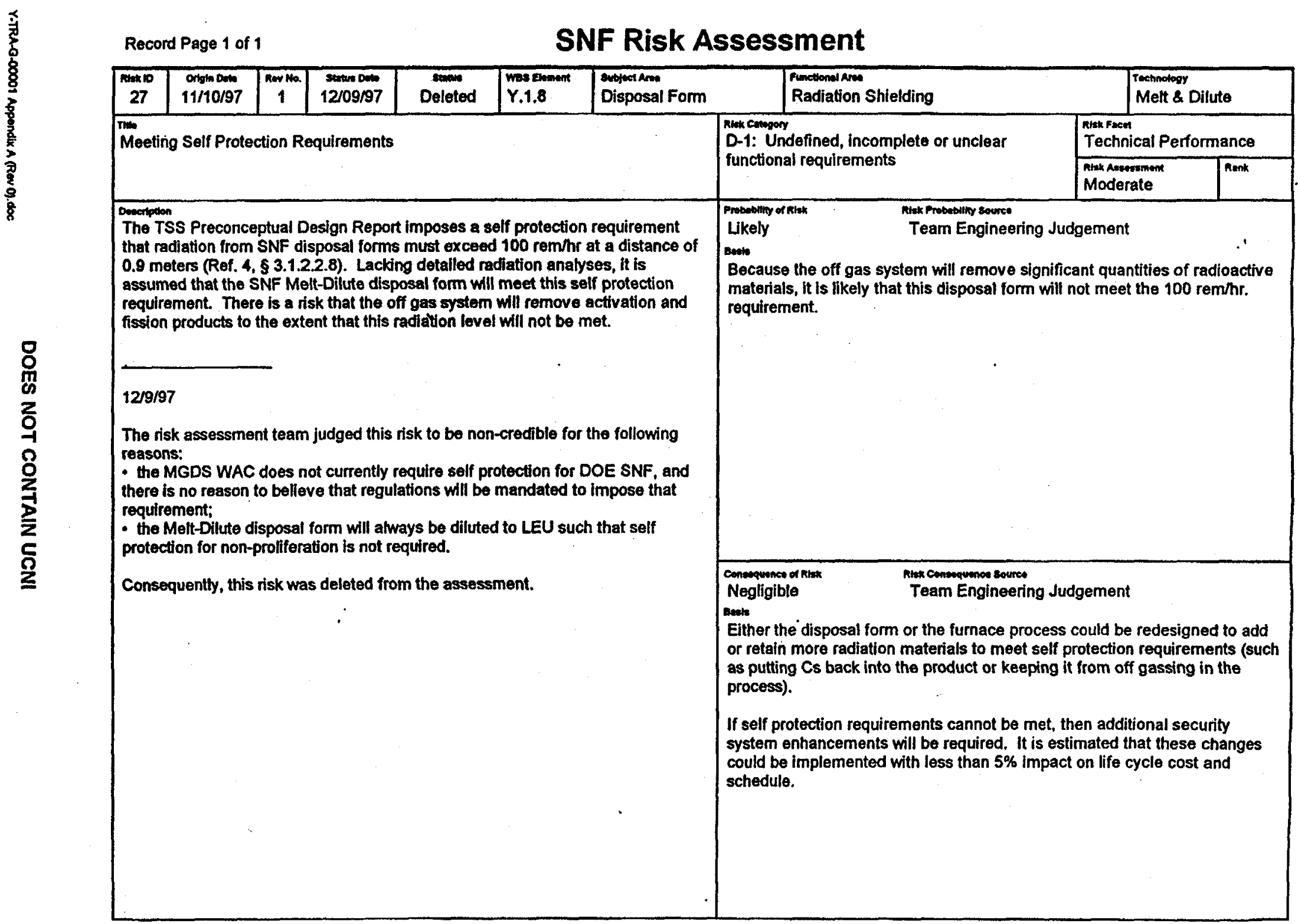




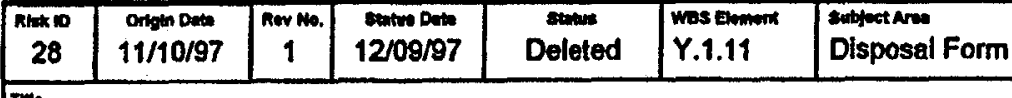

Uncertainty Regarding Disposal Form Classification

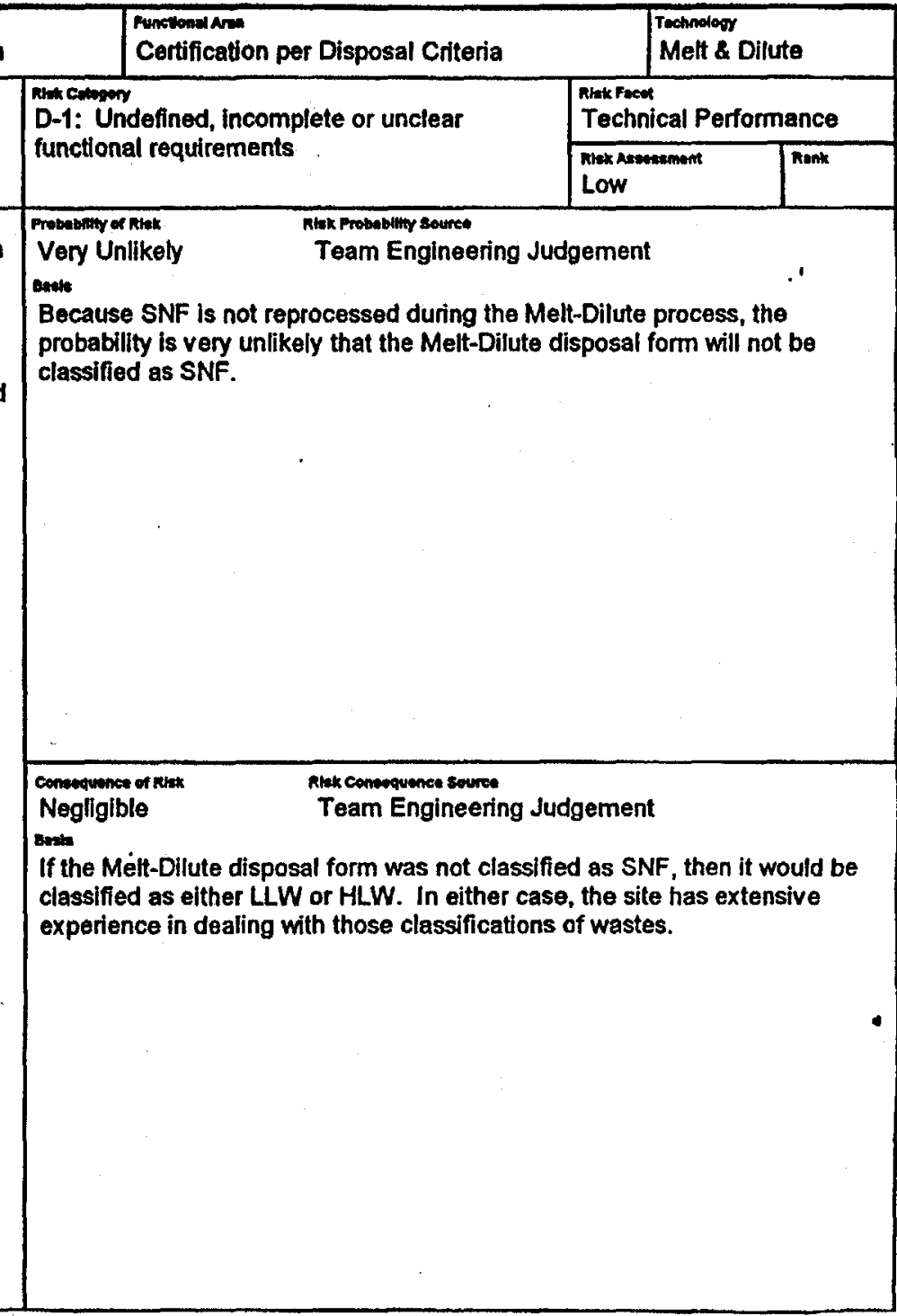

According to the MGDS WAC, SNF is defined as "...fuel that has been withdrawn from a nuclear reactor following irradiation, the constituent elements of which from a nuclear reactor following irradiation, the constituent elements of which
have not been separated by reprocessing." The design approach assumes that the Melt-Dilute disposal form will still be classified as SNF, and that the certification criteria for SNF will apply. There is a isk that the Melt-Dilute

disposal form will not be classified as SNF after it has gone through the proposed disposal form procass.

If the disposal form is not classified as SNF, but is instead classified as HLW, then it is assumed that existing ASTM standards and the MGDS WAC for HLW apply, and that those standards and criteria are no more rigorous than those for SNF or vitrified HEW. There is a contingent risk that if the disposal form is classified as non-vitrified HLW, the Melt-Dilute process may have to be changed to accommodate more rigorous standards and/or criteria.

$12 / 9 / 97$

The risk assessment team judged this risk to be non-credible since the Melt-Dilute process does not alter the constituents of the U-AI SNF.

Consequently, this risk was deleted from the assessment (Ref. Assumption 3). 